\title{
Mammals of Utah
}

By CLAUDE T. BARNES

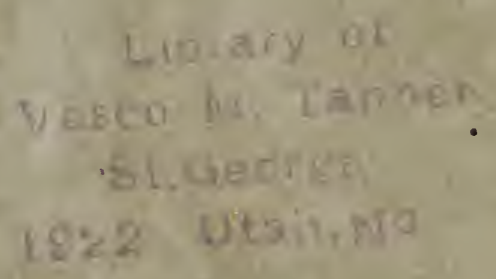




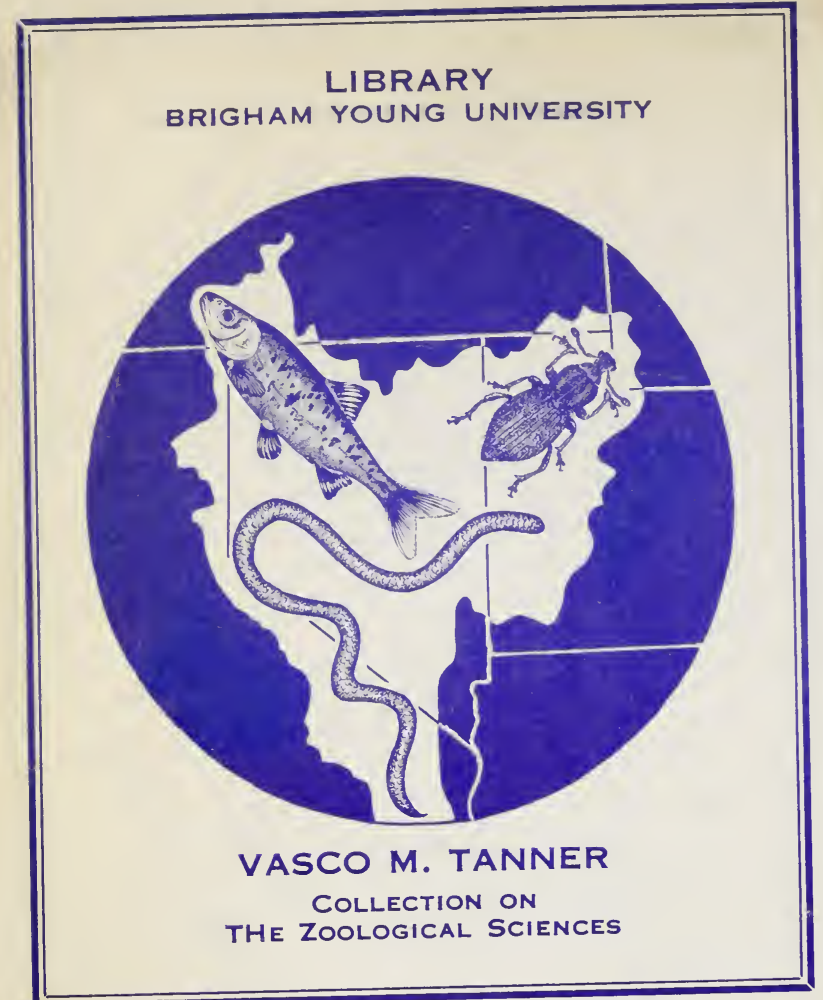

BEAN MUSEUM LIBRARY 


\section{By CLAUDE T. BARNES}

Member American Society of Mammalogists, Member Biological Society of Washington, Associate Member American Ornithologists' Union, Co-author "Western Natural Resources," "Forest Groves and Canyon Streams," Member of the American Association for the Advancement of Science, etc.

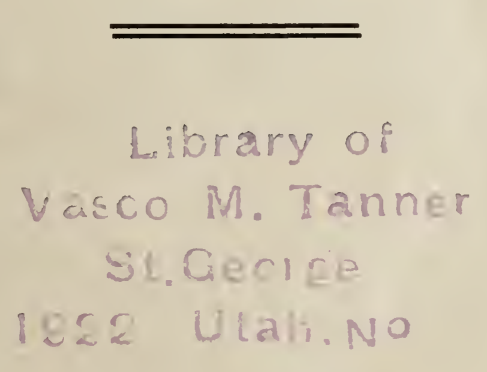

Bulletin of the

UNIVERSITY OF UTAH

SALT LAKE CITY

UTAH

Inland Printing Company, Kaysville, Utah 


\section{F O R E W O R D}

Three things have induced the author to enter upon the preparation of a work on the mammals of Utah: the unavailable nature of the scattered data on our wild animals; the constantly increasing public interest in nature generally; and the pleasurableness of the undertaking as a personal diversion. The aim has been to furnish the reader a dependable list of our mammals with accurate descriptions and brief notes on their habits and economic status.

Every available source of information has been utilized; and, in some instances, even where statements reflect the observations of the author, the work has been strengthened by the citation of numerous well-known authorities. Of course even there the author has met divergent views: the tendency, on the one side, to name new races based on slight variations and the disinclination, on the other side, to recognize forms indeterminable in the living animal. Every effort has been made, however, to cover the ground completely.

Occasionally some incident has lightened the work of investigation, such as, for instance, the report of the presence of "ibex," "chamois," and mountain goats, or the alarming views of some informants on the habits of several larger mammals.

It is astonishing the number of gaps yet to be bridged in our knowledge of the habits of our mammals generally; and it is the sincere hope of the author that this work will to some degree encourage those observations afield which alone can overcome such difficulties.

In the preparation of the synonomy the works of Dr. Elliot have been chiefly relied upon; and the descriptions have, as far as possible, been taken from original sources.

The author is deeply indebted to Dr. William T. Hornaday of New York City for reading the manuscript and for the making of many helpful suggestions; to Dr. C. Hart Merriam of Washington, D. C., for furnishing otherwise unavailable publications from his private library and for settling several knotty problems; to Dr. N. Miller of the University of Utah for his kindly counsel in many important matters ; and to Dr. John A. Widtsoe, former President of the University of Utah, without whose encouragement the work would never have been undertaken.

CLAUDE T. BARNES, Salt Lake City, Utah 
Digitized by the Internet Archive in 2014 


\section{N T R O D U C T I O N}

Constituting the highest class of vertebrates, the Mammalia includes man and all other warm-blooded animals that nourish their young with milk. They are (except the monotremes) viviparous; that is, their young are brought forth alive as distinguished from existence as eggs. In all except the cetaceans the skin is covered with hair, which is the outgrowth of the epidermis only and contains neither blood vessels nor nerves. The class possesses, moreover, these noticeable characters: "mammary glands; the mandible articulating directly with the squamosal; the ankle joint when present crurotarsal; a chain of small separate ear bones; brain with four optic lobes; a muscular diaphragm separating the heart and lungs from the abdominal cavity; a left aortic arch only; and red blood corpuscles without nuclei (except in the fetus)."

Some mammals such as whales, manatees and seals, are aquatic; the bats are aerial; but most are either terrestrial or arboreal. A semi-arid, mountainous, inland region like Utah is favorable to only the terrestrial and aerial forms.

As probably the highest aim of knowledge is the welfare of mankind, the ascertainment of the economic status of our various wild mammals must at all times be of primary importance. As closely related species and even genera may have almost identical food habits, it is deemed advisable to give here a resume under broad groups of the habits of our mammals as they benefit or injure man.

Of the Ungulata, or hoofed quadrupeds, elk, mule, deer, moose, mountain sheep and prong-horned antelopes, subsist on vegetation gathered in wild, uncultivated regions; and hence are in no sense harmful. When under protective laws that happy time is reached when the white-tailed deer or even the elk become so tame and numerous that they do eat cultivated crops to some extent (a condition which actually obtains in some of the most thickly populated Eastern states) prompt reimbursement can and should be made by the state legislature. The food value of these animals is so high that the most casual observer should not only appreciate it but also actively engage in encouraging the increase of animals valuable both as food and as a constant stimulus to that physical recreation which the average American too truly needs. It is certain that if the leadership of such men as Dr. William T. Hornaday (the world renowned champion of wild life) is followed and 
Utah's present incomparably favorable laws are kept in force, this state will one time have such a plentiful supply of game that every boy will have occasion to thank the wisdom of his forefathers. It is a matter of great satisfaction to the author, that the 1919 session of the Utah Legislature had to consider a claim for crop-damage done by elk, the first bill of its kind and a direct result of recent protective legislation.

Of the Glires or rodents, our two chickarees, being true squirrels, live on nuts and seeds, only occasionally doing mischief. Our nine chipmunks eat berries, insects and seeds; and though in some instances they do some damage to grain fields, they probably on the whole do more good than harm. The dozen species of ground squirrels or spermophiles (Citellus) found within the state, destroy many grasshoppers, beetles, flies, larvae, and the buds of harmful plants; but wherever numerous they so ravage the grain fields that they undoubtedly should be exterminated. Though the prairie dogs usually occupy ground so barren as to be useless to the farmer, their fondness for green grasses, cabbages, cantelopes and such produce sometimes results in encroachment upon and damage to near-by cultivated tracts. Woodchucks, living chiefly on such grass and clovers as grow in their high mountain retreats, are more interesting than mischievous.

Beavers subsist principally on the bark of such trees as the aspen, with the addition in summer of many kinds of vegetation, berries, pond-lily roots and marsh grass, and where numerous they occasionally damage the agriculturist and horticulturist. Ample provision is, however, made in the Utah law for the depletion of their numbers in certain instances, under the supervision of the Game Commissioner; hence, when the great value of their pelts is considered they well merit the general protection they receive. Eventually they will become a valuable asset to the state, as they have increased surprisingly the past few years.

So numerous have rats become about the homes of Salt Lake City that the situation is alarming to those who know of the plagues that these disease-carrying pests have caused elsewhere. Immediate steps must be taken towards their extermination. Every householder should at once write to the U. S. Department of Agriculture, Washington, D. C., for a copy of Farmers' Bulletin 369, "How to Destroy Rats." Furthermore those people who understand the use of ferrets should as soon as possible introduce these animals, which are very efficient rat-killers. 
Most of the mice of the genus Onychomys eat seeds and grass only when hungry and their customary bill of fare includes such a wide variety of insects that they well deserve the name "grasshopper mice." The field mice (Peromyscus) include nuts, seeds and berries as well as a few insects in their fare, being not especially destructive; but the harvest mice are distinctly harmful.

The wood rats (Neotoma) make vast stores of grass, fruit, bulbs, bark, seeds, nuts and fungi; but being mostly in rocky mountainous regions they in the aggregate do little appreciable damage. though instances are not wanting of their having girdled shrubs or stolen stored grain.

The various voles of the genus Microtus, feeding on grass, bark, seeds, grain and some insects, are very destructive when numerous. In these days it is incomprehensible that an apparently intelligent farmer will one day curse the mice and the ground squirrels for their depredations upon him, and the next shoot every hawk, badger, and snake he comes upon.

The vegetable matter that muskrats take is of no consequence, and their burrows seldom interfere with irrigation. Appreciating the value of their pelts, some farseeing men of Utah will soon engage in "muskrat farming," which in the East is a profitable employment.

Nothing can be said in favor of the pocket gophers, whose burrows are the constant torment of a region that exists by reason of irrigation. The kangaroo rats (Perodipus) nibble the young sprouts of growing grain, and consequently are a nuisance.

Porcupines subsist on the bark of such trees as the aspen, jackpine, and hemlock, for which habit they deserve no censure; similarly the pikas or chief hares are far up in the mountains away from man.

Cottontails live on the tid bits of mountain vegetation, being valuable food for man; and jack rabbits while undoubtedly destructive should so far as practicable be killed for their fur and for food rather than poisoned.

Of the Felidae, mountain lions, ruthlessly killing deer, colts, calves and sheep, should everywhere be destroyed; and though the lynx and wild cats devour some prairie dogs and other rodents, they steal many lambs and are therefore harmful.

Wolves kill so many calves, and coyotes so many sheep that their extermination is a desideratum, though there is a noticeable increase of rabbits, rats and mice whenever coyotes are systematically hunted. In fact, the presence of coyotes is encouraged by the horticulturists of California. 
The pelts of the various species of foxes in Utah are so valuable that these animals must be protected if full advantage is to be taken of the state's resources.

So picturesque is the grizzly bear and so rapidly is it becoming extinct that a sentiment is growing in its favor. It eats berries, fruits, ground squirrels, gophers, pea vines, roots, cattle, deer, honey, pigs and carrion; but the author endorses a movement to enact a law permitting its destruction only' at certain seasons. It should be borne in mind that the mountains are for the whole people, not for certain classes; and no one doubts that the presence of wild animals adds greatly to the allurement of the woods. Black bears, really timid and harmless, likewise merit some consideration.

The value of the fur of raccoons counterbalances their destructiveness. On the other hand the habits of the badger, which constantly preys on ground squirrels, are so uniformly beneficial that this animal should be given the highest protection possible, with heavy penalties for its destruction.

Similarly the few hens' eggs taken by skunks are more than compensated by the many grasshoppers, crickets, insects, mice, rats, ground squirrels, frogs and rabbits which they destroy.

Weasels are harmful; but martens, minks and otters have such valuable furs that they should be given every encouragement.

Shrews and bats, being insect-eaters, merit the kindliest consideration, though the former are so small and the latter so retiring that seldom are either disturbed. One can only imagine what the mosquitoes would be if bats were to fly in the daytime and the many thoughtless owners of guns were permitted to wreak destruction upon them.

So little is known about many of our mammals that an unlimited field of research presents itself to the naturalist. When one thinks of such topics as: tracks, speed, environment, migrations, numbers, food, storage, means of communication, voice, sociability, senses, hibernation, amusements, mating, sanitation, training of the young, vice, crime, enemies, diseases, commensalism, age, and economic status, as applied to any one species, the lack of present knowledge becomes at once apparent and regrettable. It is only by the collation of the accurately made notes of many careful observers that the complete history of our mammals will ever be even approached. 


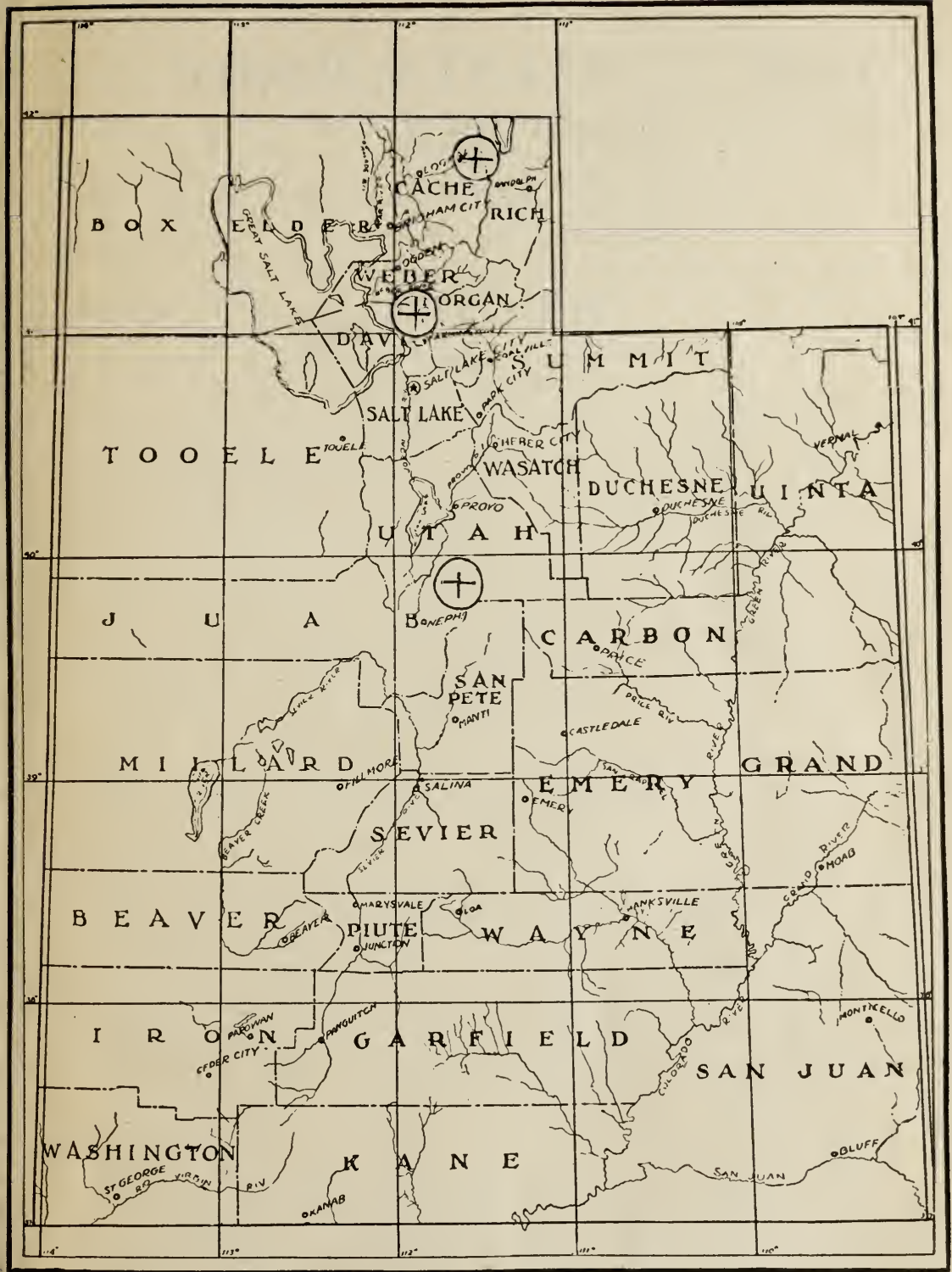

Map No. 2.-Records of the Moose (ALCES AMERICANUS Jardine) in Utah. From data assembled by Claude T. Barnes. 


\title{
Order UNGULATA: Hoofed Quadrupeds
}

\author{
Family CERVIDAE \\ Subfamily CERVINAE
}

\section{MOOSE}

\section{ALCES AMERICANUS (Jard.)}

Cervus alces Linn. Syst, Nat., 1, 1758, p. 66.

Alces americanus Jard., Nat. Libr., Mamm., 1835, p. 125.

Alces machlis Ogilby, Proc. Zool. Soc., 1836, p. 135.

Alces palmatus Gray, List. Mamm. Brit, Mus., 1843, p. 182.

Cervus lobatus Agass., Proc. Bost. Soc. Nat. Hist., 1846, p. 188.

Alces muswa Rich., Zool. of Herald, Mamm., 1852, p. 66.

Description-Muzzle very broad, produced, covered with hair; except a small, moist naked spot in front of the nostrils. Neck short and thick; hair thick and brittle; throat rather maned in both sexes; hind legs have tuft of hair rather above the middle of the metatarsus; the males have palmate horns. The nose cavity in the skull is very large, reaching behind to a line over the front of the grinders; the intermaxillaries are very long, but do not reach to the nasal. The nasals are very short. The moose is the largest of the American deer, quite equalling a horse in bulk. (Baird.) A fine bull moose in prime condition was black on forelegs, breast, shoulders, flanks, hams, shading into rusty brown on withers, back, neck, and head; palest on nose and lips and shaded into white on the belly; the insides of the ears also are whitish, the legs from the knee to the ground are a pale warm gray or Caribou color. The appearance of the animal at a distance is that of a black beast, with brown head and white stockings. The coat fades toward springtime. (Seton.)

Distribution-Many years ago John Burton of Kaysville, Utah, killed a moose on the mountain slope between Kaysville and Farmington, Davis County. According to Gerald Thorne of Logan, Utah, an occasional moose is seen in the Bear Lake region, Utah.

A man by the name of Barclay over a dozen years ago killed a moose at the head of Spanish Fork canyon. Herbert Cromar, who was then game commissioner, seized the head 
in Salt Lake City for prosecution; but it was found that Utah had no law on the killing of moose. The head was mounted by Mr. F. A. Wrathall of Salt Lake City, who informs me that it was a three-year-old male with very small horns and it had been shot with a shotgun. The head was finally sold through the Mehesy Company. As there is absolutely no doubt about the record, it marks probably the extreme southwestern limit for this species.

Habits-Unlike most animals the moose lives winter and summer in the same locality-sometimes in a swamp only three miles wide and ten miles long, or, again in a strip of mountainside. The winter yard may cover less than fifty acres; however, the moose is probably the widest ranger of the non-migratory ruminants.

The antlers, which are shed each year, are not fully palmated until the third set appears; but, thereafter, unlike those of the elk, they show little indicatior of the age of their possessor.

Both cows and bulls have the "bell," which is merely a long dewlap of skin, round, flat, or forked, hanging down eight or ten inches from the neck or the jaw. An experienced woodsman can readily detect the presence of moose by their "fumet" or dung bells, their sharp cow-like tracks, their trails deliberately taken across bogs, their wallows, their horn scrapings, and their nippings of twigs at great heights. Frequently they chisel the bark of trees at a height of from seven to ten feet, though they never completely girdle a tree.

Even after a bull moose has dropped his horns his forefeet are sufficiently dangerous bayonets to keep off a wolf or a bear. When the snow becomes three or four feet deep, the family makes regular trails from tree to tree; and if frightened away or compelled by hunger to seek other fields, they march in single file, parents in the lead. Jays flutter about their backs all winter, eating parasites from their backs and in turn warning their hosts of danger.

In the spring the bulls meander off alone to grow their horns and the cows retreat to have their calves, one each the first time, afterwards two or even three. Deer hide their fawns for weeks, but the moose calf follows its mother about when only three or four days old.

In the summer the families reassemble and become semi-aquatic, swimming constantly in the ponds. The bull's antlers begin to peel in July and by September they are ready for the annual battles.

The moose is the only deer that is strictly monogamous. So faithful is he in fact that he will not answer to a calling 
cow other than his mate. Only the eagle excells him in this respect, for death alone can sever its marriage tie.

The enemies of the moose are man, deer-flies, ticks, disease, deep snow, wolves, bears and mountain lions.

Dr. Hornaday informs me that it is strange that a forest-loving, brush-eating, water-frequenting animal like the moose ever could elect to settle down in Utah, but that the presence of a limited number in this state is fairly beyond question.

\section{WAPITI: AMERICAN ELK}

\section{CERVUS CANADENSIS (Erxleben)}

Cervus elephus canadensis Erxl., Syst. Regn. Anim., 1, 1777, p. 305 .

Cervus strongyloceros Schreb., Saugth., pl. cexLv11, 1792.

Cervus wapiti Barton, Am. Phil. Trans., 1869, p. 70.

Cervus canadensis Elliot, Syn. N. Am. Mamm., F. C. M. Pub. 11, 1901, p. 34, Zool. Ser.

Description-Body color of young bull, brownish gray, a little darker along the spine, and becoming dark chestnut or brown on head, neck and legs, and reddish brown or sienna color on breast and belly. The inside and lower back part of ears, a patch around the eye, a spot on each side of the lower lip, a spot under the jaw, are very pale brown or dull brownish white; the disk or rump patch is very large, of a pale, buffy white, and continued above the tail, which is of the same color; bordering this patch in front, on each ham, is a brownish black stripe that nearly fades out towards the spine where it joins its fellow. (Seton.)

At the State Capitol building, Salt Lake City, is a fine mounted male specimen, with pelage almost white. The males frequently thus appear in spring, the summer colors being richer and darker. Seton says that the word "wapiti" is supposed to come from the Algonkin roots wab, white, and atik, deer. The females in the summer resemble the males in color; and the fawns are yellowish spotted with white.

Dr. William T. Hornaday measured a fine bull in the New York Zoological Park, finding its height at the shoulders $561 / 2$ inches, length of head, body and tail, $863 / 4$ inches. Its live weight was 706 pounds. 


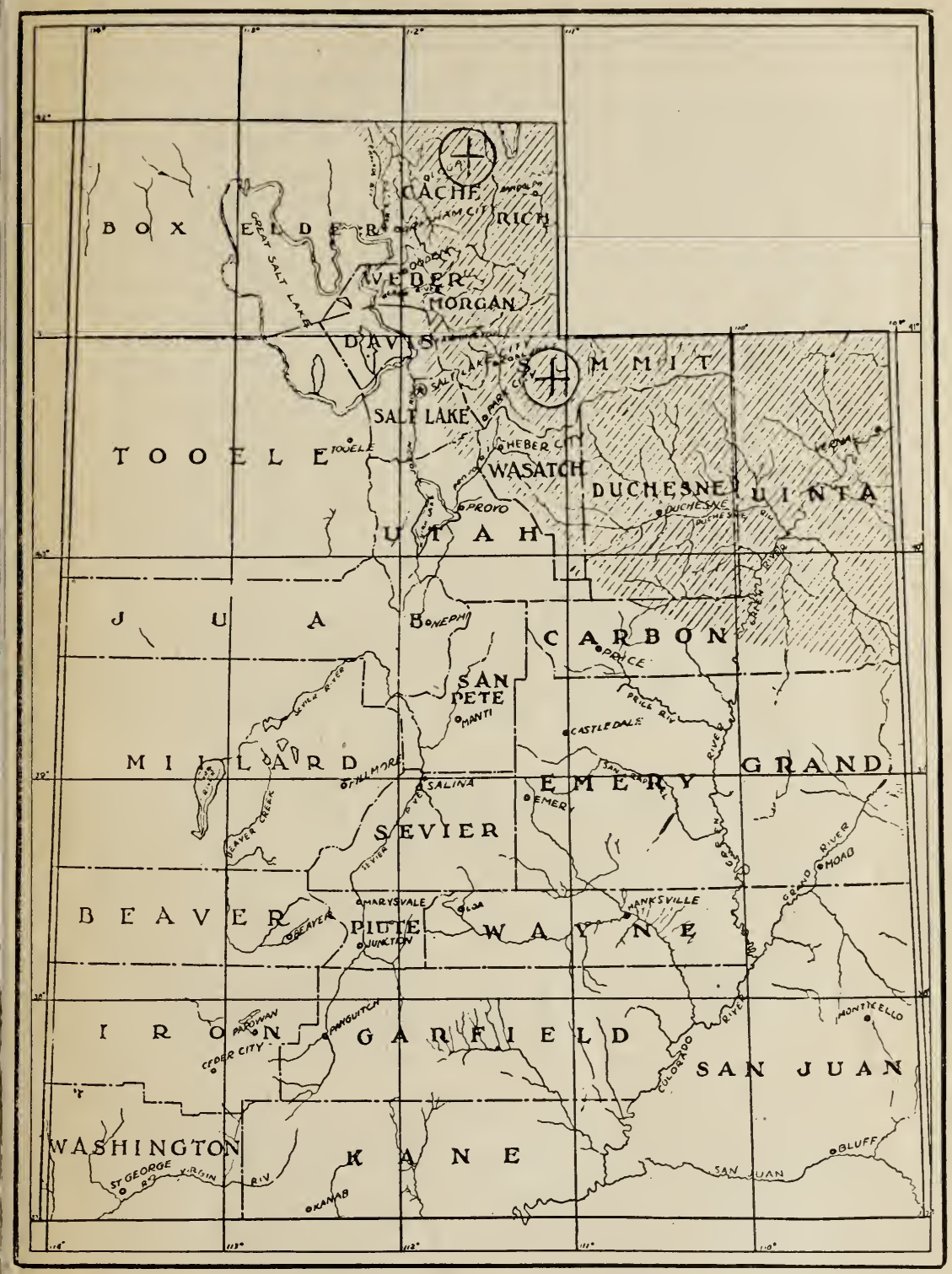

Map No. 3.-Range of Wapiti or Elk (CERVUS CANADENSIS Erxl). (Shaded area) approximate distribution in 1500; (crossed circles) actual present records of wild animals. Founded on E. T. Seton's map and records by Claude T. Barnes. 
Distribution-Formerly the elk was spread over the greater part of the United States, though early records for Utah are unavailable. The only elk indigenous to Utah are seven head known to be on the Uinta division of the Wasatch national forest. Two large bulls have ranged near Kamas for some time.

Elk have been imported from Wyoming with great success. B. E. Mattsson of Ephraim informs me that there are fifty elk on the Manti forest. At first they were placed in Cottonwood canyon near Orangeville; but some of them have drifted to the Fishlake district. Theodore Seeholser of Logan, Utah, says that there are six wild elk far back in the mountains above Logan, in Blacksmith Fork canyon; it is possible that they are indigenous. C. A. Mattsson of Salina says that the elk imported from Wyoming to the Fishlake district have now increased to 58 head. A. W. Jensen of Provo estimates that there are 145 elk in the Uinta National forest. L. F. Kneipp, District Forester, Ogden, Utah, says that during 1917 the transplanted elk in Utah increased from a total of 299 to 327.

Professor Marcus E. Jones reports to me that in 1888 the elk were so numerous on LaMott's Peak in Uinta that they tramped down the grass in the subalpine basin. The next year he heard bull elk fighting near Hayden's Fork of the Bear river.

Habits-When at the beginning of the last century, millions of buffaloes and elk reigned supreme over the plains and mountainous regions of North America, few hunters could foresee the extermination of the vast herds of wild game about them, in the lifetime of their children. Today, however, there are few if any wild buffaloes, and the homesteader is gradually crowding the few remaining bands of elk out of their winter feeding grounds. A tragedy of nature is being enacted with the curtain almost ready to fall on the last scene.

The haven of the elks, today, is Yellowstone Park in summer and Jackson's Hole, Wyoming, in winter. In the spring, the cows graze along the rich, low valleys, while the bulls seek the higher plateaus. The calves, usually one though sometimes two or even three to a cow, are born in May; and for the first few days the mother hides her little ones in bushes. There each lies as if a log, its unwinking bright eyes taking in every movement of the intruder but its tiny body remaining perfectly still. Its big white spots resemble patches of sunlight midst dark shade and thus are a protection, not a disclosure. 
After a few days the calf wanders with its mother, who, however, still hides it in times of danger; but by October the youngster is able to forage for itself.

Elk wallows are accredited to the bulls, who enjoy the mud as much as a hog; but a dozen or more, cows and bulls, have been seen wallowing together, apparently for mere amusement. At times elk have been seen in a sort of circle dance, twenty or more of them running around in a ring for a half hour or more with no object, perhaps, except the fun of the game.

The crowning glory of the stag is his antlers, which are grown afresh each summer. Each March they break off at the base an inch or more above the skull. Within three days afterward the raw spots have become velvety bulbs of skin gorged with blood; and in two weeks are soft antlers several inches high, hot with blood vessels. In four months the antlers are once more complete, and the velvet begins to peel off.

It is said that any injury, any sickness, even a cold, affects the size of the antlers; in fact the horns each year reflect the vicissitudes of their owner while growing them. Each season the horns increase in size until the sixth, when they decline year after year until the end. The fallen horns are eaten by mice, gophers, rats and porcupines.

With antlers perfect and bodies trim the bulls descend from the mountains in the autumn and as soon as the cows are sighted the world-famous bugling begins. Each big bull takes his cow, seeks an eminence and trumpets his defiance to the world. The tones resemble somewhat the bray of a jackass.

Young bulls do not bugle but whistle. Hence if in answer to a young bull's note, there comes through the glen the clear bugle call of an old stag, the young bull immediately pushes his cows along with his horns until he has them hidden from the enemy.

\section{WESTERN WHITE-TAILED DEER}

\section{ODOCOILEUS VIRGINIANUS MACROURUS (Rafinesque)}

Cervus macrourus Rafin., Amer. Month. Mag., 1817, p. 436.

Cervus leucurus Dougl., Zool. Journ., iv, 1829, p. 330.

Odocoileus americanus macrourus Elliot, Syn. N. Am. Mamm. F. C. M. Pub., 11, 1901, p. 39.

Description-The prevailing color of this species in the fall of the year is a yellowish gray, clouded and waved with black caused by the dusky tips of the hairs. This color is 


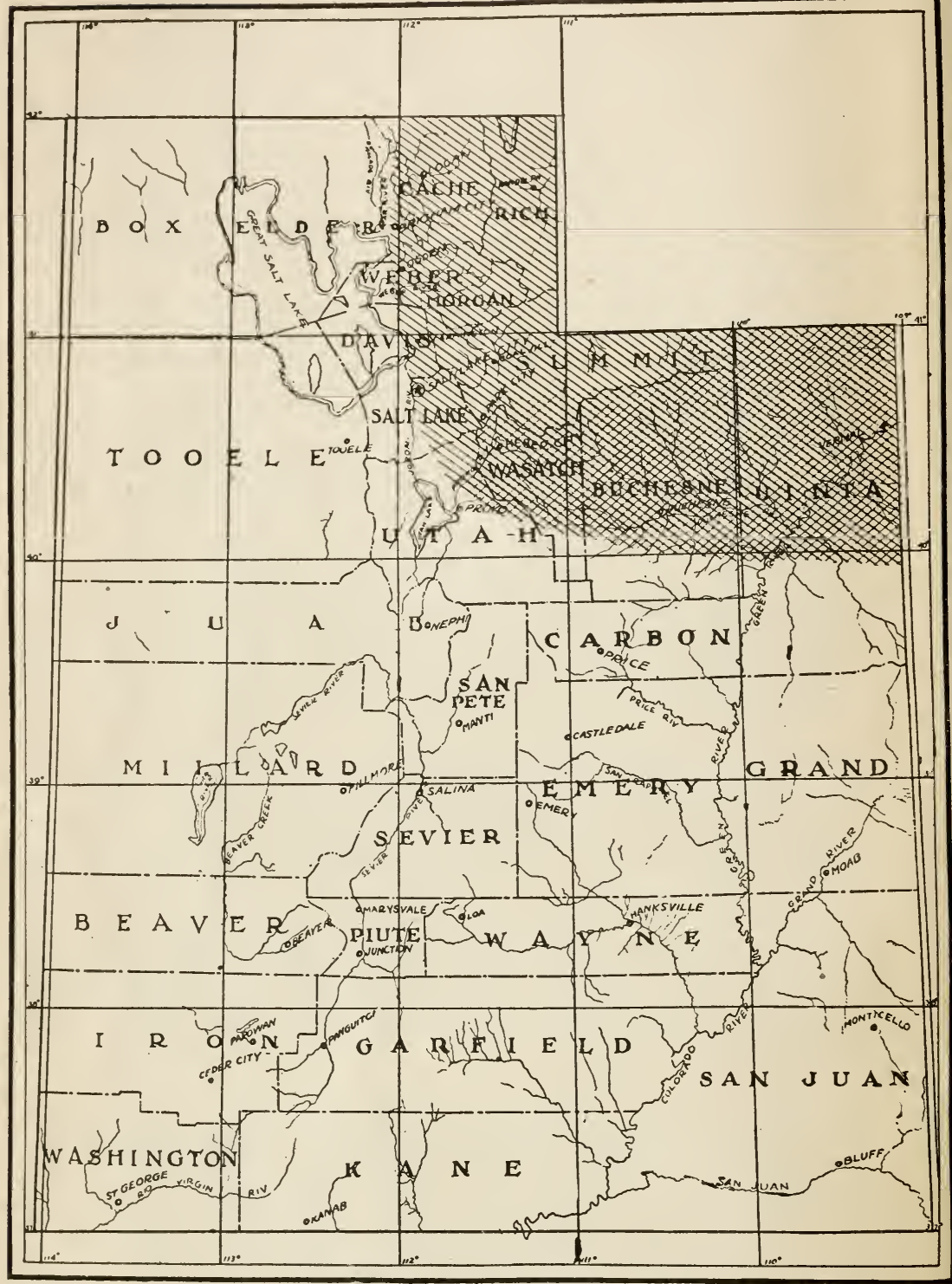

Map No. 4.-Distribution of Western white-tailed deer (ODOCOILEUS VIRGINIANUS MACROURUS Rafinesque) in Utah. (Whole area) distribution in 1850. (Cross line area) present range. Based on E. T. Seton's map and records by Claude $T$. Barnes. 
purest and grayest on the neck (nearly the same all round) and head, the long hairs on the top of the head only being more fulvous. The chin and throat are dull white, the former without any band, but merely a dusky spot on the side; there is also a suffusion of dusky on the sides and on the top of the upper jaw just behind the muzzle, but no continuous ring. The ears are uniformly brownish gray, lined and pointed somewhat with dusky, the concavity and the basal portion behind being white. The under part of the neck, from the white patch beneath the head to between the forelegs is of the same brownish gray, with a slight sooty tinge posteriorly; the rest of the under parts to the tail are opaque white. The under part of the tail and the region around the anus are also white, but apparently less conspicuously so than in C. virginianus. The upper surface of the tail is of a uniform reddish brown, brighter than elsewhere on the body. The legs are of a nearly uniform pale brownish yellow, rather lighter internally. (Baird.) In the summer pelage the upper parts and the outside of the limbs are reddish brown. The fawns are spotted. Warren gives the total length as 90 inches with tail vertebrae, 12 inches.

Distribution-The former range of this deer extended from Kansas, Nebraska and the Dakotas westward into the Rocky mountains, and from Alberta to northern Mexico. Seton says that its range has recently been extended into Utah, where irrigation favors it. William M. Anderson of Vernal, Utah, says that there are probably 175 to 200 head in that part of the state, most of them being found along the Green River canyon in places that are entirely shut off from game hunters on account of the topography of the country.

Mr. F. A. Wrathall informs me that while he has never mounted a white-tailed deer head that he knew to have come from Utah, he has nevertheless, been told by many old settlers that in the very earliest pioneer days this species was quite common in the swamp that was formed by City Creek on the site of the present Bonneville Park within the city limits of Salt Lake City. The same was true of a swamp at the mouth of Mill Creek Canyon, Salt Lake county.

Habits-In summer white- tails are usually solitary or wander through the forest in parties of two or three. In winter, where the snowfall is heavy, they gather in parties, sometimes of considerable size, in dense deciduous growth, where food is plentiful. There they remain throughout the season, forming a "yard" by keeping a network of 


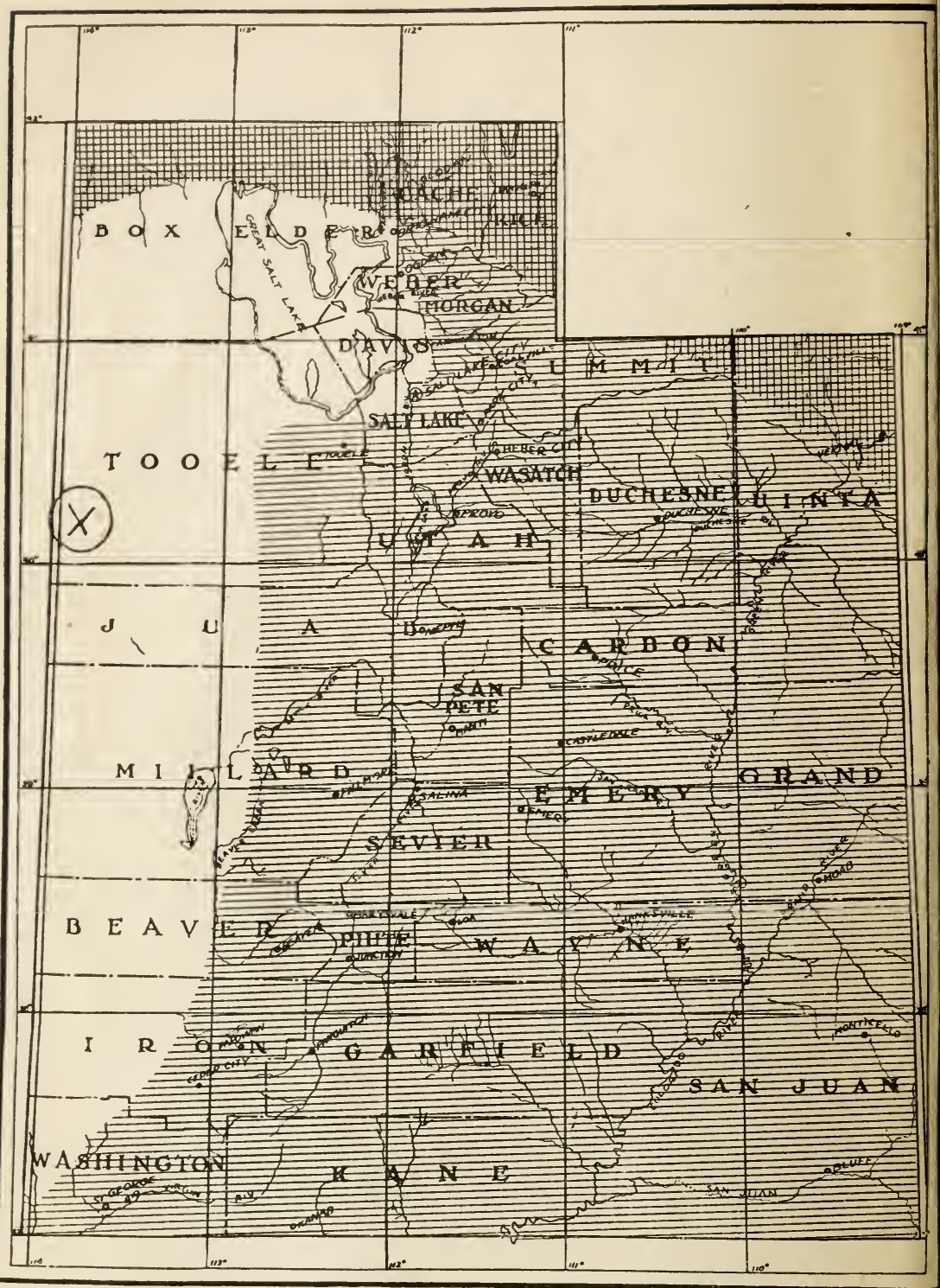

Map No. 5.-Range of Mule deer in Utah: (Crossed line area) range of ODOCOILEUS HEMIONUS Raf.; (straight line area) range of ODOCOILEUS HEMIONUS CANUS Merriam. Based on E. T. Seton's map and records by Claude T. Barnes. 
hard beaten paths open through the snow in order to reach the browse afforded by the bushes and trees. (Nelson.)

Being protected just now by the unexcelled game laws of Utah, these animals have become remarkably tame in some localities. They prefer the dense brush, while the mule deer seeks the open tracts of the hillsides.

\section{MULE DEER}

\section{ODONTOCOELUS HEMIONUS (Rafinesque)}

Cervus hemionus Rafin., Amer. Month. Mag., 1, 1817, p. 436. Cervus auritus Ward., Desc. Etats. Unis. v, 1820, p. 540.

Cervus macrotis Say, Narr. Long's Exped. Rocky Mts., ii, 1823, p. 88.

Odocoileus hemionus Elliot, Syn. N. Am. Mamm., F. C. M. Pub., 11, 1901, p. 42, Zool. Ser.

Odontocoelus hemionus Elliot, Mamm. Mid. Amer. and W. Indies, F. C. M. Pub., iv, p. 76, 1904.

Description-Winter or blue coat.-In general a warm orownish, gray, thickly peppered with black tips and rings on the individual hairs. The inside of legs, the belly, and patch on buttocks are white. The face and throat are dull white with a large black patch on the forehead and a black bar around the chin. The tail is white, except the bunch on the tip, which is black all around. The legs below the knees and hocks are clear sienna brown. Sometimes the breast is brownish black. This represents the blue coat; a month earlier it would have been much darker and slatier. Summer or red coat-The red coat appears in May and is worn until late August. It is rusty yellow rather than red; the head, tail, and legs change little with the season. The female is similar to the male, but duller. The fawn is dull yellowish, thickly spotted vith white. (Seton.) The tail is cylindrical, a little longer than the ears, very slender, naked beneath, except at the end, which is a black tuft. Horns doubly dichotomous, the forks nearly equal. (Baird.) Seton gives the weight of a typical buck as $2153 / 4$ pounds. Hornaday, says that this deer is easily recognized by its very large ears, the two Y's on each antler, a short, white tail with a small tip of black, and a white patch around the base of the tail. 


\section{(2) CHIHUAHUA MULE DEER}

\section{ODOCOILEUS HEMIONUS CANUS (Merriam)}

Odocoileus hemionus canus Merriam, Proc. Wash. Acad. Sci., iii, 1901 , p. 560 .

\section{Description-Smaller and paler than typical hemionus.}

Distribution-The typical hemionus is confined in Utah to the extreme northern part of the state, its race, canus, occupying probably the major part of the state; but as material is not at hand to determine the exact limits of the two, they are treated here together.

L. F. Kneipp informs me that mule deer are increasing in all of the Utah national forests except the Dixie, Powell and LaSal. George H. Barney of Escalante says that they are quite numerous in the Escalante forest, as well as south and east to the Colorado river. He estimates 2,000 as the number in the entire forest. Brigham Spencer of Moab says they are quite numerous in Garfield, Wayne, San Juan, Grand and Emery counties. B. E. Mattsson of Ephraini says that it is estimated that there are 550 rnule deer and 50 elk on the Manti forest. He adds: "The industrial developments of the country have materially affected the egress and ingress of wild game; particularly is this true on the west and north sides, where there is but little winter range, and I do not believe any big game attempt to winter on the forest on the west and north sides. At the time this country was settled the forest ranges were teeming with wild life. There were no game laws in effect and as a consequence the wild game was greatly diminished. Winter range, which a few years past produced :mple feed for wild game, is now fully consumed by domestic :nimals which have precluded the wild game."

C. A. Mattsson of Salina estimates that there are 1400 mule deer in the Fishlake national forest. "The mule deer," he says, "is found in all the juniper-pinon and low oak brush type of country in this vicinity during the winter seasons, and in the higher ranges during the summer periods." Clinto Milne of St. George says: "The mule deer on the forest reserve in this part are estimated at 750 head. This does not include all of the county (Washington) as deer are found in other mountains which the forest reserve does not cover. The deer in this part are just about holding their own as mountain lions are numerous and kill many." J. W. Humphrey of Panguitch says that deer are numerous on both divisions of the Sevier forest; also in the lower country 
used as winter range for cattle and sheep. E. C. Shepard of Logan estimates that there are 250 mule deer in the Cache national forest. William M. Anderson of Vernal informs me: "Mule deer are fairly plentiful; they are pretty well distributed over the entire Uinta mountain range. I believe that a conservative estimate of the number within and adjacent to the Ashley national forest would be 3,500." I have seen mule deer in the mountains west of Tooele City; and several have been taken in recent years from the canyons, immediately above Salt Lake City.

Mr. F. A. Wrathall of Salt Lake City, taxidermist and a very reliable observer, informs me that he has mounted mule deer heads from every county in the state.

Professor Marcus E. Jones informs me that he saw the horns of the mule deer at Ibapah, in the western end of Tooele county.

Mr. S. B. Locke and H. S. Rutledge inform me that these deer are fairly common over the entire LaSal National forest, particularly along Upper Pack creek, and on the desert between Grand and Green rivers. The Indians hunt them persistently in the Blue mountains.

Habits-The antlers of the mule deer are dichotomous, that is, they are an arrangement of even forks instead of a main branch with snags.

Quieter than other cervidae the mule deer nevertheless has varied sounds to express different feelings; when curious, it "snorts" or "blows"; when alarmed it "whistles" and the doe murmers softly to her fawn, which "bleats" vociferously if lost. Both bucks and does bleat like sheep when in extreme danger; and the buck gives a bark or challenge in the rutting season. Both stamp the forefeet in expressing defiance or alarm.

Though non-migratory in the strict sense of the word, the mule deer will nevertheless ramble for a hundred miles or more in search of meadows yet free from snow. Thus each year hundreds desert the high Colorado ridges for the arid or semi-arid brakes of Uinta county, Utah, a hundred or more miles away.

If undisturbed a group of two or three mule deer will spend the entire summer season within a hundred acres of hillside, and, especially so, if cover is good and pea vines abound. As the snow melts in spring, the winter groups scatter; and at this time the repulsion of feeling between the sexes is so strong that does ramble off with does and bucks with bucks, the latter with such equanimity that they meander at times two and two all summer. 
Each doe soon seeks a lonely retreat, where in late May, one, two or rarely three fawns are born. These she hides in a thicket, suckling them night and morning. Twice a day she seeks a pool to drink and at various hours eats grass, twigs, in fact anything of a vegetable origin. Should danger threaten the little ones, a cry from her causes them to drop as flat as a quail; and even when six or eight weeks old, after they have begun to follow her, they hide themselves so cleverly that close search is required to find them. Should a hawk appear the mother evinces solicitude by raising the hair of her neck and watching the ominous movements of the intruder; a coyote is dealt with in a more summary manner and usually chased ingloriously out of bounds. The buck probably takes no interest in the fawns.

In November the ardor of the rutting season causes many a push fight; but soon thereafter, when snow flies, bands of all sexes gather amicably together under the leadership of a grandmother doe. Food then consists of anything green, whether procured by pawing the snow or by standing on the hind legs.

Deep snow is, next to guns, the mule deer's direst enemy. Food is hopelessly buried and rapid travel is prevented. Then it is that the mountain lion licks his lips with feline glee, for he has but to strike to win. To his discredit, however, he is not content with the one deer a week that his stomach could accommodate, but must kill four or five victims a day until all the band is prostrate on the snow. Then he lingers no longer, but seeks other fields.

Wolves, lynxes, coyotes, and eagles probably molest only the fawns. Bluejays, however, hover about the mule deer, at once companions and watchmen.

A mule deer can swim if compelled, but it dislikes the water. Old and young are frequently seen gambolling together like lambs, the only amusement they are known to indulge in. 


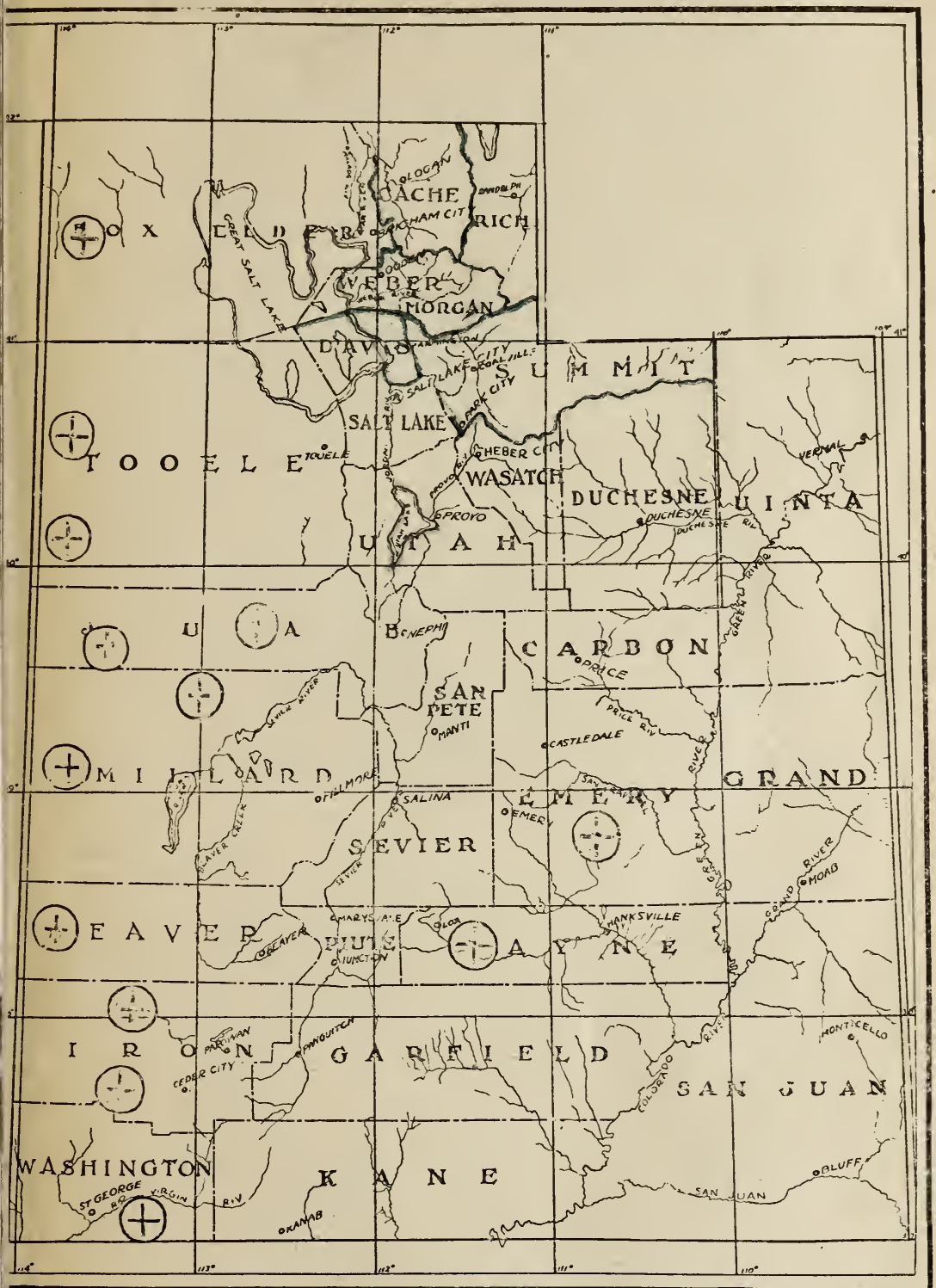

ap No. 6.-Range of Pronghorned Antelope (ANTILOCAPRA AMERICANA Ord) in Utah. Based on records by Claude T. Barnes. 


\section{Family ANTILOCAPRIDAE. Prong-horn Antelopes}

\section{PRONG-HORN ANTELOPE}

\section{ANTILOCAPRA AMERICANA (Ord)}

Antilope americana Ord, Guth. Geog., ed Am. ed., ii, 1815, p. 292.

Antilocapra americana Elliot, Syn. N. Am. Mamm., F. C. M. Pub. ii, 1902, p. 43.

Description-Color above yellowish brown, or pale dun color; a narrow transverse band between the eyes, the top and sides of the muzzle, and a patch beneath the ear, (wanting in the female) liver brown; edges of upper lip, chin and sides of face, spot behind the ear, a narrow crescent on the upper part of the throat, a triangular patch below this, the entire under parts and a square patch on the rump, white. Horns, hoofs, and naked parts of the nose, black. Horns rudimentary or wanting in the female. Eye, large and full. Tail, short, almost rudimentary, measuring only a few inches. The young of the species in general have the same markings as the adults; the brown of a different shade however. (Baird.) The largest buck antelope in the Zoological Park, New York, stands 371/2 inches at the shoulder; has a head and body length of $473 / 4$ inches; tail $31 / 2$ inches. (Hornaday.) Seton gives the weight of a four months-old buck as 60 pounds and of a large one as 125 pounds.

Distribution-Originally this animal was found all over Utah; but it is now fast nearing extinction. Brigham Spencer of Moab says that in 1895 he saw bands of twenty or more on the San Rafael swell, Emery county. He has also seen them in Rabbit valley, Wayne county. Clinton Milne of St. George says that a few antelopes are still on the desert in the vicinity of Antelope Spring, near Newcastle, Utah, and there are a few around Rock Canyon, Arizona, about twenty miles southeast of St. George. J. W. Humphrey of Panguitch reports that one solitary antelope was recently seen in Emery valley. William M. Mace of St. George says that a few are found in the Escalante desert north of Enterprise, Utah. C. A. Mattsson of Salina informs me that the bones of antelopes are sometimes found in the mountains of that vicinity, but no live animals have recently been seen.

Mr. F. A. Wrathall has mounted heads taken in the desert near Cedar City, and fifteen years ago he mounted a head that was taken in Utah, near Wendover. 
Professor Marcus E. Jones says that antelopes are still seen occasionally on all the plains of western Utah from Lund to Antelope valley, Nevada. In 1891 he saw a herd of twenty at Gold Hill, Nevada, just over the Utah line, and believes that their range extended undoubtedly into this state.

F. W. Parker says that there was a herd of three hundred antelopes on Judd Creek, thirty miles west of Tintic, Juab County, in 1911, and that sheepherders report that they are still there. He saw them every day during one summer. They would come in early each morning to visit a well known salt lick; and when chased they invariably ran southward into a district of such loose sand that a horse could not run in it at all. This protective part of the desert may for a long time prevent the extermination of this particular band.

Habits-Swift as an arrow and as graceful as Hyperion, the antelope is truly the Ladas of the woods, the fleetest animal of the wilds. Elegance, too, is its natural attribute, for its delicate shape is second only to its wondrously beauteous eyes.

A level stretch of open country two miles across seems sufficient for an antelope's individual range; and if the winters are mild and enemies scarce this patch is apt to be made the permanent residence. In eastern Utah, when the snow flies, antelopes congregate in the sheltered valleys of the mountains.

The horns of the antelope are shed each year, a fact discovered by Rufus B. Sage in 1841. The buttocks of each antelope are white; and the hair can be raised at will. This discograph, when raised, shines in the sun like a tin pan. From glands in the center of each hair disc is issued in times of danger a musk, which so scents the air that other antelopes can smell it actually for miles, and thus avoid the wolf or whatever excited it.

The voice of the antelope to her kid is a querulous, grunting bleat, though adults of both sexes give shrill whistles or snorts when alarmed and bark when very curious. The kid utters a bleat or squeak.

The seraphic eyes of the antelope are larger and probably milder than those of any other animal of the same size. The poor creatures actually shed tears when in terror or despair.

Being creatures of the dry plains, antelopes live on grass, cactus, and sage, but they never browse on twigs and 
leaves, nor eat acorns. In some parts of Utah they probably go entirely without water.

The young are born in May, and the little fellows, usually two, follow the mother when two weeks old, but lie perfectly still at a signal from her. Flies cannot make them even wink at such a time.

In September the bands assemble and soon thereafter the bucks begin their annual fighting.

Family BOVIDAE. Oxen, Sheep, Goats Subfamily RUPICAPRINAE

\section{MOUNTAIN SHEEP}

\section{OVIS CERVINA (Desmarest)}

Ovis cervina Desm., Nouv. Dict. Hist. Nat., 1804, p. 5 .

Ovis canadenis Shaw, Nat. Misc., 1804 ? pl. 610.

Ovis ammon Mitch., Med. Rep., 1807, p. 35.

Ovis pygargus H. Smith, Griff, Anim. Kingd., v, 1827, p. 318.

Ovis californianus Dougl., Zool. Journ., 1828, p. 332.

Description-Much larger than the domestic sheep. Horns, in the male very large, curving round, but rarely completing a full circle, and with but little spiral twist, compared with other species. The tips of the horns not more than twenty inches apart. General color grayish brown, paler about the head; a light patch under the lower jaw. Legs like the body, with a narrow line of white on their posterior edges. Buttocks, for some inches anterior to the tail, and belly, white. Tail like the back. Female with smaller horns more like those of the goat. Hoofs black; horns yellowish brown. (Baird.) All desert specimens are much paler in color than those inhabiting well-watered, heavily forested regions. (Hornaday.)

Distribution-The general range of this species is from the high mountain ranges of the Colorado river north into British Columbia. Brigham Spencer of Moab reports that he has taken them on Escalante Creek, Garfield county, Utah, and on the Grand river in Grand county. Carl P. Arentson says there are 106 mountain sheep on the whole Uinta mountain range. Clinton Milne of St. George informs me that there are a few mountain sheep in the pink ledges of Little Zion canyon near Springdale, Washington county; 


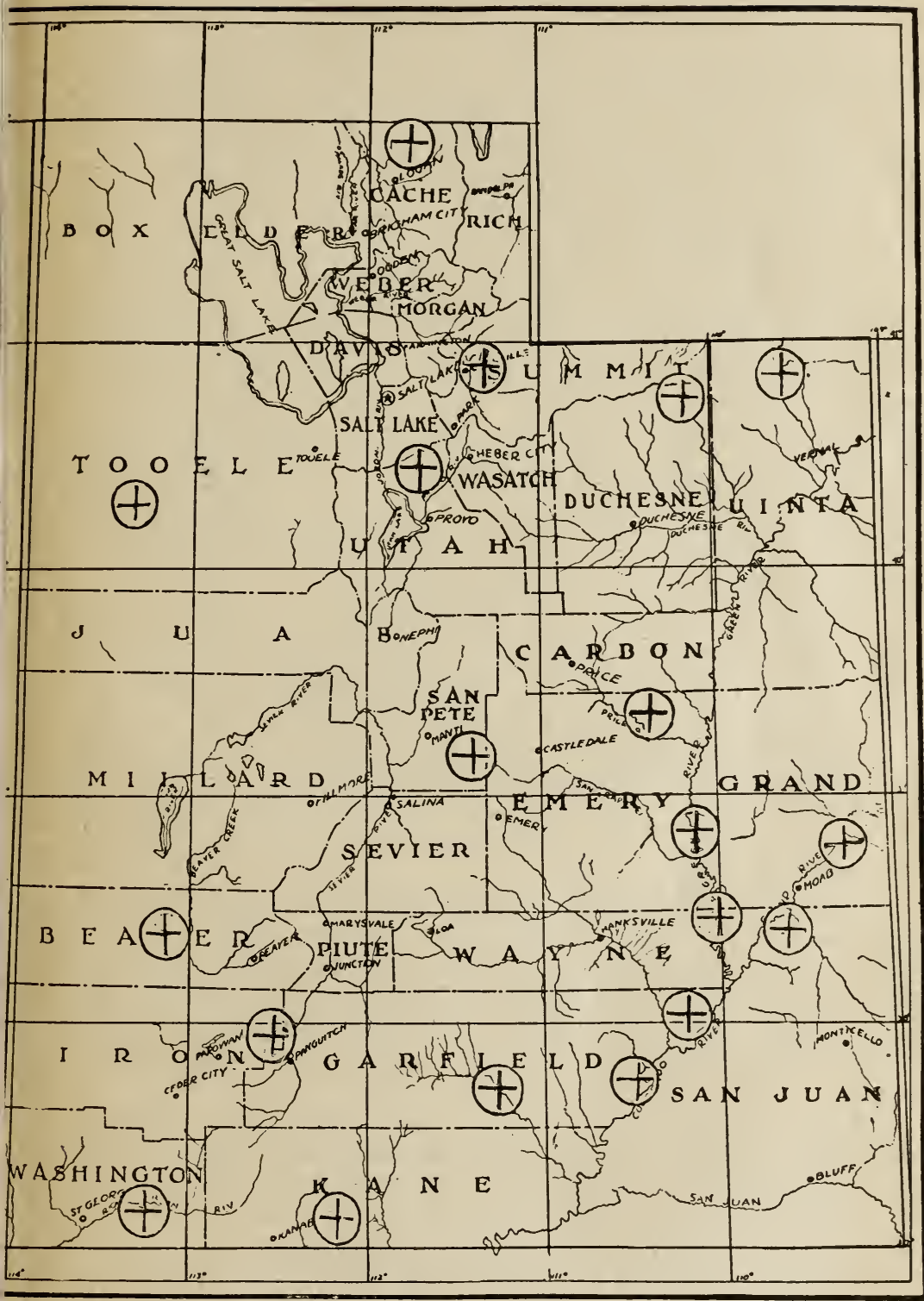

(p No. 7.-Range of Mountain Sheep (OVIS CERVINA Des.) in Utah. Based on records by Claude T. Barnes. 
he estimates about twenty-five head. C. A. Mattsson of Salina, says that the horns of the mountain sheep are sometimes found on the mountains there but that none of the live animals have been recently seen. According to J. W. Humphrey of Panguitch big horns were formerly numerous in the mountain ranges west and north of Panguitch; but they have now been nearly exterminated.

Theodore Seeholser of Logan took some mountain sheep west of Tony grove; and saw several in Cottam canyon in 1905 and in 1914. William M. Anderson of Vernal writes me as follows: "There are probably four hundred head of mountain sheep in the Ashley forest. Generally speaking the game situation in this section is below the average, I believe, for the middle west. On account of the Utah and White River Indians being located in this part of the state, most all of the game animals have been intensively hunted for many years and not given much of a chance to recuperate. Besides on account of our being quite a distance away from the centers of population the enforcement of our protective laws has been rather limited."

Mr. F. A. Wrathall reports that he once saw eight head of mountain sheep on the north slope of the Uinta mountains at the head of Black's Fork, and that a very fine specimen was found last year by a Mr. Brewer as the animal was floating dead down the Virgin river. Twenty years ago Robert Walker found mountain sheep at the head of Hughes' canyon near Twin Peaks, Salt Lake county, and they have recently been reported from Mount Timpanogas, near Provo, Utah.

Professor Marcus E. Jones informs me that he has seen this species near Kanab, along the Grand River, near Castle Dale and on the Frisco mountains in Beaver county. Professor Orson Howard one time secured a hybrid pelt from near Kanab, where this species crossed with the domestic sheep. The pelt was for some years at the University of Utah.

F. W. Parker reports that there are a few mountain sheep left on Granite mountain, Tooele county; and George Perkins of Pleasant Green has a bighorn skull overgrown by a tree, which was taken from the same vicinity.

S. B. Locke says there are a few along the canyons of the Green, Grand and Colorado rivers. Some appear frequently along the Grand river near Moab, occupying the same vicinity winter and summer.

Dr. Hornaday informs me that he had reports of the existence of mountain sheep at Little Pinto in 1899, his 
informant being G. C. Goddard, and in 1896 D. Arrowsmith reported a band at Willard in the Wasatch mountains.

Habits-It is said that the task of Sisyphus in the world of shades is to roll a huge stone to the top of a hill and fix it there despite its irresistible tendency to bound down again each time the feat is seemingly accomplished. It is just so in hunting the mountain sheep, whose head is usually the most valued prize among the trophies of the American hunter's den: mountains of irksome and dangerous acclivity must be scaled; narrow, crumbling ledges ribboning cliffs of dizzy heights must be traversed; and all of the comforts of camp must be left with the horses in the timber line far below.

The females of all wild sheep wear horns, though smaller than those of the bucks. The flesh of all varieties of mountain sheep, is so delicious as to afford a real stimulus to the hunter.

During the winter the bighorns, young and old, mingle in bands in their favorite localities. Bleak winds and driving snow do not worry them for their warm coats are so closely matted that only the indifferent protection of a cliff is sought during the worst storm. They live so high, indeed, that every blast serves only to denude everything of snow; but should a mantle of whiteness remain, the resourceful sheep paws in precisely the right place until the delicate green appears. After exceedingly heavy snows this species will at times go down to the timber.

When a blizzard is raging over every ridge, the sheep huddle side by side, the little fellows crouching low between the adults. Old males at such times become restless and prowl about, nibbling indifferently. Sometimes, however, the entire band is snowed under in a cave; but even then the stout old males work a way out with their horns.

As the warm rays of the spring sun fill every living thing with new vigor, the rams wander away alone into the tiny meadow-oases, midst the rugged cliffs of the higher mountains. Here at the very foot of eternal snow the bighorn lives a peaceful life. By the middle of July the old coat has been shed for a new and by the last of September the lonely ram is as fat as butter. As the chill blasts come he once more joins the family herd on the hillside below, taking but cursory interest in the stout, frolicsome lambs. 


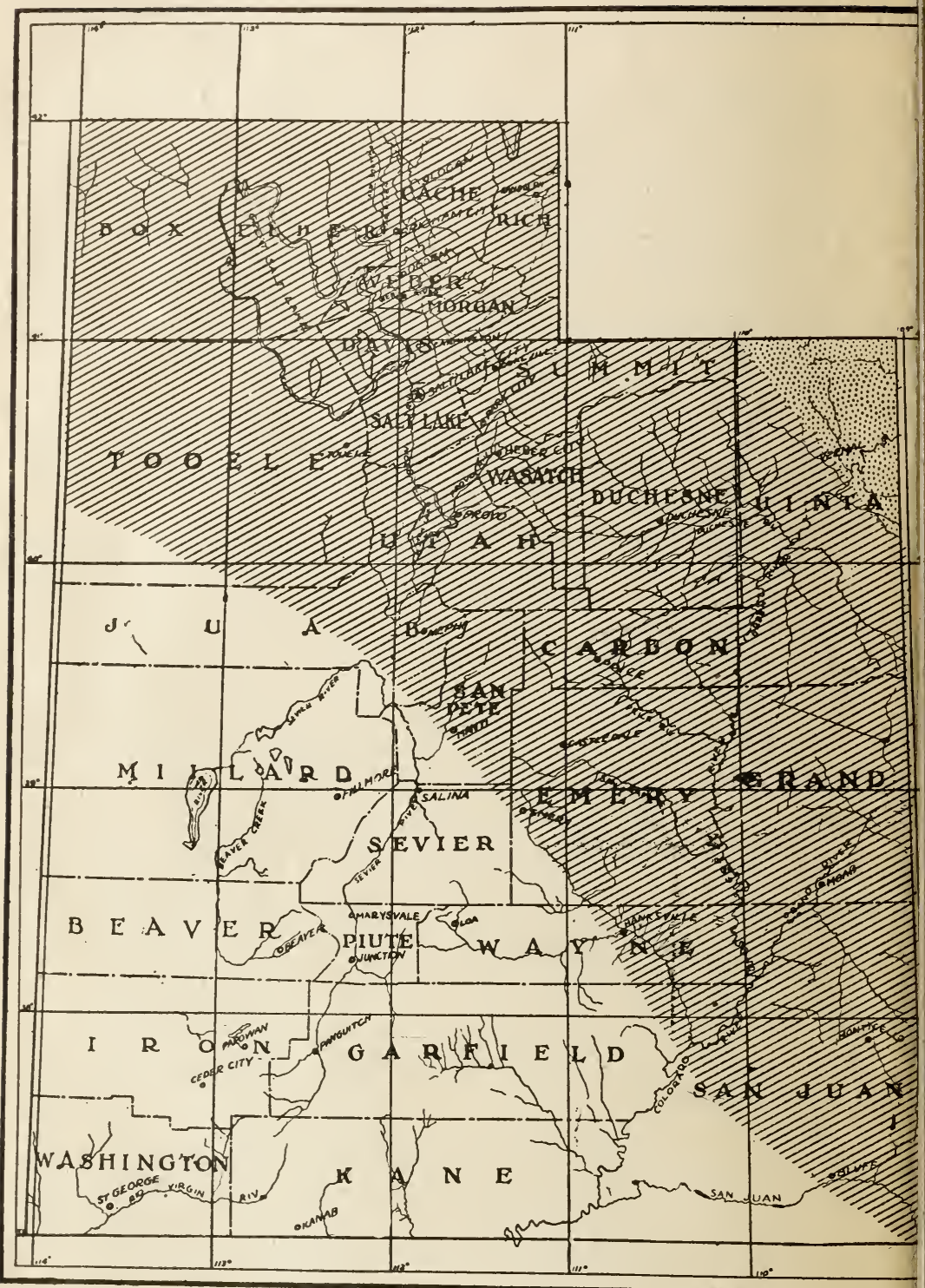

Map No. 8.-(Whole shaded area) range of Buffalo (BISON BISON Lin in Utah in 1500; (dotted area) range in 1850. Compiled from E. Seton, Dr. J. A. Allen and Dr. Wm. T. Hornaday. 


\section{BISON: AMERICAN BUFFALO}

\section{BISON BISON (Linnaeus)}

Bison americanus, Elliot, Syn. N. Am. Mamm., F. C. M. Pub., 11, 1901 , p. 49.

Bes bison, Linn., Syst. Nat., 1, 1758, p. 72.

Bison bison, Elliot, Syn. N. Am. Mamm., F. C. M. Pub., 11, 1901, Suppl., p. 486.

Description-The bull has the head, tail, legs, lower parts of neck, and shoulders, dark brown, shaded into lighter brown on the upper parts of the body, palest on the shoulders and hump; towards spring, all the upper parts of the body bleach into a dull brownish yellow, beside which the head looks black. The cow is similar but darker in the body color. At birth the calf is dull reddish-yellow, paler on the legs and under parts; at six months it is more like the mother; at two years it is everywhere a deep glossy, blackish brown; after this it again grows paler with age. Average weight of bull 1800 pounds. (Seton.)

Distribution-At about the year 1500 the range of the buffalo included all of Utah except the southwestern third, and in 1850 a few probably survived in the extreme northeastern part of the state close to the Colorado-Wyoming line. A small herd has for years been kept on Antelope Island in the Great Salt Lake, where they exist in almost a wild state. A few wild survivors of the original hordes of buffaloes are said still to exist in Canada, and of course there are some yet in Yellowstone Park. It is estimated that there are now about 4,000 buffaloes alive, about equally divided between the United States and Canada. This includes both wild and captives.

Professor Marcus E. Jones informs me that in 1898 he picked up a buffalo skull near Saltair, Salt Lake county; and that the Ute Indians say that the buffalo ranged throughout all northern Utah until about twenty years before the white men came to this state (1820) when they were all killed off by a snow storm of over four feet depth. Dr. Hornaday tells me that this was the greatest slaughter of bison by natural causes ever known.

As suitable localities are available Utah should by all means have a state herd of bison.

Habits-The sad story of the buffalo-how it decreased from about fifty million individuals to less than two thousand in a few years-is known to everyone. It was 
the principal source of food for the early Mormon pioneers when coming to Utah, though not after they reached this state.

Although the buffalo has but a single calf a year, ordinarily they do very well in large preserves.

The buffalo was the principal game animal of the Indians, who made their clothing and tepees of the skins, ate the flesh at all seasons and even kept tribal histories by writing or drawing pictures on the smooth surfaces of the tanned skins. 


\section{Order RODENTIA: Rodents}

Family SCIURIDAE. Squirrels, Marmots, etc. Subfamily SCIURINAE

\section{WIND RIVER MOUNTAINS CHICKAREE}

\section{SCIURUS HUDSONIUS VENTORUM (Allen)}

Sciurus hudsonius ventorum Allen, Bull. Am. Mus. Nat. Hist. N. Y., 1898, p. 263.

Description-Dorsal line and back dark red; apical third of tail black; size large. Winter pelage-Upper parts, legs and feet yellowish gray; dorsal line dark rufous; lateral line dusky; beneath white; tail above yellowish rufous bordered with black and fringed with yellow; beneath grizzled gray. Summer pelage-Above dark olivaceous; lateral line obscure; tail like winter, but reddish, central area not well defined. (Elliot.)

Distribution-Wind River mountains north to Mystic Lake, west to head of Snake river in Idaho, south to Wasatch range, northeastern Utah.

Habits-These squirrels do not hibernate, but are active throughout the year; they accumulate at the base of a tree, under the shelter of a log, great stores of pine, spruce or other cones, sometimes in heaps containing from six to ten bushels. They also hide nuts, corn and other seeds in hollows or underground store-rooms, and sometimes lay up a half bushel or more of dried mushrooms in hollow trees. They have the greatest variety of vocal notes possessed by any members of the squirrel family. In addition to barking, scolding and chattering, they sometimes sing with longdrawn musical or churring notes. (Nelson.) Hornaday says that on their native tree-trunks these little animals are probably the most agile of our squirrels. 


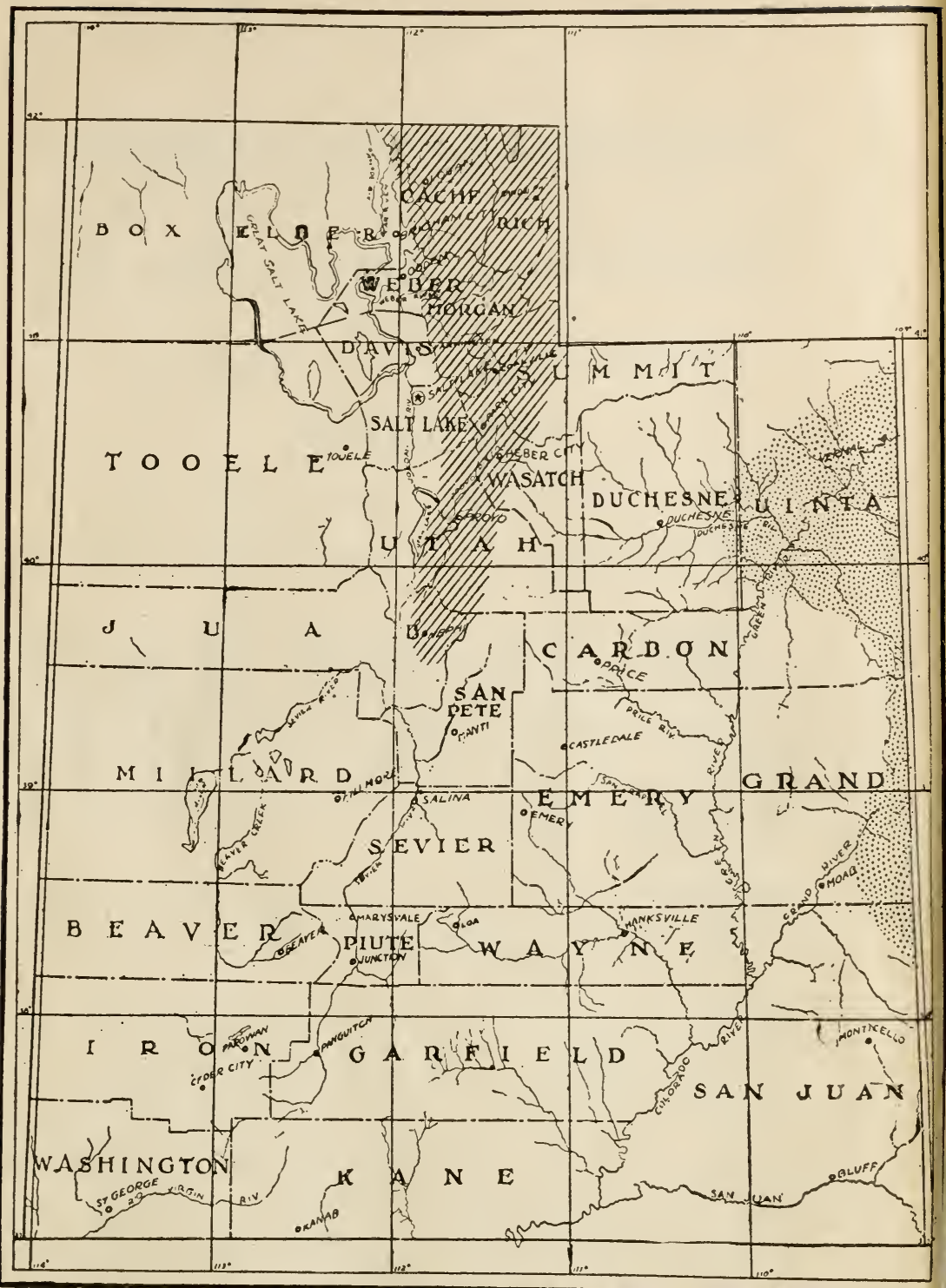

Map No. 9.-(Lined area) Range of Wind River Mountains Chickaree (SC] URUS HUDSONIUS VENTORUM Allen) in Utah. (Dotted area) Rang of Fremont's Chickaree (SCIURUS FREMONTI Aud. and Bach.) in Utal Based on E. T. Seton's map and records by Claude T. Barnes. 


\section{FREMONT'S CHICKAREE}

\section{SCIURUS FREMONTI (Aud. \& Bachm.)}

Sciurus fremonti Aud. \& Bachm. Quad. N. Am. III., 1853, p. 237.

Description-Tail shorter than the body. Ears tufted in winter, but not in summer. Above mixed brown, gray, and pale rusty, the prevalent tint similar to that of the gray squirrel; beneath bluish white, a dark line along the sides. Eyelids white. Tail entirely black at end, the hairs tipped with light grey; on other parts of the tail a mixture of plumbeous and greyish rusty at the base of the hairs. No rusty visible externally. (Baird.)

Distribution-Mountains of Colorado and the Uinta mountains, Utah, to the southern border of Wyoming.

Habits-Like the common Northern Red Squirrel, which it greatly resembles in all respects, except color, S. fremonti feeds chiefly upon pine and spruce cones, which are hoarded in large caches at the bases of trees, beneath logs, and among rocks. I have never found it living in a hollow tree, although it may do so occasionally. The nests of pine or spruce needles and fine strips of bark are usually constructed in the fork of a branch well out from the main trunk, at from 20 to 40 feet above the ground in the densest forest. I have found the nest occupied by the squirrels in both summer and winter. This squirrel is not at all shy and may be coaxed to within a few feet by making a nondescript "screeping noise." (Cary.)

\section{GILA CHIPMUNK}

\section{TAMIAS DORSALIS (Baird)}

Tamias dorsallis Baird, Proc. Acad. Nat. Scien. Phil. 1855, p. 332 .

Tamias quadrivitatus pallidus Coues and Yarr., in Wheeler's Rep. Geogr. Expl. and Surv. West of 100th Merid. V, 1876, p. 118.

Description-Sides of head with the usual stripes of Tamias, but very distinct and well defined. Above, hoary mixed with rusty and brown; beneath, dull white. Sides and buttocks dull rusty. A single distinct dorsal dark 
stripe; the others usually seen in the genus being obsolete, except the exterior light stripe, which is somewhat distinct. Tail with the vertebrae half the length of the body; the hairs unusually long, black and chestnut, largely tipped with white. Body about five inches; tail sensibly shorter. Hind foot, 1.25 inches. This species is readily distinguishable from all others by the single dorsal stripe, the others being obsolete. The more bushy tail, with its conspicuous markings of chestnut, black, and white, is also highly characteristic of it. (Baird.)

Distribution-Northern Utah to northern Mexico, west to the Sierra Nevada, east to the Nimbres in New Mexico.

Habits-The Gila chipmunk is secluded in its habits, never wandering far from its abode, which seems to be principally in the crevices of rocks. Pinions, cedar berries, and acorns are its food. (Clark.)

As a group the chipmunks are widely known for their grace, beauty of coloration, and sprightly ways. Their food includes a great variety of cultivated and wild plants, as wheat, buckwheat, corn, grass seeds, ragweed seeds, hazelnuts, acorns, strawberries, blueberries, mushrooms and many others. In addition they eat May beetles, and other insects and insect larvae, snails, occasionally frogs, salamanders, small snakes, small birds and eggs. At all seasons they fill their cheek pouches with food to be carried away to their dens, but toward the end of summer or early fall they work industriously laying up stores of seeds and nuts. Sometimes these stores, hidden in chambers excavated for the purpose or in hollow logs or similar places, contain several quarts of nuts or seeds. Small quantities of such food are hidden under leaves or in shallow pits in the ground. (Nelson.)

\section{HOPI CHIPMUNK}

\section{EUTAMIAS HOPIENSIS (Merriam)}

Eutamias hopiensis Merriam, Proc. Biol. Soc. Wash. XVIII, p. 165 (1905).

Description-General appearance of animal a lightish chestnut or rufous color; the medium dark stripe is a dark shade of the same color, with middle part of the posterior portion black; inner pair of dark stripes similar, but lack- 
ing the black, or at most it is but faintly indicated; outer pair of dark stripes nearly obsolete, just a shade darker than the color of the flanks; inner pair of light stripes not very distinct, grayish white; outer pair much whiter and clearer; rump and flanks grayish; sides of body and upper surfaces of feet light bright rufous; a distinct, large white postauricular spot and posterior half of ear whitish; light facial stripes quite white; dark ones rufous, the lower running distinctly around under ear; top of head mixed grayish and rusty, with some black hairs intermixed; below, grayish white; tail above, mixed black and chestnut; below bright chestnut with indistinct black border. Total length, 8.5 ; tail vert. 3.5 ; hind foot 1.25. (Warren.)

Distribution-Northern Arizona, southeastern Utah, southwestern Colorado and northwestern New Mexico. Several specimens have been taken at Dragon and Bluff City, Utah.

Habits-In size and general appearance the Hopi chipmunk resembles E. quadrivittatus of the eastern foothills, but its movements are more deliberate and its colors much brighter and richer. The long tail is carried more nearly horizontally even when the animal is running. This striking habit, together with the graceful downward curve of the tail near the tip, serves to distinguish it, even at a distance, from the small E. consobrinus, with which it commingles in the higher parts of its range. In the juniper country south of White river its habits of leaping up a tree when alarmed and hiding on the opposite side of a branch may cause it to be confused with the gray utahensis, which is found in similar country in the Escalante Hills. The Hopi chipmunks appear equally at home among the hot rocks in the precipitous canyons and in the dense junipers and pinon growth which clothes the bordering mesas. They feed extensively upon the berries of Juniperus monosperma throughout their range. (Cary.)

\section{UTAH CHIPMUNK}

\section{EUTAMIAS DORSALIS UTAHENSIS (Merriam)}

Eutamias dorsalis utahensis Merriam, Proc. Biol. Soc. Wash. XI, p. 210, (1897).

Description-General tone grayish above, dull mixed gray and rufous on rump; sides pale rufous or chestnut, as is also the upper surface of the foot; beneath yellowish 
white; stripes indistinct; median stripe blackish, inner dark pair grizzled, mixed blackish and rusty rufous, outer dark pair practically obsolete inner pair of light stripes grayish white, quite wide; outer pair also grayish white, but narrow; indistinct grayish white post-auricular spot; posterior half of ear grayish white; light facial stripes whitish; a rusty stripe through eye; upper and lower facial stripes mixed blackish and rufous, the latter stripe rather indistinct; top of head mixed grayish and rusty; upper surface of tail blackish, fringed with white-tipped hairs; under surface rufous, bordered with blackish. Total length 8.75; tail vert. 3.5 ; hind foot, 1.3. (Warren.)

Distribution-The type locality of this species is Ogden, Utah, though its general range extends throughout northern Utah and northwestern Nevada, throughout Arizona to New Mexico. Cary says that Utahensis has not been taken much east of Provo in Utah. It is an upper Sonoran form and probably ranges eastward along the southern foothills of Uinta mountains, entering Colorado in the region of the Yampa plateau, south of Bear River. Future work in northeastern Utah will determine whether there is a continuity of range, or the Colorado colony is entirely isolated.

Habits-These chipmunks are very wild. Their favorite feeding time is in early morning and just before sunset, when they may be found usually in the tops of junipers, busily feasting upon the berries. When frightened they utter a series of high-pitched notes, and after a hasty descent to the ground flee precipitately, rarely stopping within sight. The bushy tail is very prominent and gives the animal the appearance of a small squirrel, and this resemblance is heightened by the ease and rapidity with which it climbs trees and keeps on the opposite side from the observer. The seeds of juniper berry appear to be the chief food. (Cary.)

\section{DARK CHIPMUNK}

\section{TAMIAS UMBRINUS (Allen)}

Tamias umbrinus Allen, Bull. Am. Mus. Nat. Hist. N. Y., 1890, p. 96 .

Description-Larger than T. quadrivittatus, colors duller, and outer dark stripe obsolete. Autumn pelageAbove yellowish brown gray; flanks dull yellowish brown; 
under parts grayish white. Dark dorsal stripes black mixed with yellowish or rusty brown; outer ones usually obsolete. Light stripes pale gray, outer ones whitish. Facial streaks dusky brown and gray. Tail above orange and black; beneath orange rufous bordered with black and fringed with yellowish. (Elliot.)

Distribution-Wasatch and Uintah ranges of northern and central Utah. I found this species very common in the foothills west of Kamas, Utah, where they seemed to favor the strip of ground between a spring-moistened gully and a big wheat field.

\section{RELATED CHIPMUNK: WASATCH CHIPMUNK}

\section{TAMIAS MINIMUS CONSOBRINUS (Allen)}

Tamias asiaticus var. pallidus Allen, Mon. N. A. Roden, 1877, p. 793. (Part.)

Tamias minimus consobrinus Allen, Bull. Am. Mus. Nat. Hist. N. Y., 1890, p. 112 . Elliot, Syn, N. Am. Mamm. F. C. M. Pub. II, 1901, p. 78. Zool. Ser.

Description-A very much darker-colored animal than minimus: in midsummer pelage almost black-looking; the dark dorsal stripes are very black, with a faint edging of bright chestnut and fairly wide; the inner light stripes narrow, quite a dark gray, the outer a much lighter gray, nearer white; sides of body deep, bright rufous; flanks dark gray; upper surfaces of feet pale rufous or rusty; top of head black with gray and rufous hairs intermixed; dark facial stripes rather black; light stripes grayish, not very distinct; postauricular spot grayish white; below grayish white; tail above, black, with some rufous intermixed, below rufous with black border; the tail is thin as in E. minimus. In winter pelage the animal is grayer, and the colors are not so intense. (Warren.)

Distribution-The type locality of this species is the Wasatch foothills, near Salt Lake City, Utah. Its range extends throughout the eastern border of the Great Basin in eastern Utah, western and southern Colorado, and northwestern New Mexico.

Habits-The sharp notes of this chipmunk are characteristic sounds in the depths of the aspen and spruce forests. Deserted cabins are especially frequented by them, 
and near a camp the chipmunks soon become tame and unsuspecting. In the high country the food consists largely of wild cherries, june berries and snow berries. (Symphoricarpos oreophilus.) In the White River valley in September they were feeding extensively upon buffalo berries (Lepargyrea argentea). Cary.)

\section{BUSY CHIPMUNK}

\section{EUTAMIAS AMOENUS OPERARIUS (Merriam)}

Eutamias amoenus operarius Merrian, Proc. Biol. Soc. Wash. XVIII, p. 164, (1905).

Description-Middle, and inner pair of dark stripes quite broad and black, with indistinct rufous borders; outer pair dark stripes less distinct, mixed black and rufous; light stripes broad, and grayish white, the outer pair being the whitest; sides light rufous; flanks gray; upper surfaces of feet light dull rufous; light facial stripes grayish white; dark ones blackish; large whitish postauricular patch; below, rusty white; upper surface of tail mixed rusty and black; below, rusty white; upper surface of tail mixed rusty and black; below rufous, black bordered; the tail is much bushier than in E. minimus or E. consobrinus. Total length, 8.00 ; tail vert. 3.5 ; hind foot, 1.25 . (Warren.)

Distribution-The only record of the occurrence of this species thus far in the state of Utah is Mr. Cary's statement that he found operarius abundant in the high LaSal mountains, Utah, in July, 1907, at 11,000 feet. The species is found mostly in the state of Colorado.

\section{PAINTED CHIPMUNK}

\section{TAMIAS MINIMUS PICTUS (Allen)}

Tamias minimus pictus Allen, Bull. Am. Mus. Nat. Hist. N. Y., 1890 , p. 115.

Description-Similar to T. minimus; colors pallid. Postbreeding pelage-Above slate-gray; flanks pale yellowish buff; shoulders and hips pale slate gray. Median dark dorsal streaks black others seal brown edged with rufous; median light stripes slate gray, outer pair white. Tail above black and yellowish gray; below dark yellow buff, bordered with black and fringed with yellowish gray. (Elliot.) 
Distribution-The type locality of this form is Kelton, Utah. Its range is the western border of Great Salt Lake westward, and from southern Utah and southern Nevada to the Snake plains of eastern Washington. H. S. Rutledge and S. H. Locke say these chipmunks are very common in San Juan county.

Habits-Its home is on treeless plains, in a climate characterized by brilliant sunshine and clear, dry air. These little animals are exceedingly alert and agile, darting through dense growth of bushes with all the easy grace of weasels. When running they hold the tail stiffly erect. When alarmed they utter a shrill chippering cry, especially when darting into shelter. They also have a chucking call, uttered at intervals, which may be used merely as a note of sociability or to put their neighbors on the alert. It is most numerous on flats and foothill slopes among heavy growths of sage and rabbit brush. When its territory is invaded by settlers it does not hesitate to gather about the borders of fields and even to raid barns in search of grain and other rocks and similar shelter. In addition to seeds and green vegetation, they eat any fruits growing in their haunts, and also many insects, especially grasshoppers and larvae. They also take a web worm and its chrysalids with which the sage bushes are sometimes swarmed. The vegetable food eaten includes the seeds of Ribes, Kuntzia, Sarcobatus, pigweed, serviceberry, grasses, oats, wheat, and the seeds of small cactuses. Throughout most of their range they begin hibernation in September or October, and reappear early in Spring. (Nelson.)

\section{BEAVER VALLEY CHIPMUNK}

\section{TAMIAS LECTUS (Allen)}

Eutamias lectus Allen, Bull. Brookl. Inst. Arts \& Scien., 1, No. 5, 1905, p. 117.

Description-Post-breeding pelage-Similar in size to T. m. pictus, but colors stronger; flanks, shoulders and sides of neck, deep rufous; face stripes broader and darker, and light stripes narrower; post-auricular patch gray; central area of tail beneath bright rufous. Breeding pelageClosely resembling the coloration of 'T. cinereicollis, but distinguished from that species by the small size of the present form. 
Distribution-The type locality of this form is Beaver valley, Beaver county, Utah, and the extent of its range is not known.

Habits-It is highly desirable that this species be studied carefully by competent observers as little is known of its habits.

\section{BEAVER MOUNTAINS CHIPMUNK}

TAMIAS ADSITUS (Allen)

Eutamias adsitus Allen, Bull. Brookl. Inst. Arts \& Scien., 1, No. 5, 1905, p. 118.

Description-Similar to T. lectus in coloration, but onethird larger.

Distribution-The type locality of this species is Briggs Meadows, Beaver Range mountains, Utah, at an altitude of 10,000 feet. Its geographic distribution is unknown.

Habits-There is an excellent opportunity for someone to make a thorough study of the habits of this interesting little animal for very little is known concerning it.

\section{HARRIS' SPERMOPHILE}

\section{CITELLUS HARRISI (Audubon and Bachman)}

Spermophilus harrisii Aud. \& Bachm. Quad. N. Am. III, 1854, p. 267, pl. 144. fig. 1. Elliot, Syn. N. Am. Mamm. F. C. M. Pub. II, 1901, p. 85 . Zool. Ser.

Citellus harrisi Elliot, Mamm. Middle Amer. \& W. Indies, F. C. M. Pub. IV, Pl. I, 1904, p. 141. Zool. Ser.

Description-Tail vertebrae about half the length of the body. Ears short, pointed. Soles hairy. The upper parts generally are of a finely grizzled yellowish gray, brown and black, the color purer on the anterior portion of the back; under parts, including the tail, sides of the head, ring around the eye, and a distinct stripe on each side from the shoulders to the hips very pale brownish white; near the outside of the shoulder, arms, and legs of a pale chestnut, this color tinging the grizzled sides below the light stripe; the hairs on the thighs with paler tips and some long black 
hairs interspersed. The tail is very pale brownish white externally, then black, then white as before, and finally black on the central line; each lateral hair, therefore, having the base and sub-terminal bar black, the margin and sub-basal bar white. All the lateral hairs have a very narrow tip of black, scarcely appreciable. The whole under surface shows a uniform whitish, the concealed bases only being dusky, the basal third above is like the back. The hairs on the upper part of the body are dark plumbeous at the extreme base, then silky white for the greater part of their length, then brown, passing into black, and finally tipped with the whitish as described; interspersed are many hairs entirely black. Under the light lateral stripes, the hairs are without the dusky at the terminal portion, or only lead color and whitish. The hairs on the under parts are all plumbeous at base. Length, 5 inches; tail, with hairs, about 3. Hind foot, 1.45. (Baird.)

Distribution-Southern Utah and Nevada into California and south into Arizona, and northwestern New Mexico.

Habits-The Harris ground-squirrel inhabits the open plains, desert regions, valleys, canyons and river bottoms of Southern Utah and Arizona, usually under 5,200 feet altitude. It is fond of mesquite beans which it stores for winter use, husking the seeds before carrying them underground. It is full of playfulness and noisy activity. The rutting season extends from January to March; and the young are half grown by July. This species is to some extent carnivorous. (Mearns.)

\section{WHITE-TAILED SPERMOPHILE}

\section{CITELLUS LEUCURUS (Merriam)}

Tamias leucurus Merriam, N. Am. Faun. No. 2, 1889, p. 20.

Spermophilus leucurus Ellilot, Syn. N. Am. Mamm. F. C. M. Pub. II, 1901, p. 86, fig. 18. Zool. Ser.

Citellus leucurus Elliot, Mamm. Middle Amer. \& W. Indies, F. C. M. Pub. IV, Pt. I, 1904, p. 142 . Zool. Ser.

Description-Above, finely grizzled, the ground color varying from grayish on the anterior half of the back to pinkish vinaceous on the rump and head, and becoming salmon on the outside of the fore legs and thighs. A single white stripe on each side extends from the shoulders to the rump. Eyelids and underparts white. Tail bicolor; above, iron-gray, resulting from the fine admixture of the white 
and black annulation of the hairs, with an indistinct white border; below, clear white, with a subterminal black border more or less obscured by the underlying hairs, which are white throughout without annulations. On the upper side of the tail all the hairs are annulated. On the proximal half the lateral hairs are longer than elsewhere, the very base of each hair is white, and there are two annulations of black as in harrisi; on the distal half the base of each hair is black, with but one free black annulation. (Merriam.)

Distribution-Lower California, Mexico into California, Utah, Arizona and New Mexico. I have taken them at Beaver, Cedar City and St. George, Utah.

Habits-Merriam calls this spermophile the antelope squirrel, from the under side of the tail which is white, and becomes the most conspicuous feature of the animal as it runs swiftly away with tail cocked up over its back, after the manner of the antelope. Hornaday says that this animal is, for a spermophile, unusually fat or thick in the body.

Commonly known as the antelope, or white-tailed chipmunk, this handsome little mammal is in reality a species of spermophile, or ground squirrel. This misnomer is due, no doubt, to its small size, striped back, and sprightly ways. From the true chipmunks it may be distinguished by its heavier proportions, and from both chipmunks and all other spermophiles by its odd, upturned tail, carried closely recurved along the top of the rump. This character renders the species unmistakeable at a glance and gives it an amusing air of jaunty self-confidence. It appears equally at home skipping nimbly over rocky slopes or among slide rock in arid canyons and scurrying through the brushy growth on broad sandy plains devoid of rocks. In the higher and colder parts of their range, where snow lies long on the ground, these spermophiles hibernate for several months, but in the warmer areas they are active throughout the year. Wherever they occur they gather food and carry it to their underground store-rooms in their cheek pouches. Like most ground squirrels, they eat many kinds of seeds and fruits as well as flesh and insects. About cultivated lands they are sometimes abundant and destructive, digging up grain as soon as it is planted. They have one or more litters a season with from four to twelve young in each. (Nelson.) 


\section{LITTLE THIRTEEN-LINED SPERMOPHILE}

\section{CITELLUS TRIDECEMLINEATUS PARVUS (Allen)}

Spermophilus tridecemlineatus parvus Allen, Bull. Am. Mus. Nat. Hist. N. Y., 1895, p. 337. Elliot, Syn. N. Am. Mamm. F. C. M. Pub. II, 1901, p. 100. Zool. Ser.

Description-Striped above, six light and seven dark longitudinal stripes; the light stripes a yellowish gray color, some at least of the hairs black tipped; dark stripes a dark brown, almost black sometimes; all these stripes, except outer one on each side, have a row of spots in centre, of same color as light stripes; outer dark stripe unspotted and ill defined; top of head irregularly marked with colors of back; flanks somewhat rusty; buffy ring around eye; sides and upper surfaces of feet and under parts similar color to light stripes but somewhat lighter and more yellowish; chin whitish; tail above indistinctly banded black and yellowish white, latter color on tips of hairs, and on tip of tail; under surface of tail the same color as under part of body. Total length, 8.0 ; tail vert., 3.0 ; hind foot, 1.12. (Warren.)

Distribution-The type locality of this species is the Uncompahgre Indian Reservation, northeastern Utah, though its range extends in the near-by vicinities of Colorado and Wyoming. Its food consists of roots, green stuff, seeds, insects.

Habits-This animal is also known as "striped gopher"; it is diurnal in habits. The entrance to the burrows of these ground squirrels is about two inches in diameter. It is located usually in the midst of grass or weedy growths, and has little or no fresh earth about it. The burrow descends for several inches almost vertically and then turns almost horizontally in a sinuous and erratic crurse, with numerous branches and side passages leading up to the surface.

These squirrels hibernate throughout their range, entering their long sleep in an excessively fat condition the last of September or in October. Soon aîter they appear in spring they mate and the single litter of the year, containing from five to thirteen young, is born the last of May or early in June. (Nelson.) 


\section{SAY GROUND SQUIRREL: STRIPED SPERMOPHILE}

\section{CALLOSPERMOPHILUS LATERALIS (Say)}

Sciurus lateralis Say, Long's Exped. Rocky Mts. II, 1823, p. 46. Spermophilus lateralis Elliot, Syn. N. Am. Mamm. F. C. M. Pub. I, 1901, p. 83, fig. 17. Zool. Ser.

Description-Ears conspicuous; high. Tail, with hairs, more than half as long as head and body; depressed. Middle region of the back finely grizzled yellowish gray and black, without any lines; on each side two distinct black stripes, enclosing a yellowish white one, all of about the same diameter. Posterior half of the thigh and rump dark chestnut brown, without stripes. 'Iop of the head chestnut. Under surface of tail bright chestnut; margined with brownish yellow, within which is a black band. Length about 7 inches, tail, with hairs, about 4 ; hind foot, from heel, 1.42 inches. (Baird.)

Distribution-Colorado, Utah and Arizona. In Utah it is found frequently in the White River and Bear River districts, and on the Uncompahgre Plateau.

Habits-As its food consists largely of low, green vegetation, it is quite as terrestrial as the Harris chipmunk, seldom climbing trees, but showing great adaptability for movement amid the rocks and prostrate timber of its forest home. As one rides through the woodland it is seen perched on stones and fallen timber, or nimbly running about among the branches and decayed trunks of fallen forest monarchs. It often sits erect on its hind feet with its paws dropped by its sides, uttering a high pitched whistle which is ventriloquial in character, seeming to proceed from the nearest tree tops whilst in reality it comes from the ground at a much greater distance. The young are brought forth in June and July in burrows under logs or stones. Its nest is bulky, being composed of dry grass or any soft material at hand. (Mearns.) 


\section{WHITE-TAILED SPERMOPHILE: ANTELOPE SQUIRREL}

\section{AMMOSPERMOPHILUS LEUCURUS CINNAMOMEUS (Merriam)}

Tamias leucurus cinnamomeus Merriam N. Am. F. No. 3, p. 52, 1890.

Description-Back grizzled, black, white, and rufous; top of head rufous; very little black intermixed; a distinct white stripe on either side of back, about one-eighth of an inch wide, extending from shoulder to hip; shoulders, sides of body below stripe and flanks, and upper surfaces of feet, a light rufous or cinnamon color; light ring about eye; under surface of body white; upper surface of tail black, white edged, under surface white, mixed black and white border and tip. Total length, 8.50; tail vert. 2.50; hind foot, 1.60. (Warren.)

Distribution-White River, Grand River, and streams tributary to the Colorado and Green Rivers. It also occurs in northern Arizona, southern Utah, southwestern Colorado and northeastern New Mexico. S. H. Locke says they are common in the desert region about LaSal National Forest.

Habits-Antelope squirrels frequent sandy arroyos and are striking objects as they frisk about in the morning sunshine with the pure white under surface of the upraised tail showing prominently. They are easily alarmed and retreat precipitately to the burrows, which are usually in the sandy bank of a dry desert wash or beneath sage or Atriplex bushes. (Cary.)

\section{CHESTNUT-TAILED SPERMOPHILE}

\section{CITELLUS CASTANURUS (Merriam)}

Tamias chrysodeirus Merriam, N. A. F. No. 4, 1890, p. 19. Spermophilus chrysodeirus Elliot, Syn. N. Am. Mamm, F. C. M. Pub. II, 1901, p. 84. Zool. Ser.

Description-Color: Head and neck to shoulders ferruginous chestnut, lightest on the sides of the neck. Inner black stripe nearly as broad, long and sharply defined as the outer, in this respect resembling $\mathbf{T}$. chrysodeirus of the Wasatch. Belly hairs dusky at base as in T. chrysodeirus, but 
tipped with whitish or very pale yellowish, the dusky base showing through. Tail above mixed yellow, black, and reddish brown, with yellow or fulvous border; tail below deep chestnut, with a submarginal black band. Upper surfaces of feet whitish. The ground color of the rump and outer side of the leg is darker and more strongly suffused with reddish-brown than in T. chrysodeirus. (Merriam.)

Distribution-The type locality of this species is Park City, Utah, (altitude 7,000 feet). Its range extends generally throughout the Wasatch mountains.

Habits-These ground squirrels are particularly abundant around Park City, and around the boarding-houses at the mines, where they pick crumbs about the doors. A good many live along the roads, picking up the grain that falls from wagons. Of thirty-five stomachs examined, all but ten contained remains of insects (grasshoppers, beetles, flies, and larvae). Most of them contained also seeds of plants, flowers, and foliage, and some were nearly full of roses. Many contained corn, beans, oats, bread, cake, potatoes, and fat pork picked up about camp. (Bailey.)

\section{TOWNSEND'S SPERMOPHILE}

\section{CITELLUS TOWNSENDI (Bachman)}

Spermophilus townsendii Bachm. Jour. Acad. Nat. Scien. Phil. 1839 , p. 61.

Description-Ears obsolete; tail cylindrical, very short, with the hair, scarcely twice the length of hind feet. Above, dark brown, with numerous obsolete and crowded light spots; belly whitish. Length about 7 inches; tail less than 2 inches; hind foot, 1:30. (Baird.)

Distribution-Nebraska westward to the plains of the Columbia River and from Wyoming and Utah to Montana, Idaho and Oregon.

\section{KENNICOTT'S SPERMOPHILE}

\section{CITELLUS MOLLIS (Kennicott)}

Spermophilus mollis Kennicott. Proc. Acad. Nat. Scien. Phil. 1863, p. 158.

Description-Form stout; muzzle short, compressed, ears rudimentary ; feet large, claws weak, compressed. Above 
variegated silvery gray, yellowish brown and black under parts silvery gray washed with creamy yellow. Tail above yellowish brown, mixed with black, bordered and tipped with white; below reddish brown fringed with white. (Elliot.)

Distribution-The type locality of this species is Camp Floyd, Utah; and though it extends into Nevada the exact range of this spermophile is not fully determined.

\section{ARMED SPERMOPHILE}

\section{CITELLUS ARMATUS (Kennicott)}

Spermophilus armatus Kennicott, Proc. Acad. Nat. Scien. Phil. 1863, p. 158.

Description-Stout; ears large; feet large ; tail short, bushy; pelage soft. Above dark gray and black, washed with brown on middle of the back; shoulders, rump and thighs ochraceous brown. Under parts silvery gray tinged with yellowish, dark bases of hairs showing through. Tail, above and below mixed gray and black, subterminal black border, and black tip edged with gray. (Elliot.)

Distribution-The type locality of this species is Fort Bridger, Utah, though the geographic distribution of this spermophile includes parts of Utah, Wyoming, Idaho, and Montana, the precise range having as yet been undetermined.

\section{ELEGANT SPERMOPHILE}

\section{CITELLUS ELEGANS (Kennicott)}

Spermophilus elegans Kennicott, Proc. Acad. Nat. Scien. Phil. 1863 , p. 158.

Spermophilus richardsoni var. townsendi Allen, Mon. Rod. 1877, p. 848 (nec. Bachm.).

Description-Upper parts brown, with an indistinct mottled or spotted appearance caused by the tips of the hairs being black; in some lights the animal seems to be transversely crossed by narrow irregular wavy black lines; top of head like but without the spotted appearance; caused by the tips of the hairs being black; in some lights the animal seems to be transversely crossed by narrow irregular wavy black 
lines; top of head like back but without the spotted appearance; sides, flanks, and upper surface of feet pale fulvous; underparts (except chin) a somewhat paler shade of fulvous; chin whitish; light whitish buff ring around eye; tail above mixed brown and black, tip black edged with whitish; below brown or fulvous, about like sides, with black tip. Specimens in spring, in worn pelage, are somewhat grayer and paler. Total length, 10.8; tail vert. 3.0 ; hind foot, 1.75 . (Warren.)

Distribution-The type locality of this species is Fort Bridger, Wyoming and its range includes the northeastern part of Utah

\section{UTAH SPERMOPHILE}

\section{CITELLUS VARIEGATUS UTAH (Merriam)}

Citellus variegatus utah, Merriam, Proc. Biol. Soc. Wash. XVI, 1903 , p. 77.

Description-Like grammurus except that the rufous is somewhat darker and more intense. The tail is somewhat longer in proportion.

Distribution-The type locality of this species is the foot of the Wasatch mountains, near Ogden, Utah. It extends eastward to Colorado, being found only in these two states.

Habits-The habits of utah are the same as those of grammurus.

\section{ROCK SQUIRREL}

\section{CITELLUS VARIEGATUS GRAMMURUS (Say)}

Sciurus grammurus Say, in Long's Exped. Rocky Mts. II, p. $72,1823$.

Spermophilus grammurus, Bach. Charlesworth's Mag. Nat. Hist., 111, 1839, p. 390.

Description-Body thick, clumsy; about the size of Sciurus cinereus; vertebrae of tail about three-fifths of length of the body. Ears broad and high. Palms and soles entirely smooth. The anterior half of the body, above and on the sides, is of a rather pure black and white mixed, 
the subterminal portion being grayish white; the basal and terminal black. The basal fur above is black, laterally it is of a bluish ash. On the posterior half of the body the white is replaced by pale yellowish brown, and the black by a dark brown. On the sides the colors are purer, the hairs becoming lighter at the base in passing down the sides and to the root of the tail. The under parts are of a pale fulvous white, changing into pale brownish yellow anteriorly, posteriorly, and on the inner faces of the limbs, the hairs being everywhere brown at the base, except on the last mentioned region. The top and sides of the head are grayish white and black, mixed, the latter predominating. The eyelids are white; the exterior surface of the ear is brownish yellow, as is the posterior border of the inner surface; the remainder is dark brown. The tail is white and black, the former predominating and constituting rather a broad border all round; there are three distinct rings of black, the outer and sub-terminal one broadest. In some specimens the white appears more or less soiled. Body about 12 inches; tail with hairs 9 ; hind feet 2.25. (Baird.)

Distribution-The type locality of this species is Purgatory river, Las Animas, Colorado. It extends into Utah along the Grand River. Specimens have been taken from the Book-Cliff mountain region.

Habits-Rock squirrels nearly always live in rocky situations, such as the ledges and boulder-strewn sides of canyons, the bare rocky slopes along the base of the foothills, and the rim rock of outlying mesas and buttes being especially frequented. Rock squirrels are quite shy and wary, and when one is surprised in the bottom of a canyon, as is often the case, it invariably runs up the slope and takes refuge among the rocks above. If the observer remains perfectly quiet, he may at length detect the animal peering silently over the top of a large boulder, but it generally vanishes at the slightest noise or motion. I watched one of these squirrels dusting itself near Bayfield. Apparently it was unaware of my presence and at intervals would run to a dusty spot in a path, throw the dust up with its fore feet, turn on its back, and wriggle and squirm along the ground in the greatest enjoyment. This performance was repeated a number of times, when suddenly the little fellow spied me and raced off through the brush. The food of rock squirrels consists chiefly of pinyon nuts, acorns, and juniper berries, and consequently over much of their range the animals do little damage. (Cary.) 


\section{WHITE-TAILED PRAIRIE-DOG}

\section{CYNOMYS LEUCURUS (Merriam)}

Cynomys columbianus Allen, Proc. Boston Soc. Nat. Hist., XVI, p. 294 (part; not Arctomys columbianus Ord. 1815). 1874.

Cynomys leucurus Merriam, North Amer. Fauna No. 3, p. 59, September 11; North Amer. Fauna No. 4, p. 33, October 8, 1890.

Cynomys lewisii Allen, Bull. Amer. Mus. Nat. Hist. X, p. 456, November 10, (not Arctomys lewisii Audubon and Bachman, 1854) 1898.

Cynomys lewisi Trouessart, Cat. Mamm., suppl., p. 342. 1904.

Description-Adult in fresh summer pelage: General color of upper parts yellowish buff, streaked with blackish. Nose yellowish buff, unmarked; spot above eye and large area on cheek dark blackish brown; ears pale cinnamon. Top of head to center of tail uniformly mixed pale cinnamon-buff or yellowish buff and blackish; the individual hairs black at bases, then light gray, then pale cinnamon, with subterminal band of buff and, in unworn condition, tip of blackish. Limbs, feet, and underparts clear buffy; nails blackish, tipped with light horn. Tail white, the hairs of proximal half above with bands of blackish, below pale cinnamon; distal half clear white. Adult in fresh winter pelage: Decidedly darker than in summer; more blackish above, especially posteriorly; the buff tints richer in tone and the dark areas on head considerably spread out, less sharply defined. There is a heavy underfur of grayish white, but the bases of all the hairs are clear black; sides of nose, chin, and throat white; nape and flanks lighter, more grayish, than back and rump. Juvenile pelage: Above grayish brown; below paler grayish; supraorbital spot of brownish black sharply marked. Postjuvenile pelage: Specimens in first fresh autumnal coat darker than adults, more reddish, and hairs of upper parts more heavily tipped with blackish. Adults in the faded, left-over winter coat are often very yellowish above, with little or no black streaking from the hair tips. Many specimens in various stages of molt and renewal present strange combinations of color. Examples deeply stained by color from the soil are frequently noted. (Hollister.)

Distribution--Irregular areas in the mountainous parts of Montana, Wyoming, Utah and Colorado. In this state it occurs mostly in the extreme northern part and in the Green River Valley. Specimens have been taken in the Uinta mountains and in the Uncompahgre Indian reservation. 
Habits-The White-tailed Prairie Dogs are very injurious to green crops, as they frequently destroy cabbages, cantelopes and other truck farm products. They do considerable damage to range grasses and alfalfa fields. While eating they sit erect on their hind legs, but if disturbed, run to their burrows, carrying the food in their mouths. (Cary.)

Owing to the constant danger to which they are subject from coyotes, foxes, bobcats, and badgers, in addition to eagles and other birds of prey, prairie dogs are constantly on the alert. At any suspicious occurrence the first to observe it runs to his entrance mound, if the danger is not pressing, but otherwise to the nearest mound, where he sits up at his full length, "barking" and vibrating his tail, ready, if necessary, to disappear instantly. At the same time the "town" is alive with scurrying figures of the inhabitants rushing to their homes. (Nelson.)

\section{UTAH PRAIRIE-DOG}

\section{CYNOMYS PARVIDENS (Allen)}

Cynomys parvidens Allen, Science Bull., Mus. Brooklyn Inst. Arts and Sci., I, No. 5, p. 119, March 31, 1905.

Description-Adult in late summer: Entire upper parts of head and body cinnamon or dark buffy cinnamon, with very little admixture of buff or blackish hairs; the individual hairs blackish at bases, then narrowly pale buff, broadly cinnamon, and tipped with dark brown. Spot of black above eye very sharply marked; cheek patch of brown distinct; sides of nose pale buff; eye ring ,ears, and limbs cinnamon; feet dark buff; lips and chin whitish; underparts buffy or cinnamon. Tail for half its length above concolor with rump; below cinnamon terminal half all around white, without markings. Adults in early winter pelage: In general like summer coat but with dense underfur which is black at base, then light buff; upper parts rich cinnamon, the long hairs with broad bands of black and buff; sides of body yellowish buff, distinctly marked from color of back, and streaked by the bands of black on the longer overlying hairs.

Distribution-Mountain valleys of central Utah in the Sevier River region; south from Nephi to Iron and Garfield counties. Several specimens have been taken from Buckskin Valley and the Sevier National Forest. 


\section{ZUNI PRAIRIE-DOG}

\section{CYNOMYS GUNNISONI ZUNIENSIS (Hollister)}

Cynomys Gunnisoni Zuniensis-Hollister, N. A. Fauna, No. 40, 1916, p. 32.

Description-Adult in fresh summer pelage: General color of upperparts pale cinnamon, heavily streaked with lighter cinnamon-buffand blackish; individual hairs blackish at bases, then narrowly buff, then broadly cinnamon, with subterminal band of buff, and tip of blackish. Nose, lips, eye ring, and ears, buff; between eyes, between ears, and over nape darker brown, mixed with blackish ; large area of blackish brown on cheek, and a smaller, sharply marked, blackish brown spot above eye; feet, limbs, and underparts pale cinnamon-buff. Basal half of tail above concolor with back; distal half mixed gray and white, bordered and tipped with clear white. The black tips to the hairs of the back rapidly wear away and the pelage becomes a uniform dull cinnamon, mixed with light buff. The distinctive markings of the head become more obscure. Adult in fresh full winter pelage: General color more grayish and buff, less cinnamon, than in summer, with greater admixture of blackish hairs on head and more of white and gray on body. General color of upper parts dark cream-buff, heavily mixed with pale buff and blackish, giving a decided grizzled appearance; underfur narrowly black, then broadly whitish; the long hairs with bands of black, pale cinnamon, and white, and narrow tips of black. Top of head and cheeks heavily intermixed with blackish, the spot over eye sometimes intense black; sides of nose, eye rings, ears, limbs and sides of body rich cream-buff; lips and throat paler; underparts pale cinnamon. Tail above mixed gray and white, with a narrow sub-border of dark gray and border of clear white; below clear pale cinnamon, terminal half with faint sub-border of grayish brown and border and tip of creamy white. Young examples in the fresh postjuvenile pelage are more vinaceous or pinkish cinnamon than the corresponding pelage of C. g. gunnisoni. (Hollister.)

Distribution-Extreme southeastern Utah.

While in the main an Upper Sonoran form, this prairiedog is generally distributed in the Transition Zone parks of numerous mountain ranges. 


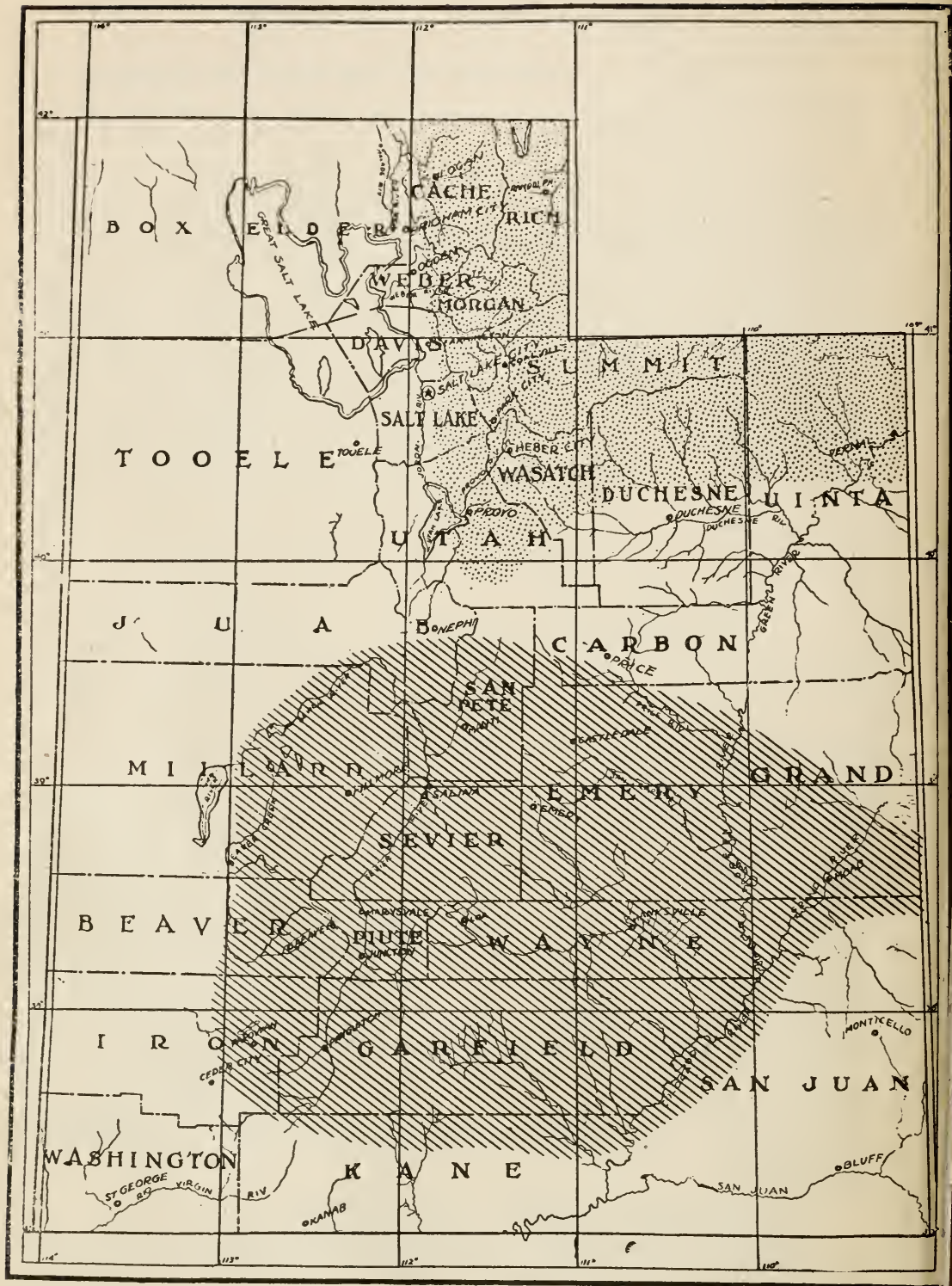

Map No. 11.- (Lined area) Range of Engelhardt Marmot (MARMOTA FLA VIVENTRIS ENGELHARDTI Allen) in Utah. Dotted area) Range o Golden-mantled Marmot (MARMOTA FLAVIVENTRIS NOSOPHOR Howell.) Based on map of A. H. Howell and records by Claude T. Barne: 


\section{ENGELHARDT MARMOT: HOARY MARMOT}

\section{MARMOTA FLAVIVENTRIS ENGLEHARDTI (Allen)}

Marmota engelhardti Allen, Mus. Brooklyn Inst. Arts \& Sci., Sci. Bul., I, 1905, p. 120.

Description-General tone of upper parts vandyke brown, grizzled with buffy white; underfur fuscous at base succeeded by pinkish buff or pinkish cinnamon, the latter shading on sides to Rood's brown; long hairs blackish brown, tipped with light buff or buffy white; top of head and face blackish brown, with an irregular white patch in front of eyes; sides of head mixed brown and buffy white; sides of neck with a small area of ochraceous-buff; legs and feet hazel, tail above dark clove brown, tipped with hazel; beneath, blackish brown; underparts hazel or ochraceoustawny, the bases of hairs blackish brown; sides of nose, lips, and chin, white.

Distribution-Beaver and Parowan mountains; southern Utah; also Midvale, Idaho. Exact limits of range unknown. The type locality of this species is Briggs meadow, Beaver range, Utah. (Altitude 10,000 feet.) Several specimens have been taken from Beaver mountains and Parowan mountains.

Brigham Spencer informs me that woodchucks are quite numerous in Wayne, Garfield, Emery, Grand and San Juan counties. B. E. Mattsson says woodchucks are numerous in the Manti forest, while J. W. Humphrey of Panguitch informs me that they may be found by the hundreds on all portions of the Sevier forest. George E. Barney of Escalante reports that they are numerous in the lava beds of the Escalante forest district. C. A. Mattsson of Salina writes as follows: "The immense lava deposits which extend south of the Salina creek watershed to the extreme southern boundary of the Fishlake forest provide a suitable habitat for woodchucks. These animals are numerous in these lava beds and are often seen by persons riding the range. The homes of the woodchuck in this locality is on areas having an elevation of over 7,500 feet, and they are most numerous in the lava beds having an elevation of about 8,000 feet." S. B. Locke says they are well distributed in the high LaSal mountains.

Habits_Though a forest animal, the woodchuck nevertheless prefers the edges of sunny openings to the dismal depths of the woodland; and in Utah he burrows almost ex- 
clusively in high dry places, the verdant clay banks and the wooded gravelly ridges of the upper mountains. While provender is good the woodchuck ordinarily does not stroll more than one hundred yards from home, though at times when food is scarce he may in the day or at night go a mile or more to new fields. This is the only.migration known of the species.

When chased the woodchuck rushes into its burrow, digs a new side tunnel and fills the entrance behind him. He is a most sanitary animal for, during the winter, all excrement is hidden in a dry earth chamber in the den, and, in summer, a midden heap as big as a half bushel measure is gradually formed at the entrance to the burrow.

Seldom, except during the voluptuous activity of early spring, does a grown woodchuck have any adult companions in the burrow. Mating takes place in the middle of March, though there is some evidence of pairing in the autumn.

The young, two to eight, but usually four or five, are born in April and are blind until one month old. Being full grown at the end of August they issue forth and build a number of holes near by.

In the autumn old and young prepare for winter by eating until they are so fat that they can hardly waddle. The winter nests are warmly lined but no food is stored away in them. Towards the last of September the woodchucks curl up in winter sleep, never emerging except in exceptional weather.

Being partial to twilight the woodchuck rambles usually when the moon is shining. He is slow on foot and in an emergency relies on reaching his burrow. He can climb a tree though not so cleverly as can a porcupine, or squirrel, and never without a running start. He swims poorly and like a rabbit does not drink, depending on dews and plant juices.

When cornered a woodchuck will whistle an alarm, and grate its teeth so hard that splinters may fall.

\section{GOLDEN-MANTLED MARMOT}

\section{MARMOTA FLAVIVENTRIS NOSOPHORA (Howell)}

Marmota flaviventer nosophora, Howell, Proc. Biol. Soc. Washington, XXVII, 1914 , p. 15.

Description-Underfur of upper parts at base blackish brown on forepart of body, becoming fuscous on hinder 
parts, succeeded by a broad area of whitish buff (tilleul buff of Ridgway) shading (on hinder back) to pinkish cinnamon or pale russet; long hairs black subterminally, broadly tipped on forepart of back with warm or ochraceous-buff and on hinder part with white or buffy white; top and sides of head blackish brown, with a conspicuous band of white or buffy white across face in front of eyes; sides of face mixed with cinnamon or white; sides of nose, lips, and chin white or buffy white; sides of neck with ochraceous-buff patches behind ears; fore legs kaiser brown; hind legs and rump warm buff; hind feet hazel to russet; tail chestnutbrown or blackish brown, varied with hazel or cinnamon-buff (fading to dull cinnamon or clay color); underparts hazel shaded with kaiser brown, becoming bright chestnut on throat and sometimes on belly. Variation: A dark, brownish color-phase occurring rarely, and seemingly most frequent at high altitudes, may be described as follows: General tone of upper parts dark brown grizzled with white; underfur at base mouse gray (shading on hinder back to fuscous) succeeded by buffy white (shading on hinder back to light pinkish cinnamon); long hairs blackish brown, tipped with white; top and sides of head blackish brown; underparts mixed blackish brown and pinkish buff in about equal proportions; throat shaded with russet; feet and tail blackish brown; legs brownish mixed with ochraceous-tawny. (Howell.)

Distribution-Rocky mountain region of Montana, Idaho, and Wyoming, from Flathead Lake, Mont., south to the Wasatch mountains, Utah, and east to the Bighorn mountains, Wyo.; altitudinal range from about 3,000 to 11,800 feet. Specimens have been taken in Utah from Blacksmith's Fork, Laketown and Park City. This species intergrades with engelhardti. They are quite common in the Wasatch mountains.

Habits-The Golden-Mantled Marmot is in this State known usually as the woodchuck, rockchuck or groundhog. It lives usually on rocky hillsides, in the crevices of cliffs, or beneath rock piles in meadows. The flesh of this animal is palatable. It subsists chiefly on grass, tender leaves and the stems of native plants. "Groundhog day" is a myth based on no scientific facts. 


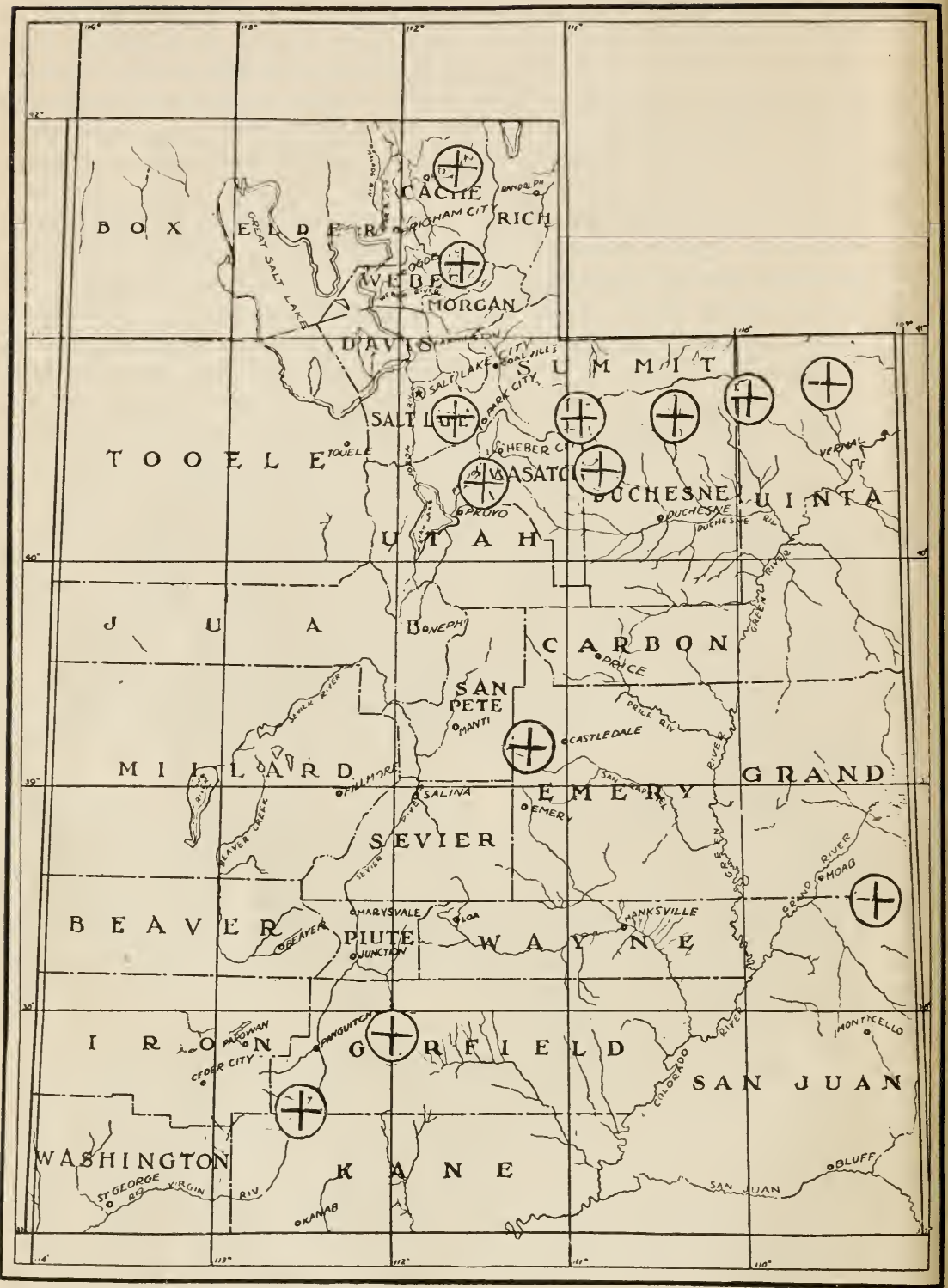

Map No. 12.-Range of Sonoran Beaver (CASTOR CANADENSIS FRONDATOR Mearns) in Utah. Based on records by. Claude T. Barnes. 
Family CASTORIDAE. Beavers

\section{SONORAN BEAVER: BROAD-TAILED BEAVER}

\section{CASTOR CANADENSIS FRONDATOR (Mearns)}

Castor Canadensis Frondator, Mearns, Pros. U. S. Nat. Mus., 1897, p. 502.

Description-Above, dark red brown, bright and glossy in certain lights, under fur dusky black; sides and head paler; upper surfaces of feet chocolate; underparts similar, but a somewhat lighter shade. Total length, 41.5; tail vert., 14.0 ; hind foot, 7.2 ; scaly portion of tail, $11.3 \times 4.8$.

Distribution-The beaver was undoubtedly at one time very common in the State of Utah. Mr. George B. Hancock informs me that many old dams now exist on Hunt Creek, a branch on the east fork of the Sevier River, Garfield county. A few are still to be found, according to B.E. Mattsson, in Fish and Huntington creeks, Manti forest. J. W. Humphrey of Panguitch says: "The beaver under the protection afforded them by the state have become so numerous on the headwaters of the Sevier river that they are some. what of a nuisance and do considerable damage along the canals." E. C. Shepard says that there are a few in Logan canyon. William M. Anderson of Vernal informs me: "Beaver are very plentiful. There are thousands of them on the streams. To such an extent are they increasing that it has become necessary to trap them out in some instances." Though many streams of the Fishlake forest are named after the beaver, none exist there now according to C. A. Mattsson. George H. Barney of Escalante reports that there are a few on North Coyote, Mamie, and Boulder creeks in the Escalante forest. There are three colonies, the remainder being individuals. A. W. Jensen of Provo estimates that there are 400 beavers in the Uintah forest district.

Mr. F. A. Wrathall informs me that he has seen the fresh workings of the beaver in nearly all of the streams of the Wasatch mountains and that the animals are very common in Gooseberry Creek at the head of the Weber river. They are also reported as building a dam at Upper Falls in Provo canyon where thousands of fishermen visit in the summer.

S. B. Locke says that beavers occur along LaSal creek and tributaries on the east side of the LaSal mountains into Colorado. They there interfere to some extent with irrigation works. 
Family MURIDAE. Rats, Mice, Voles

Subfamily MAURINAE

\section{BLACK RAT}

\section{MUS RATTUS (Linn)}

Mus rattus, Linnaeus, Syst. Nat., 10th ed., 1758, p. 61; Elliot, F. C. M., 11, 1901, p. 117, fig. 28 (skull), Syn. Mam. N. Am. IV, 1904 , p. 163, fig. 31 (skull), fig. 25 (animal); Miller and Rehn, Proc. Bost. Soc. Nat. Hist., XXX, No. 1, Dec. 27, 1901, p. 56.

Description-The black rat is usually of a sooty or plumbeous black color, paler on the underpart.

Distribution-The black rat now appears in nearly all of the older portions of Salt Lake City and adjacent lowlands. It is especially common along the Jordan river and in the western part of the city. Its range is gradually extending. It everywhere does damage of almost every conceivable type, its ravages on the poultry farms being particularly noticeable.

\section{NORWAY RAT: BROWN RAT}

\section{MUS NORVEGICUS (Erxleben)}

Mus norvegicus Erxleben, Syst. Regn. Anim., 1777, p. 381.

Mus decumanus Pall., Nov. Sp. Quad. Glir., 1778, p. 91.

Description-The brown rat differs from the other two species in America in larger size, shorter head, more obtuse muzzle, smaller ears, and relatively shorter tail. The general color is grayish brown above and whitish below. The overhairs of the upper parts have black tips. The tail is usually shorter than the head and body combined, while in the other two species it is generally longer. Total length, 12.0; tail vert., 5.6; hind foot, 1.5. (Lantz.)

Distribution-The brown rat has unfortunately of recent years become very common in Salt Lake City; and its range is gradually extending along railway lines.

Habits - The marvelous rapidity with which brown rats increase is shown from the fact that nests, though usually containing about eight young, have been found with twentythree young ones in them; and a new litter is brought in 
every seventy-five days under the most favorable conditions. Young females have been known to have their first litter when only 103 days old. It has been estimated that under ideal conditions the uninterrupted breeding of a single pair of rats would in three years' time result in the incredible number of 20,185,392 individuals. Of course, such results never happen in nature where various enemies are constantly to be considered; but it is sufficient warning to those who have heretofore paid no attention to the increase of brown rats in Utah.

These facts should be borne in mind by everyone: $\mathrm{Bu}-$ bonic plague in man is entirely dependent on the disease in the rat; the infection is conveyed from rat to rat and from rat to man by means of the rat flea; insanitary conditions have no relation to the occurrence of the plague except so far as they favor the infestation by rats.

Skunks, weasels and minks destroy rats; and rat-proof buildings can easily be constructed, the concrete footing being the most important factor. Rats are practically omnivorous, a few of the things they readily devour being the following: seeds, grain, flour, meal, food, fruit, vegetables, mushrooms, bark, bulbs, roots, stems, leaves, flowers, eggs, chicks, ducklings, young pigeons, rabbits, milk, butter, cheese, meat, carrion, mice, rats, fish, frogs, and mussels. (Lantz.)

Before it is too late every effort should be spent to eradicate this pest, for one must not forget the millions of dollars it cost San Francisco to overcome them.

\section{HOUSE MOUSE}

\section{MUS MUSCULUS (Linnaeus)}

Mus musculus Linn., Syst. Nat. I, 1758, p. 62; I, 1766, p. 83.

Description-Above, grayish brown (mouse color), lined with blackish ; beneath, ashy plumbeous, tinged with reddish. Tail dusky; feet ashy brown. Total length, 6.5 ; tail vert. 3.2 ; hind foot, 0.70 . (Warren.)

Distribution-The house mouse is common in all settled vicinities of the State. 
Subfamily CRICETINAE

\section{BLACK-BROWED MOLE MOUSE}

\section{ONYCHOMYS MELANOPHRYS (Merriam)}

Onychomys leucogaster melanophrys Merr., N. Am. Faun. No. 2,1889 , p. 2 .

Onychomys melanophrys Elliot, Mamm. Middle Amer. \& W. Indies, F. C. M. Pub., IV, Pt. I, 1904, p. 166. Zool. Ser.

Description-Hind foot densely furred to base of toes. Color above, rich tawny cinnamon, well mixed with blacktipped hairs on the back, and brightest on the sides; a distinct black ring round the eye, broadest above. This ring is considerably broader and more conspicuous than the very narrow ring of leucogaster. (Merriam.)

Distribution-The type specimen of this species was collected at Kanab, Utah, December 22, 1888, by Vernon Bailey. The exact limits of its range are unknown. Doctor Merriam calls it the Black-eyed Grashopper Mouse.

\section{LONG-TAILED GRASSHOPPER MOUSE}

\section{ONYCHOMYS LONGICAUDUS (Merriam)}

Onychomys longicaudus Merr., N. Amer. Faun, No. 2, 1889, p. 2 .

Description-General color above, cinnamon-fawn, well mixed with black-tipped hairs.

Distribution-The type specimen of this species was taken at St. George, Utah, January 4th, 1889, by Vernon Bailey. The limits of its range are unknown.

Habits-The grasshopper mice are notable for the delicate coloring and velvety quality of their fur. While closely resembling some of the white-footed mice, they may readily be distinguished from them by more robust form, short, thick tail, and the character of the fur. They live in burrows and sometimes evade the labor of digging them by occupying the deserted holes of mice, kangaroo rats், ground squirrels, prairie dogs, badgers and other animals. Their bill of fare includes a miscellaneous assortment of several species of 
mice, including their own kind caught in traps, small dead birds, lizards, frogs, cutworms, scorpions, mole crickets, ordinary crickets, grasshoppers, moths, flies, and beetles, including the potato bug. In addition to these, they eat seeds, fruits and vegetable matter.

\section{TAWNY FIELD MOUSE}

\section{PEROMYSCUS RUFINUS (Merriam)}

Hesperomys leucopus rufinus Merr., N. Am. Faun. No. 3, 1890 , p. 65.

Peromyscus rufinus Elliot, Syn. N. Am. Mamm., F. C. M. Pub. 11, 1901, p. 126.

Hesperomys leucopus sonoriensis, Mearns, Bull. Am. Mus. Nat. Hist., 11, Art. XX, Feb. 21, 1890, p. 284.

Description-Upper parts, deep tawny brown, darkest along the middle of the back, and brightest along the sides, the body color reaching to the elbows and heels; under parts including feet, white; tail, sharply bicolor, dusky above, whitish below; ears dark. (Merriam.)

Distribution-Northwestern Arizona to New Mexico, Utah, and Colorado.

Habits-This beautiful mouse is actually a forest animal, living in the pine, aspen and Douglas spruce woods. It frequents camps and cabins.

\section{SUBARCTIC FIELD MOUSE}

\section{PEROMYSCUS TEXENSIS SUBARCTICUS (Allen)}

Peromyscus texanus subarcticus Allen, Bull. Am. Mus. Nat. Hist. N. Y., 1899, p. 15.

Peromyscus texensis subarcticus Elliot Syn. N. Am. Mamm. F. C. M. Pub. ii, 1901, p. 131.

Description-Above dusky brown, tinged with pale fulvous, blackish on median line; fulvous on flanks; feet and under parts white. Tail above blackish brown, sides and beneath white. (Elliot.)

Distribution-From Utah and Colorado, through Wyoming, the Dakotas and Montana to the Saskatchewan Valley, Alberta. 


\section{ROWLEY CLIFF MOUSE: ROWLEY'S FIELD MOUSE}

\section{PEROMYSCUS BOYLEII ROWLEYI (Allen)}

Sitomys rowleyi Allen, Bull. Am. Mus. Nat. Hist. N. Y. 1893 , p. 76.

Peromyscus rowleyi Elliot, Syn. N. Am. Mamm. F. C. M. Pub., II, 1901, p. 134. Zool. Ser.

Description-Above, brown, dorsal region with many black and a few white hairs intermixed. Upper surface of the tail like the back. Feet and under parts white. Total length, 7.25 ; tail vert., 3.6 ; hind foot, 0.8 . (Warren.)

Distribution-The type locality of this species is Nolan's Ranch, San Juan County, Utah. The species occurs throughout southeastern Utah.

Habits-The Rowley Cliff mouse inhabits rock ledges and cliffs in the juniper belt, its food consisting chiefly of juniper berries.

\section{GOLDEN-BREASTED MOUSE: GOLDEN- BREASTED CANYON MOUSE}

\section{PEROMYSCUS CRINITUS AURIPECTUS (Allen)}

Sitomys auripectus Allen, Bull. Am. Mus. Nat. Hist. N. Y. 1893 , p. 75.

Peromyscus auripectus Elliot, Syn. N. Am. Mamm. F. C. M. Pub., II, 1901, p. 134. Zool. Ser.

Description-Hair long and silky; above bright buff or tawny, lightest on the sides and flanks, a slight admixture of black hairs in the dorsal region. Feet and under parts white, except yellow spot on breast between fore legs. Tail with distinct pencil; upper part quite dark. Total length, 6.8 ; tail vert., 3.5 ; hind foot, 0.8 . (Warren.)

Distribution-The type locality of this beautiful mouse is Bluff City, Utah, on the San Juan River. It inhabits the rock ledges and cliffs in much of the rough canyon and mesa country. (Cary.)

Habits-The Golden-breasted canyon mouse, easily distinguished by its yellow breast spot, inhabits ledges and cliffs in the canyon and mesa district in southeastern Utah. 


\section{TRUE'S MOUSE: TRUE'S DEER MOUSE}

\section{PEROMYSCUS TRUEI (Shufeldt)}

Hesperomys truei Shufeldt, Proc. U. S. Nat. Mus. 1886, p. 407, pl. XXI, figs. $1,5,8$.

Peromyscus truei Elliot, Syn. N. Am. Mamm. F. C. M. Pub., II, 1901, p. 139 . Zool. Ser.

Description-Fur moderately long and silky. Upper parts a pale brown, darkest on back caused by a slight mixture of black hairs. Feet and under parts white. Tail with distinct pencil; upper part blackish. Ears very large, 1.0 in specimen described. Total length, 7.25; tail vert., 3.5; hind foot, 0.95. (Warren.)

Distribution-True's mouse is found throughout Nevada, Utah and New Mexico, its range being practically coextensive with the juniper and pinyon belt.

Habits-True's deer-mouse, easily distinguished by its protruding eyes and immense ears, inhabits rocky places and subsists chiefly on juniper berries, seeds and insects.

\section{DESERT HARVEST MOUSE}

\section{REITHRODONTOMYS MEGALOTIS MEGALOTIS (Baird)}

Reithrodon megalotis Baird, Mamm. N. Am., 1857, p. 451.

Reithrodontomys megalotis Allen, Bull. Am. Mus. Nat. Hist. V. 1893 , p. 79 ; VII, 1895 , p. 125.

Reithrodontomys megalotis deserti Allen, Bull. Am. Mus. Nat. Hist. VII, 1895, p. 127 (Oasis Valley, Nev.).

Reithrodontomys megalotis sestinensis Allen, Bull. Am. Mus. Nat. Hist. XIX, 1903, p. 602, (Rio Sestin, northwestern Durango).

Description-Color, unworn winter pelage: upper parts mixed blackish brown and light ochraceous-buff, darkest in middle of back, shading to nearly pure buff on sides; feet and underparts white; tail hair-brown above, whitish below; ears drab, usually with a tuft of ochraceous-buff hairs at base. Unworn summer pelage: Similar to the fresh winter pelage, but colors less strongly contrasted and black variations of upper parts much reduced. Worn spring and summer pelage: General tone browner and colors less contrasted 


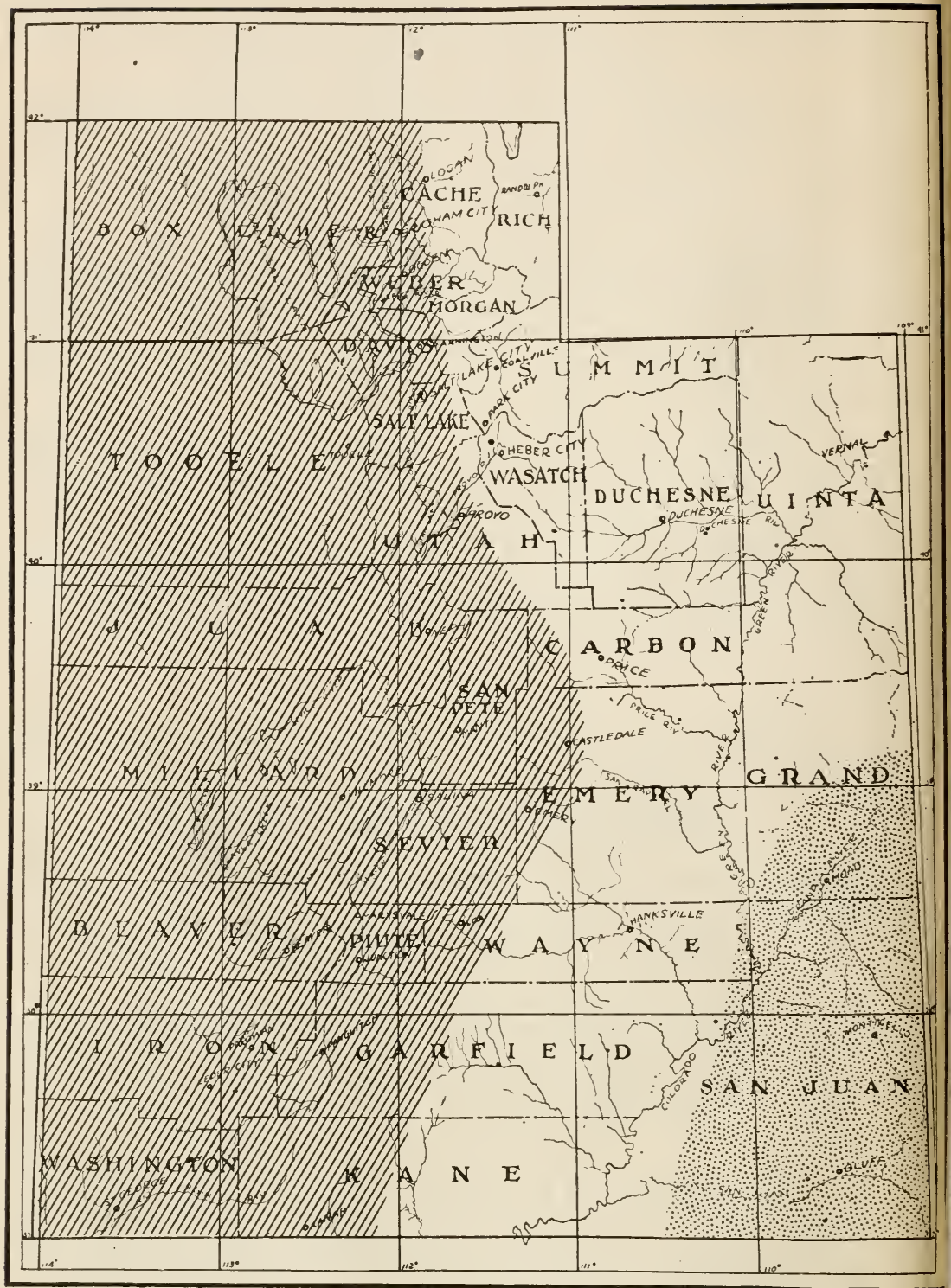

Map No. 13.-(Lined area) Range of Desert Harvest Mouse (REITHRODON. TOMYS MEGALOTIS MEGALOTIS Baird) in Utah. (Dotted area) Range of Aztec Harvest Mouse (REITHRODONTOMYS MEGALOTIS AZTECUS Allen). Based on map of A. H. Howell. 
than in the winter pelage, the buff on sides less pronounced and often lacking. (Howell.)

\section{Distribution-The west half of Utah.}

Habits-The food of the harvest mouse consists mostly of seeds, grain, green vegetation, and some fruit. Mr. C. W. Seegmiller, of St. George, Utah, states that he has known the harvest mice to do some damage by climbing grain stalks and cutting off the heads. He has found their nests built several feet from the ground in close-growing clusters of grain stalks. (Howell.)

\section{AZTEC HARVEST MOUSE}

\section{REITHRODONTOMYS MEGALOTIS AZTECUS (Allen)}

Reithrodontomys aztecus Allen, Bull. Am. Mus. Nat. Hist. V. 1893, p. 79 .

Description-Characters-Similar to megalotis but with larger ears and skull. Color-Not appreciably different from that of megalotis; ears sometimes with irregular dusky blotches. (Howell.)

Distribution-This species ranges, throughout northern New Mexico, northeastern Arizona, southeastern Utah and western Colorado, north as far as Grand Junction. Specimens have been taken from Bluff City and Nolan's ranch on the San Juan river.

Habits-The habits of this species are the same as those of megalotis.

The harvest mice are pre-eminently field mice. Practically all the known species live in more or less open, grassy situations and are partial to neglected fields, with grasses or sedges and to weedy and grassy borders of cultivated tracts. Some species, and perhaps all, construct substantial nests of grasses, often lined with soft materials and placed either on the ground or in vines, bushes, or low trees some distance above the ground. All the species live chiefly above ground, but burrows are also used. (Howell.) 


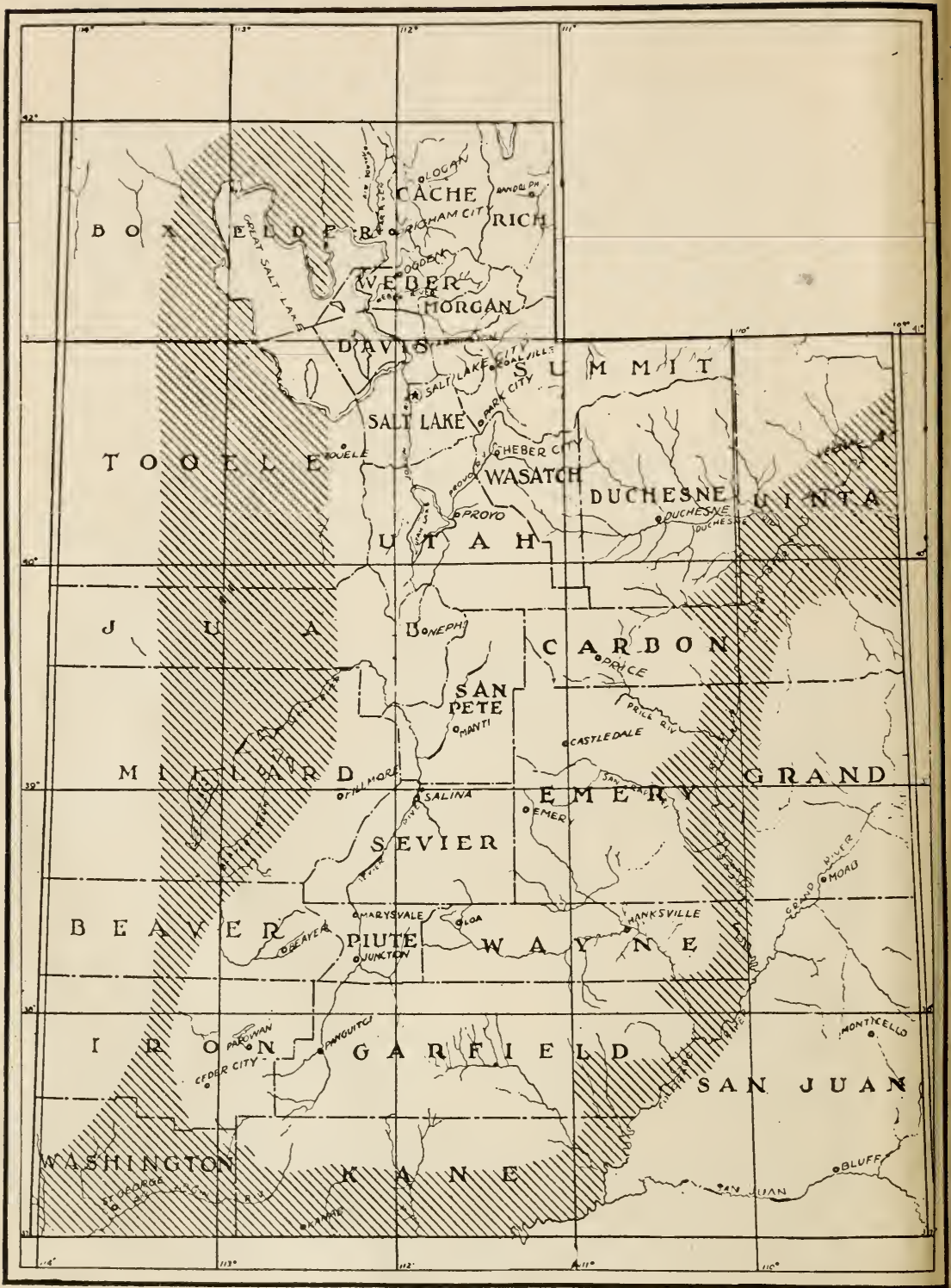

Map No. 14.-Distribution of Desert Wood Rat (NEOTOMA DESERTORUM Merriam) in Utah. Based on map of E. A. Goldman. 


\section{Subfamily NEOTOMINAE-Wood Rats.}

\section{DESERT WOOD RAT}

\section{NEOTOMA DESERTORUM (Merriam)}

Neotoma desertorum Merriam, Proc. Biol. Soc. Wash. IX, pp. 125-126, July 2, 1894. Type from Furnace Creek, Death Valley, Inyo County, Cal.; No. 25739/33139, male adult, U. S. Nat. Mus. (Biol. Sur. Collection); collected by T. S. Palmer, January 31, 1891.

Neotoma bella Bangs, Proc. New Eng. Zool. Club, I, pp. 66-67, July 31,1899 . Type from Palm Springs, Riverside County, Cal.; No. 5308, male adult, collection of E. A. and O. Bangs; collected by E. C. Thurber, April 12, 1896.

Neotoma nevadensis Taylor, Univ. Cal. Pub. Zool. V, pp. 289296, pls. 27-29, February 12, 1910. Type from Virgin Valley, Humboldt County, Nevada; No. 8282, female, Univ. of Cal. Mus. of Vertebrate Zoology; collected by Annie M. Alexander, May 17, 1909.

Description-Fresh pelage: Upper parts pale pinkish buffy, purest on cheeks and sides, becoming creamy buff on middle of face, moderately darkened dorsally by blackish hairs; feet and underparts white, the belly in some specimens more or less suffused with pinkish buff; sides of neck pinkish buff, this color sometimes spreading across throat; tail varying from grayish brown to blackish above, white below. (Goldman.)

Distribution-Desert regions in California, Nevada, eastern Oregon, northern and western Utah, ranging along the Colorado River and Green River systems to the Colorado line. Specimens have been taken in Utah from Fort Cameron, Henry mountain, Kanab, Kelton, Little Pine valley, Loa, Moccasin spring, Promontory, St. George and Santa Clara.

Habits-Members of this genus live usually in rocky or mountainous regions where cliffs, caves, crevices or overhanging shelves afford protection; but some species prefer plains or bushy hillsides where they build large conical nests of sticks and rubbish. The nests, which often appear even besides cliffs, have from half to a dozen entrances, some above, some below the surface of the ground. The runways radiate to the adjoining vegetation. All wood rats are expert climbers, some even building nests among the branches of trees.

Wood rats are chiefly nocturnal in habits, their food consisting of grass, fruit, bulbs, bark, seeds, nuts, and fungi. Their enemies include owls, hawks, snakes, wild cats, coyotes, foxes, and probably weasels. They sometimes girdle shrubs, injure growing crops and steal stored grain. 


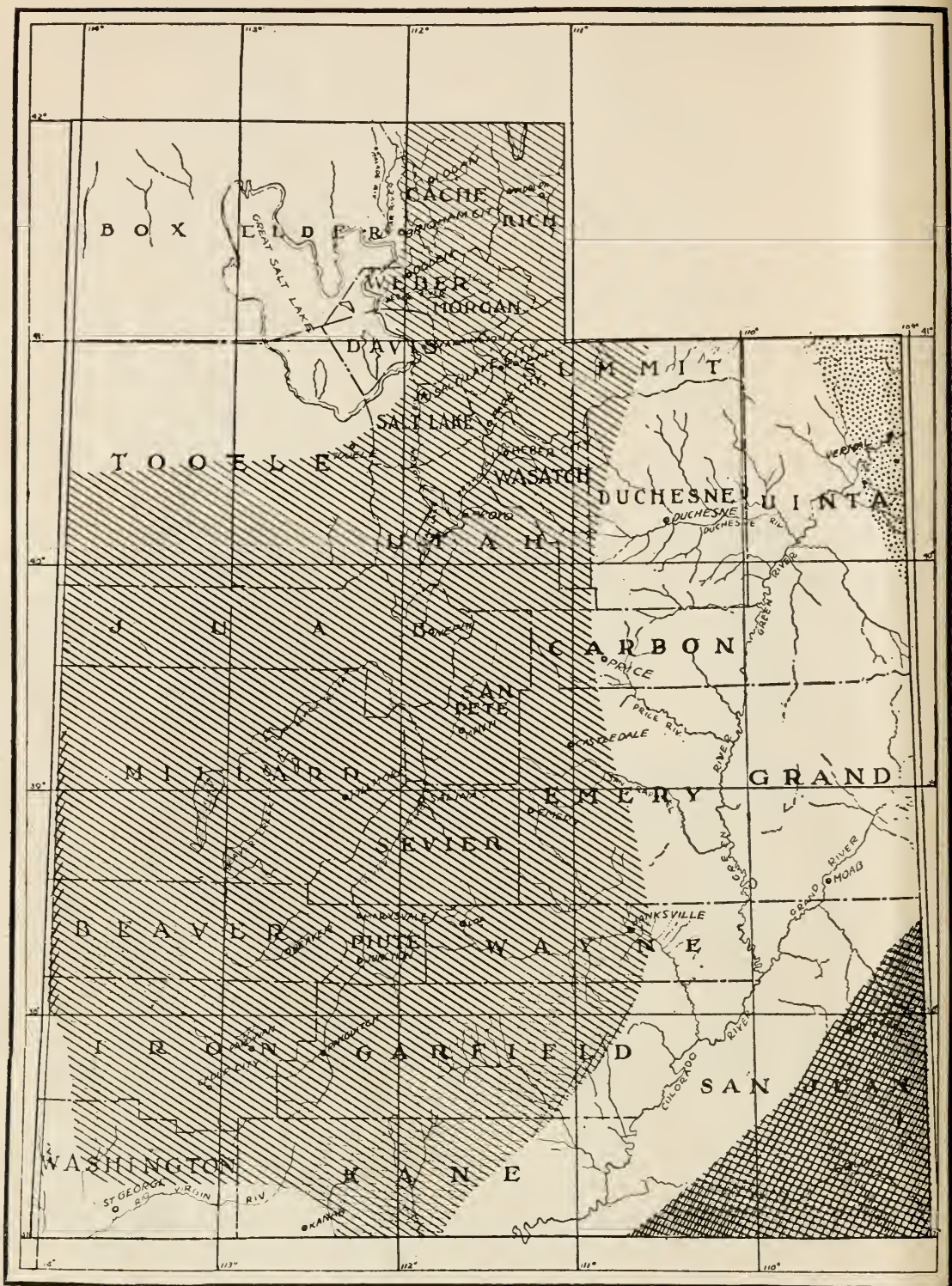

Map No. 15.-(Lined area) Distribution of Gray Bushy-tailed Wood Rat (NEOTOMA CINEREA Ord) in Utah. (Dotted area) Range of Cinnamon Bushy-tailed Wood Rat (NEOTOMA CINEREA OROLESTES Merriam) in Utah.) (Double line area) Range of Arizona Wood Rat (NEOTOMA CINEREA ARIZONAE Merriam) in Utah. Based on maps of E. A. Goldman. 


\section{GRAY BUSHY-TAILED WOOD RAT}

\section{NEOTOMA CINEREA (Ord)}

Mus cinereus Ord, Guthrie's Geog., 2d Amer. ed., II, p. 292, 1815. Type from Great Falls, Cascade County, Mont.: "Based on the ash-colored rat of Rocky Mountains of Lewis and Clark."

Neotoma cinerea Baird, Mamm. North Amer., p. 499, 1857.

Teonoma cinerea acraia Elliot, Pub. Field Columb. Mus. Zool. Ser., III, pp. 247-248, December, 1903. Type from Hot Springs, Long Canyon, Mount Whitney, Inyo County, Cal.; No. 12850, female, Field Mus. of Nat. Hist., collected by Edmund Heller, July 31, 1903.

Description-Fresh pelage: Upper parts grayish buff, in some specimens varying to ochraceous buff, palest on face, the back much darkened by admixture of dusky hairs ; lower surface, including upper lip, white, the hairs along sides of belly pale plumbeous basally; forefeet white, this color insensibly passing over fore limbs into general color of upper parts; hind feet white; color of hind legs reaching a short distance over tarsus; ears covered with brownish and grayish hairs, and faintly edged with whitish; tail above brownish gray, below white, usually crossed basally by a pale buffy band. (Goldman.)

Distribution-Mountainous region of Montana, Idaho, western Wyoming, Utah, northern Arizona, central Nevada and central California. Specimens have been taken in Utah from Beaver mountain, Blacksmith Fork, Cache county, Fish Lake plateau, Henry mountain, Ogden, Parowan and Provo.

Habits_The presence of woodrats is generally indicated by accumulations of odds and ends filling the crevices of rocks about their retreats, or piled about the entrances to their burrows, such accumulations including small sticks, pieces of bark, leaves, cactus, burrs, bones, stones, and any other small objects which may be found in the vicinity. In northern localities they gather stores of pinyon or other nuts, potatoes, corn, and other non-perishable food, concealing these supplies in cavities in the nests either above or below the ground. They eat many kinds of fruits, seeds, leaves, and other parts of plants, sometimes including bark of shrubs or small trees and even cactus pads. They are mainly nocturnal and appear to be extremely active throughout the night. 


\section{ARIZONA WOOD RAT}

\section{NEOTOMA CINERA ARIZONAE (Merriam)}

Neotoma arizonae Merriam, Proc. Biol. Soc. Wash., VIII, pp. 110-111, July 31, 1893. Type from Keam Canyon, Apache County, Arizona; female adult, Merriam Collection; collected by J. Sullivan, May 21, 1888.

Description-Fresh pelage: Upper parts varying from pale to bright ochraceous buff, purest along cheeks and sides, thinly overlaid with dusky; feet and under parts white; tail grayish brown above, white below. (Goldman.)

Distribution-Northeastern Arizona, southeastern Utah, southwestern Colorado and northwestern New Mexico. Specimens have been taken at Bluff City, Utah. It is said that the pale coloration of arizonae is the result of its desert environment.

\section{CINNAMON BUSHY-TAILED WOOD RAT}

\section{NEOTOMA CINEREA OROLESTES (Merriam)}

Neotoma orolestes Merriam, Proc. Biol. Soc. Wash., IX, p. 128, July 2, 1894. Type from Saguache Valley, 20 miles west of Saguache, Saguache County, Colo.; collected by J. Alden Loring, August 13, 1892.

Neotoma garangeri Allen, Bull. Amer. Mus. Nat. Hist. VI, pp. 325-326, November 7, 1894. Type from Custer, South Dakota.

Neotoma cinnamonea Allen, Bull. Amer. Mus. Nat. Hist. VII, pp. 331-332, November 8, 1895.

Description-Color-Fresh pelage (October): Upper parts ochraceous buff, purest along sides, darkened over back by blackish hairs; head slightly paler; under parts and feet dull white, the hairs over pectoral and inguinal regions white to roots ; tail above on proximal third grayish buff, becoming brownish buff on distal two-thirds; below white with a more or less distinct pale buffy band across base. Young (about half grown) : Darker than in N. cinerea. (Goldman.)

Distribution-This species ranges mostly throughout Wyoming and the greater part of Colorado, touching Utah only in the extreme northeast, close to the Wyoming-Colorado line. 
Subfamily MICROTINAE-Voles.

\section{PEALE VOLE}

\section{MICROTUS MONTANUS (Peale)}

Arvicola montanus Peale, U. S. Exploring Exp'd. Mammalogy, 44, 1848.

Arvicola longirostris Baird, Mamm. N. Amer. 530-531, 1857. (From upper Pitt River, California.)

Description-Summer pelage: Upper parts bister or ashy mixed with blackish; belly washed with soiled whitish, giving a smoky gray or dusky color; feet plumbeous; tail indistinctly bicolor, blackish above, plumbeous below; lips usually showing a trace of whitish. (Bailey.)

Distribution-Northern Utah, Nevada, northeastern California and eastern Oregon. Specimens have been taken at Ogden, Salt Lake City, Provo, Fairfield and Manti.

Habits-The voles are easily discovered by their tunnels and runways through the meadow grass. They build bulky nests beneath the surface. Their food consists of grass, bark, seeds, grain and some flesh; and they do severe damage throughout their range.

Voles seem to have no definite breeding season. Four to eight young are usually produced at a birth, and in Utah young may be found in the nests at all times of the year. They form the principal food of nearly all hawks and some owls, while weasels, minks, foxes, coyotes, cats, badgers, skunks, and many other animals as well as some snakes, feed on them. (Bailey.)

Among the snakes found in northern Utah, that feed on these voles may be mentioned the following: the Desert gopher snake (Pituophis catenifer deserticola), the redbarred or Pacific garter snake (Thamnophis sirtalis parietalis), the gray or wandering garter snake (Thamnophis ordinoides elegans) and the Pacific rattlesnake (Crotalus oregonus).

\section{UTAH MEADOW VOLE}

\section{MICROTUS MONTANUS RIVULARIS (Bailey)}

Microtus nevadensis rivularis Bailey, Biol. Soc. Wash., XII, 1898, p. 87.

Microtus montanus rivularis Elliot, Syn. N. Am. Mamm., F. C. M. Pub. II, 1901, p. 184 . Zool. Ser.

Description-Winter pelage: Upper parts dull bister, darkened with blackish-tipped hairs; sides scarcely paler; 
belly washed with white; feet dull grayish; tail bicolor, blackish above, grayish below. Young: Darker than adult, but not black backed as in nevadensis. (Bailey.)

Distribution-The type locality of this species is St. George, Utah, where it inhabits the tule marshes along the banks of the Virgin river. Its true extent is not known.

\section{SAWATCH VOLE}

\section{MICROTUS PENNSYLVANICUS MODESTUS (Baird)}

Arvicola modesta Baird, Mamm. N. Am., 535-536, 1857.

Arvicola insperatus Allen, Bul. Am. Mus. Nat. Hist. 347, 1894 (Custer, S. Dak.).

Description-Summer pelage: Upper parts dull ochraceous, darkened with black-tipped hairs; belly washed with soiled whitish, smoky gray or pale cinnamon; feet plumbeous; tail indistinctly bicolor, blackish above, dull grayish below. Winter pelage: Much darkened above by long black hairs, especially early in the season, later becoming paler than in summer as the under-fur grows longer; belly heavily washed with creamy white; feet paler; tail more sharply bicolor. Young: Slightly less blackish than in pennsylvanicus. (Bailey.)

Distribution-Mountainous region from New Mexico to British Columbia. Specimens have been taken at Ogden and Salt Lake City, Utah.

Habits-Cary found these meadow mice feeding extensively upon the blossoms and leaves of the false Solomon's Seal (Vagnera stellata) and fragments of the blossoms of a species of Senecio.

\section{DWARF VOLE}

\section{MICROTUS NANUS (Merriam)}

Arvicola nanus Merriam, N. A. F. No. 5, 62-63, pl. II, figs. 5 and 6 , July 30,1891 .

Description-Summer pelage: Upper parts uniformly grizzled gray mixed with sepia and blackish hairs; belly washed with white; feet grayish or plumbeous; tail bicolor, 
dusky gray above, whitish below. (Winter pelage unknown). Young: Similar to adult, but slightly duller throughout. (Bailey.)

Distribution-Rocky Mountain and outlying ranges from central Idaho southward to central Nevada, and southern Colorado, in Canadian zone. Specimens have been taken from the Uinta mountains.

Habits-This species inhabits the boreal zones, being seen far above timberline on some of the mountain ranges. It prefers dry, grassy parks on the higher mountain slopes.

\section{CANTANKEROUS VOLE}

\section{MICROTUS MORDAX (Merriam)}

Arvicola (Mynomes) mordax Merriam, N. A. F. No. 5, 61, July $30,1891$.

Microtus vellerosus Allen, Bul. Am. Mus. Nat. Hist. XII, 7, March, 1899. (Liard River, Northwest Territory).

Microtus cautus Allen, Bul. Am. Mus. Nat. Hist. XII, 7, March, 1899. (Hell Gate, Liard River, Northwest Territory.)

Description-Summer pelage: Back grayish bister; sides olive gray ; belly washed with whitish; nose dusky ; feet plumbeous; tail dimly bicolor, dusky above, soiled whitish below. Winter pelage: Lighter colored than in summer; dorsal stripe of yellowish bister more sharply contrasted with the deeper gray of sides and face; belly heavily washed with pure white; tail sharply bicolor ; feet whitish. Young: Darker, less sharply marked than the adults; feet and tail dusky. (Bailey.)

Distribution-Rocky mountains and outlying ranges from latitude 60 degrees to northern New Mexico, and south in the Cascades and Sierra Nevada as far as Kaweah and Kern rivers, California. Specimens have been taken at Laketown, Park City, and Barclay.

Habits-This species is abundant throughout the Canadian and Hudsonian zones of the mountains, and follows down cold streams in places through the Transition zones. It is fond of forests and of cool, damp situations where the vegetation is rank. (Cary.) 


\section{BIG-FOOTED VOLE}

\section{MICROTUS RICHARDSONI MACROPUS (Merriam)}

Arvicola macropus Merriam, N. A. F. No. 5, 59-60, 1891.

Description-Summer pelage: Upper parts dark sepia, lined with long, black hairs; slightly paler on sides; belly washed with silvery white; feet dusky gray, tail distinctly bicolor throughout its length, sooty above, whitish below. Winter pelage (imperfect in October and May specimens.) Lighter, clearer gray above, black hairs less conspicuous, more heavily washed with white below. Young: Like adult or slightly darker, with long, woolly fur and dusky feet and tail; during one stage of pelage with entirely dusky belly. (Bailey.)

Distribution-Boreal zone of the Rocky mountains from the Wasatch north to Canada, and most of the intermediate ranges. Specimens have been taken from Park City.

\section{PIGMY VOLE}

\section{MICROTUS PAUPERRIMUS (Cooper)}

Arvicola pauperrima Cooper, Am. Nat. II, 535-536, Dec. 1868.

Description-Summer pelage: Upper parts uniform buffy gray, slightly darkened with dusky-tipped hairs; ears and nose strongly tinged with buff; belly pale buffy; tail darkened above by a dusky line, buffy below; feet like belly. Young: Less buffy and slightly more dusky than adult. (Bailey.)

Distribution-Eastern Washington and Oregon, central Idaho, and the north slope of the Uinta mountains, Utah, in Transition zone. All of the specimens thus far taken in Utah are from the Uinta mountains.

\section{ROCKY MOUNTAIN MUSKRAT}

\section{FIBER ZIBETHICUS OSOYOOSENSIS (Lord)}

Fiber osoyoosensis Lord, Proc. Zool. Soc. London, 1863, I, 97, 1863.

Fiber zibethicus osoyoosensis Hollister, Proc. Biol. Soc. Wash. XXIII, I, 1910.

Description-Fresh pelage: Upper parts varying from uniform glossy mummy brown to black; slightly darker than 
in spatulatus; sides russet; under parts usually heavily colored with cinnamon and dark russet or brown hairs; throat and ventral region lighter; hips black. Worn pelage: Upper parts dull sooty brown, sides and under parts paler, usually with few rusty overlying hairs. Young: Seal brown, paler beneath. (Hollister.)

Distribution-Southern British Columbia, Washington, Idaho, and western Montana, south in the mountains to northern New Mexico. Specimens have been taken at Utah Lake, Ogden and Laketown. This species is found quite generally throughout northeastern Utah, being the common muskrat of that vicinity. S. B. Locke reports that muskrats are common in the LaSal mountains district.

Habits-Where the brook gurgles softly into the reedcovered pond and surrounding willows protect from intrusion ashore, the muskrat builds its home, depending summer and winter upon the swampy waters for food, protection and shelter. Even the entrance to the den is below the water line, though, shortly, the passage ascends to a snug compartment with an air hole leading up through accumulated rushes and twigs.

Anatomically the muskrat is merely an immense meadow mouse with a naked tail flattened on the sides.

A muskrat usually lives and dies in a single marshy pond unless perchance the water is dried away; and seldom, indeed, does it go over a hundred yards from its hole.

More sociable than the rabbit, less so than the beaver, muskrats usually join efforts to build a rat-house or lodge, and at the approach of danger, the discoverer alarms its companions with a splash of considerable loudness. If imperiled they frequently join forces, too, in fighting a common enemy.

About the middle of April the species pair, much loud snarling, squealing, and splashing being heard in the nighttime, some of the combatants' tails being either mangled or chewed off. In thirty days from four to nine naked, blind, helpless, young are born, which are suckled until three weeks or a month old. As many as three litters are raised in a year; and from the manner in which the male assists in nest building the species is thought to be monogamous.

In July the family begins to build the winter home. Selecting a reed-surrounded strip of shallow water, they drag mud, sticks and vegetation together until the pile is three or four feet high, capped with rushes. As the roof caves in, it is eaten away until finally a self-supporting dome is formed ready to protect the occupants from the chill blasts of winter. 


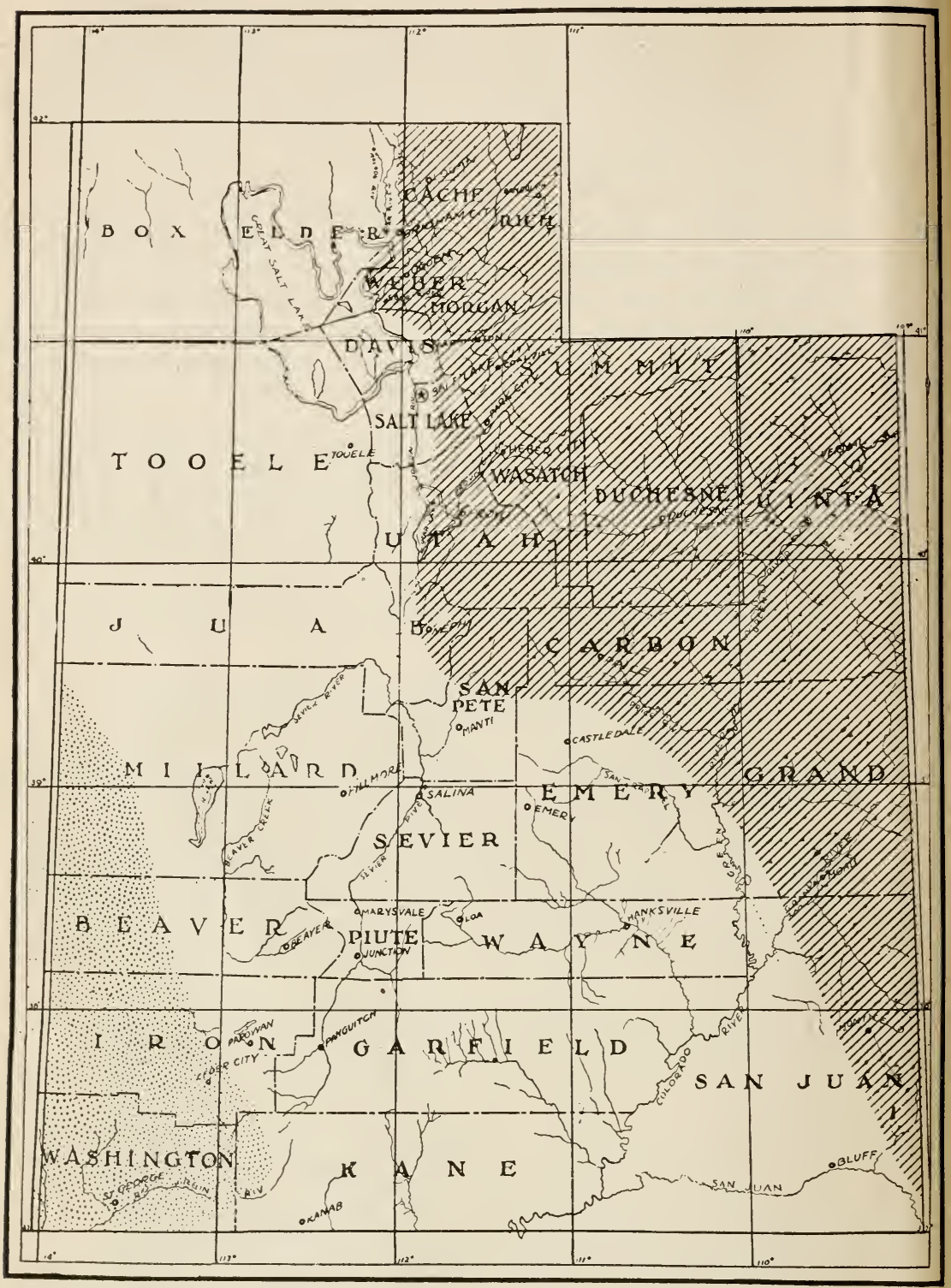

Map No. 16.- (Dotted area) Range of Nevada Muskrat (EIBER ZIBETHICUS MERGENS Hollister) in Utah. (Lined area) Range of Rocky Mountain Muskrat (FIBER ZIBETHICUS OSOYOOSENSIS Lord) in Utah. From map of N. Hollister. 
About this home the muskrats place at varying distances, little rafts of rushes, which serve as landing places in summer and breathing holes in winter; for, as the rat ventures afar under the ice in search of food, he must have places where he can rest and eat a bit before exploring for another piece of weed.

Vegetable matter, such as the bleached ends of long reeds, lilies, stalks and the roots of flags, constitute the greater portion of the muskrat's food though, at times, it eats clams, fish, insects, and even young birds. Quantities of green stuff are stored in their dens to be used as bedding as well as food.

Hawks, owls, weasels, otters, foxes, and many other visitants of the pond are the muskrat's enemies, but the most fearful of all is the mink, which deliberately goes into the poor rat's den to the farthest recess. The pursued rat's only hope is to dive, for the mink is only an ordinary swimmer.

Winter skins sell at 40 cents to $\$ 2.75$ each, according to size and quality; the price of fall skins ranges from 25 cents to $\$ 2.25$.

\section{Family GEOMYIDAE-Pouched Rats}

\section{NEVADA MUSKRAT \\ FIBER ZIBETHICUS MERGENS (Hollister)}

Fiber zibethicus mergens Hollister, Proc. Biol. Soc. Wash. XXIII, I, February 2d, 1910.

Description-Fresh pelage: Above, grayish brown; head and dorsal area blackish; cheeks, shoulders and sides rusty; under parts creamy white with central area pale cinnamon or russet; usual spot on chin blackish brown. Fall specimens, before the black hairs have come in, are sometimes quite rusty above. Worn pelage: Above, uniform pale yellowish brown, sides and under parts with little rusty. (Hollister.)

Distribution-Northern part of the Great Basin, southeastern Oregon, northeastern California, Nevada and western Utah. The Utah specimens thus far are from St. George.

Clinton Milne says: "Muskrats are numerous in the streams and swamps near St. George, and are on the increase. I do not think they do much damage. Many trap the muskrat and sell their pelts for from 25 to 35 cents." 


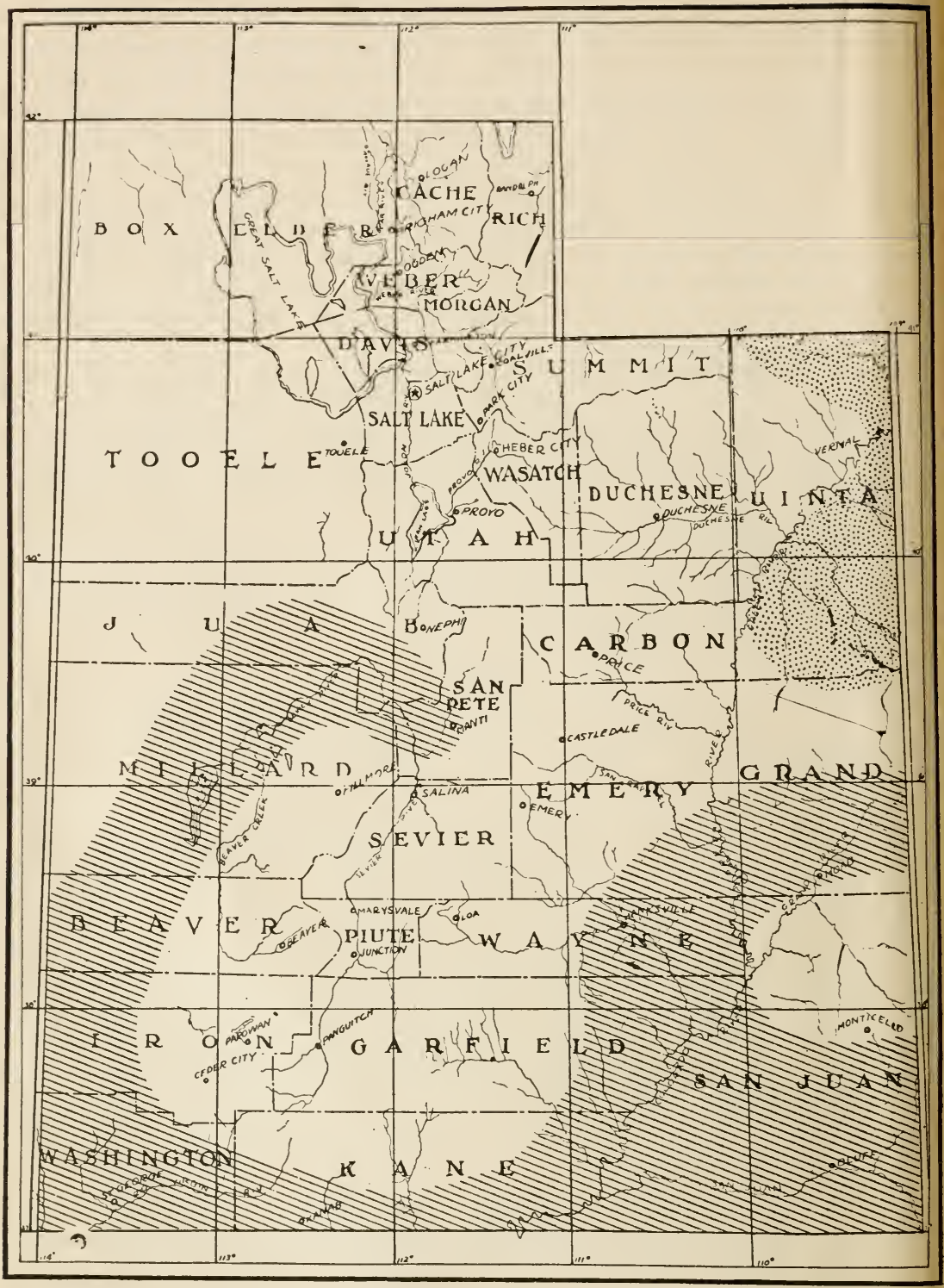

Map No. 17.-(Lined area) Range of Yellow Pocket Gopher (THOMOMYS PERPALLIDUS AUREUS Allen) in Utah. (Dotted area) Range of Swift Pocket Gopher (THOMOMYS OCIUS Merriam) in Utah. Based on map of Vernon Bailey. 


\section{GREEN RIVER POCKET GOPHER: SWIFT POCKET GOPHER}

\section{THOMOMYS OCIUS (Merriam)}

Thomomys calusius ocius Merriam, Proc. Biol. Soc. Wash. XIV, 114, July 19, 1901.

Description-Summer pelage: Upper parts light buffy gray, more strongly buffy or tinged with brownish on crown and back; sides clear gray; cheeks darker gray; ear patch blackish but small; under parts, feet, and tail soiled whitish or creamy. Winter pelage: Upper parts lighter buffy gray; nose and cheeks clearer gray; under parts whitish or creamy. (Bailey.)

Distribution-Green River Basin of southwestern Wyoming, northwestern Colorado and northeastern Utah. Specimens have been taken in Utah on the Uncompahgre Indian reservation.

This species prefers the sagebrush mesas along the Green River.

\section{UINTA POCKET GOPHER}

\section{THOMOMYS UINTA (Merriam)}

Thomomys uinta Merriam, Proc. Biol. Soc. Wash. XIV, 112, July 19, 1901.

Description-Summer pelage: Upper parts dull dark brown, with dusky nose and face and blackish ear and ear patch; under parts buffy or ochraceous, with occasionally a white patch on chin; feet and tip of tail usually whitish. Late fall and winter pelage: Duller and more grayish. Young, paler, more buffy than adults. (Bailey.)

Distribution-Western Wyoming, southeastern Idaho, and northern Utah. The Utah specimens have come from Kelton, Ogden, Park City, Parley's canyon and the Uinta mountains. (9,000-10,000 feet.)

Habits-This species lives in the same mountain districts and has quite the same environment as the Colorado Pocket Gopher. 


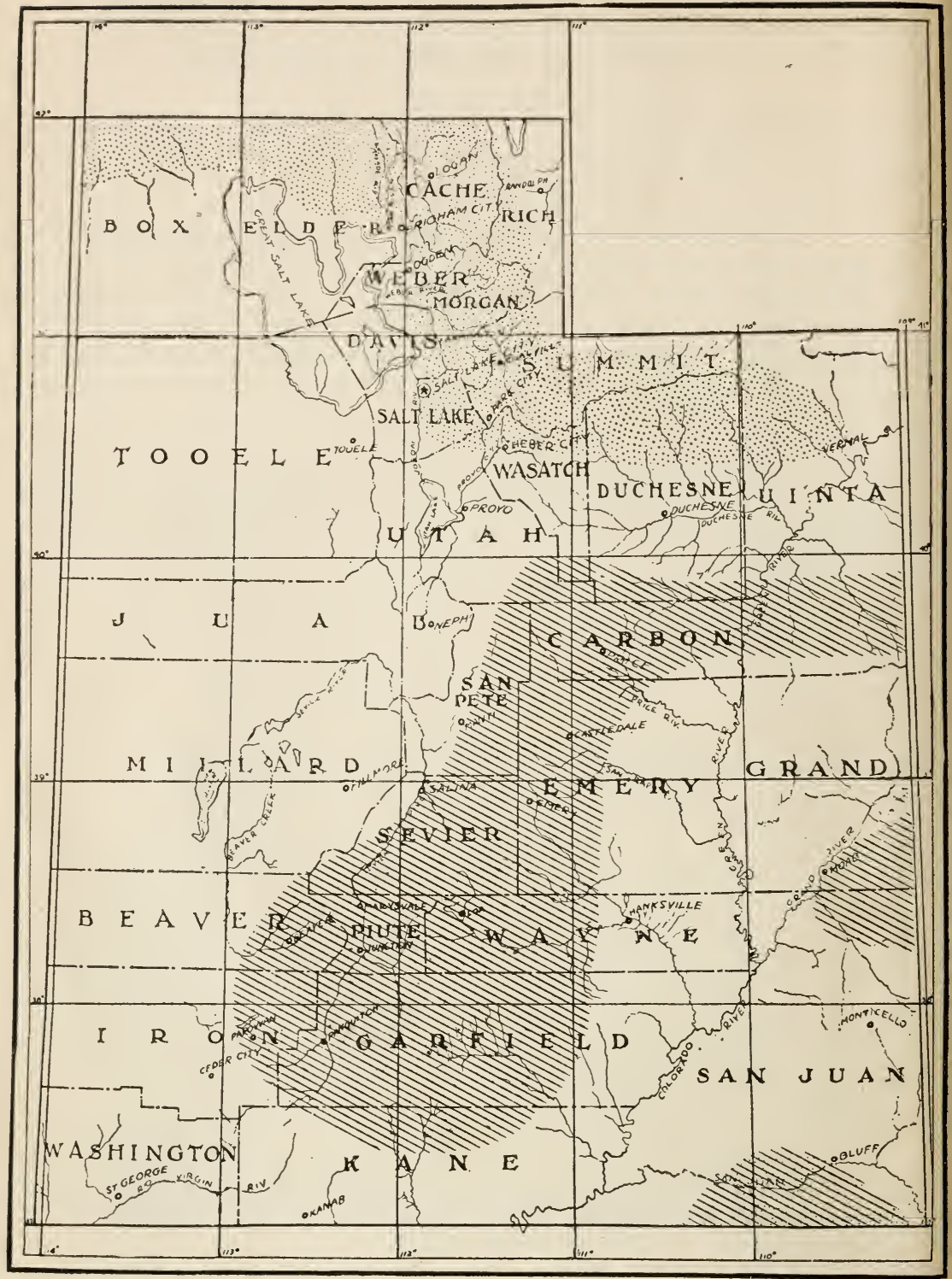

Map No. 18.-(Lined area) Distribution of Colorado Pocket Gopher (THOMOMYS FOSSOR Allen) in Utah. (Dotted area) Distribution of Uinta Pocket Gopher (THOMOMYS UINTA Merriam) in Utah. Based on maps of Vernon Bailey. 


\section{COLORADO POCKET GOPHER}

\section{THOMOMYS FOSSOR (Allen)}

Thomomys fossor Allen, Bul. Am. Mus. Nat. Hist. V, 51, April 28, 1893.

Description-Summer pelage: Upper parts dull dark brown with sometimes a rich chestnut tone; ear and postauricular patch black; nose and face dusky; under parts buffy or ochraceous; part of feet and tip of tail usually whitish; chin usually, and spot on breast sometimes, white. Winter pelage: Duller, more grayish or drab. Young: In summer paler and more buffy than adults. (Bailey.)

Distribution-Mountains of western Colorado, extreme southern Wyoming, northern New Mexico, eastern and southern Utah, and northwestern Arizona. Specimens have been taken at Beaver mountain, Buckskin Valley, Fish Lake, LaSal Mountains, Panguitch Lake and Parowan Mountains.

Habits-On the higher open mountain slopes, particularly above timberline, one often sees peculiar long serpentine ridges of earth, sometimes dry and hard packed, but more often partially disintegrated through the action of moisture. These are formed by gophers during the winter when snow covers the ground to a considerable depth. The loose earth thrown out is packed into the ramifying tunnels which the animal has made through the snow on the surface of the ground. (Cary.)

\section{YELLOW POCKET GOPHER}

\section{THOMOMYS PERPALLIDUS AUREUS (Allen)}

Thomomys aureus Allen, Bul. Am. Mus. Nat. Hist. V, 49, April 28, 1893.

Description-Winter pelage: Upper parts beautiful orange-buff varying to paler and darker shades and sometimes with a wash of dusky along the back; ear patch and nose blackish in the darker and slightly dusky in the lighter individuals; under parts, feet and tail creamy white. Summer pelage: Slightly darker. Young: more grayish. (Bailey.)

Distribution-Desert regions of southern Nevada, southern Utah, western Colorado, central and northwestern 
New Mexico, and northern and western Arizona. Utah specimens have been taken at Bluff City, Hanksville, Hebron, Henry Mountain, Kanab, Manti, Mountain Meadows, Pine Valley, St. George, Pine Valley Mountains and Santa Clara.

Family HETEROMYIDAE-Kangaroo Rats, Pocket Mice Subfamily DIPODOMYINAE

\section{UTAH KANGAROO RAT}

\section{PERODIPUS MONTANUS UTAHENSIS (Merriam)}

Perodipus montanus utahensis Merriam, Proc. Bio. Soc. Wash. XVII, 1904, p. 143.

Description-Similar to P. montanus; hind foot smaller; upper parts less fulvous; ears darker, the anterior fold dusky except at extreme tip; ventral tail stripe continuous to tip of pencil. (Elliot.)

Distribution-The type locality of this form is Ogden, Utah; and the extent of its range is unknown.

Habits-Kangaroo rats are neither kangaroos or rats, but near relatives of the pocket mice, which share their desert haunts. They are characterized by a kangaroo-like form, including small fore legs and feet, long hind legs and feet for jumping, and a tail longer than the body to serve as a balance. In addition they have large prominent eyes and are provided with skin pouches on each side of the mouth for use in carrying food. Being desert animals they live like pocket mice, without drinking, obtaining the necessary water through their digestive processes. They are most numerous in sandy areas where the earth is sometimes so riddled by their burrows that horseback riding over them is dangerous. Kangaroo rats are nocturnal and always live in burrows dug by themselves. They do not hibernate but lay up stores of food for temporary purposes. Their food consists of seeds, leaves of several plants and young plants just sprouting from the ground. (Nelson.) 


\section{LONG-FOOTED KANGAROO RAT: MOKI KANGAROO RAT}

\section{PERODIPUS LONGIPES (Merriam)}

Dipodops longipes Merriam, N. A. F. No. 3, 1890, p. 72.

Perodipus longipes Elliot, Sys. N. Am. Mamm. F. C. M. Pub.. II, 1901, p. 239. Zool. Ser.

Description-Color: Above, uniform ochraceous buff, finely lined with black-tipped hairs, the latter being most noticeable on the rump; a large, pure white spot over each eye and another behind each ear, cheeks between whiskers and ears, mostly white, slightly mixed with ochraceous. Under parts pure white to base of hairs, including fore legs and feet, band across thighs and hind feet (except soles, which are dusky). Upper tail stripe dusky, continuous to end of tail, but paler on the crested penicillate portion, where it involves the terminal half of each hair only; under tail stripe very narrow posteriorly and indistinctly continuous with the dark tip of the pencil; lateral white stripes broad and distinct from basal white ring to white basal portion of pencil. (Merriam.)

Distribution-Utah, Wyoming, Nebraska, New Mexico and Arizona.

Habits-The Moki kangaroo rat is a creature of the sandy desert areas of the southwest and is normally restricted to the lowest and warmest parts of the upper Sonoran zone. (Cary.)

\section{YAVAPAI POCKET MOUSE}

\section{PEROGNATHUS FLAVUS BIMACULATUS (Merriam)}

Perognathus bimaculatus Merriam, N. A. F. No. 1, 12, 1889; Allen, Bull. Am. Mus. Nat. Hist. N. Y. VII, 216, 1895.

Perognathus apache Allen, ibid. V, 71, 1893 (part).

Description-Color: As in flavus, but with a greater abundance of black-tipped hairs on dorsum; under parts white with occasional traces of buff; lateral line quite distinct; ears clear buff outside, blackish inside.

Distribution-Southeastern Utah and central and northeastern Arizona. The Utah specimens have come from Noland's ranch on the San Juan River. 


\section{APACHE POCKET MOUSE}

\section{PEROGNATHUS APACHE (Merriam)}

Perognathus apache Merriam, N. A. F. No. 1, 14, 1889; ibid., No. 3, 73, 1890; Allen, Bull. Am. Mus. Nat. Hist. N. Y. V, 71, 1893, (part) ibid, VII, 216, 1895.

Perognathus flavus subsp. Merriam, N. A. F. No. 3, 73, 1890.

Description-Color: Above rich buff, with light admixture of black, effecting a suspicion of olivaceous; lateral line moderately well defined; below, pure white, ears buff, very faintly dusky within, a white spot on inflexed part and on inferior margin; tail white below, buff above with traces of dusky toward tip. In the early spring "left-over" pelage the color is a beautiful clear buff with very few dusky-tipped hairs.

Distribution-Southern Utah, eastern Arizona and western New Mexico. The Utah specimens are from San Juan county.

\section{PANAMINT POCKET MOUSE}

\section{PEROGNATHUS PANAMINTINUS (Merriam)}

Perognathus longimembris panamintinus Merriam, Proc. Acad. Nat. Sci. Phila., September 27, 1894, 265.

Description-Color: Above, grayish buff, often with a pearly appearance caused by a pale buff ground color overlaid by dark-tipped hairs; lateral line pale buff, not sharply defined; subauricular spot small and inconspicuous; forelegs buffy or white; under parts white; tail, above, dusky, strongly so distally, below buff or whitish. (Osgood.)

Distribution-Panamint mountains, California, and eastward through southern Nevada to St. George, Utah. The Utah specimens are all from Washington county.

\section{NEVADA POCKET MOUSE}

\section{PEROGNATHUS NEVADENSIS (Merriam)}

Perognathus nevadensis Merriam, Proc. Acad. Nat. Sci. Phila., September 27, 1894, 264.

Description-Color: Much as in panamintinus, but darker, and with belly colored like sides. 
Distribution-Central Nevada, north to southern Oregon and northern Utah. The Utah specimens are from Kelton at the north end of Great Salt Lake.

\section{GREAT BASIN POCKET MOUSE}

\section{PEROGNATHUS PARVUS OLIVACEUS (Merriam)}

Perognathus olivaceus Merriam, N. A. F. No. 1, 15, 1889; ibid, No. 5, 71, 1891; Elliot, Field Columbian Mus. Zool. Ser. No. 10, 211, 1898.

Perognathus olivaceus amoenus Merriam, N. A. F. No. 1, 16, 1889.

Description-Color: Similar to the buff phase of $\mathbf{P}$. parvus, but with clearer, softer colors; above, bright cinnamon buff finely mixed with black; lateral line distinct; subauricular spot conspicuous; hairs of belly pure white or with plumbeous bases and buff tips; inner side of foreleg white or buff. Late fall pelage paler. (Osgood.)

Distribution-The type locality of this species is Kelton, Utah, though the range includes the upper Sonoran zone throughout the Great Basin from northern Utah and southern Idaho southwest to Owens valley, California, and west to southern Oregon and northeastern California. Specimens have been taken in Utah from Blacksmith Fork, Cache county, Kelton, Laketown, Nephi, Ogden, Otter Creek and Salt Lake City.

Habits-The habits of pocket mice, as of most other small mammals, are not very well known. Most species are strictly nocturnal and very shy, and many of them are difficult to trap. They live in small burrows from the entrances of which they throw out miniature mounds of earth like those of the pocket gopher. These burrows usually have two or more entrances, which often open under small bushes, and are closed with earth during the day. The food consists of seeds, which are carried in the cheek pouches and stored in chambers in the burrows. No species is known to hibernate. (Osgood.) 


\section{LONG-TAILED POCKET MOUSE}

\section{PEROGNATHUS FORMOSUS (Merriam)}

Perognathus formosus Merriam, N. A. F. No. 1, 17, October 25, 1889.

Description-Color: Above, grizzled sepia; below white; sides not noticeably lighter than back; dark hairs generally extending down front leg to forearm; ears dusky black, tuft of bristly hairs at base mixed black and whitish; subauricular spot small, noticeable only in very high pelage; feet white; tail buff to pencil below, buff mixed with dusky above, intensifying toward pencil, which is brownish black. Worn pelage, drab instead of sepia. Young: Smoky gray above, white below. (Osgood.)

Distribution-Southwestern Utah, southern Nevada, and the adjoining portion of California in the lower Sonoran zone. The type locality of this species is St. George, Utah.

Family ERETHIZONTIDAE Subfamily ERETHIZONTINAE

\section{WESTERN PORCUPINE: YELLOW- HAIRED PORCUPINE}

\section{ERETHIZON EPIXANTHUM (Brandt)}

Erethizon epixanthus Brandt, Mem. Acad. Imp. Scien. St. Petersb., 6th Ser, 1835, p. 390, pls. 1, 9. Elliot, Syn. N. Am. Mamm., F. C. M. Pub. II, 1901, p. 265. Zool. Ser. Erethizon epixanthum Elliot, Mamm. Middle Amer. and W. Indies, F. C. M. Pub. IV, Pt. I, 1904, p. 397, figs. 76, LIV. Zool. Ser.

Description-The general appearance of the animal is black and somewhat greenish yellow, due to the long outer hairs, which project three inches beyond the quills and short hairs, and are black with an inch or more of the tips yellow. These long hairs are wanting on the rump. The quills are yellowish with blackish tips, and are found all over the sides and upper parts, including tail, but not on nose. Mingled with the quills are short black hairs. Sides of belly with yellow hairs, middle with black. The long 
black and yellow hairs are found on the legs and feet except the soles which are naked and black. Total length, 32; tail vert., 6.8; hind foot, 4.25. (Warren.)

Distribution-State of Sonora, Mexico, into New Mexico, eastward to Missouri, west to the Pacific and north to Alaska and the limit of trees. (Elliot.) Porcupines are quite common in all of the wooded districts of Utah. I have taken specimens in the very heart of Salt Lake City. (Brigham street and Tenth avenue and D street.) Brigham Spencer informs me that they are common in Garfield, Wayne, San Juan, Grand and Emery counties. Speaking of Washington county, Clinton Milne says that he has "seen where a few have eaten the bark and roots of pine tree shrubbery." S. B. Locke says that they are not very common in the LaSal mountains, where they appear usually above 8,000 feet.

Habits - The food of porcupines consist largely of the bark of coniferous trees, and the lodge-pole pine seems to be preferred to firs and spruces. Occasionally such large areas of bark are gnawed from a tree that it dies. (Cary.)

Probably no other animal of the world is capable of inflicting a wound so terrible, a death so painful and slow, as that which the stupid porcupine can perpetrate with a single swoop of its quill-covered tail. It cannot throw the deadly needles, however, as many people suppose; but so quickly does it lash its tail and so neatly are the spines barbed that once the enemy is struck the quills easily pierce the flesh and remain to work mortification of their own accord. The result is excruciating pain and a lingering death, as awful as inevitable. Most scientists agree that the fangs of a lion produce immediate insensibility attended with little pain; but weeks of torment and starvation may follow before the defense of the porcupine completes its direful vengeance. Man can extract the quills; but an animal can only suffer, hopelessly, desperately, until the end.

Slow and listless, the porcupine neither migrates nor hibernates, but lives contentedly its whole life through, often in one small wood of hemlocks, jackpines, or elms. Bachman says that one confined itself during an entire winter to a space of about two acres. It may feed or move about at any hour, but it really prefers the soft dimness of evening, morning or moonlight.

Not numerous anywhere, the porcupine, non-sociable, non-gregarious, is in fact one of the most solitary of animals. Food may attract a number at once; but the quest is a meal, not company. 
A porcupine grunts, sniffs, squeaks, whines, chatters, mews and even shrieks or cries like a child. One that I killed near the Ensign ward church building in Salt Lake City groaned exactly like an old man when it died.

The nest of the porcupine, with its very poor bed, may be found in a hollow tree or $\log$, a hole under a rock or under the roots of a tree, or in the deep crevice of a low, overhanging rocky ledge.

Little is known of the marriage relations of the porcupine. Mating takes place in September or October, and the father takes no interest in the offspring. The young, usually two in number, born early in May, are monstrous in size. According to Merriam they are "actually larger and relatively more than thirty times larger than the young of the black bear at birth."

Clumsy and slow on the ground, the porcupine is exceedingly sluggish in a tree, frequently pottering for days on a single branch, and closely resembling a magpie's nest all the while. On account of its hollow quills, it easily floats in the water and thus paddles great distances.

\section{Family OCHOTONIDAE}

\section{CINNAMON CHIEF HARE}

\section{OCHOTONA CINNAMOMEA (Allen)}

Ochotona cinnamomea Allen, Bull. Brookl. Inst. Arts and Scien. I, No. 5, 1905, p. 121.

Description-Color: Above pale cinnamon rufous, varried with black on dorsal region; sides dull cinnamon; top of head and nape gray tinged with buff; hairs tipped with black; under parts grayish washed with buff; ears blackish externally, narrowly edged with white; inside grayish dusky; fore feet above buffy gray, soles silvery gray; hind feet soles black. (Elliot.)

Distribution-The type locality of this species is Briggs meadow, Beaver range, Beaver county, Utah, at an altitude of 11,000 feet. The extent of its range is not known.

S. B. Locke says that they are found in the LaSal mountains at about 9,000 feet elevation.

Habits-The pika, little chief hare or cony, as it is variously named, is about the size and shape of a small 
guinea pig, with a short, blunt head, broad, rounded ears, short legs, practically no tail and a long, fluffy coat of fur. While most nearly related to the hares and rabbits they have entirely different habits. They live permanently along the high crests of the mountains, mainly above timber line, though sometimes in rock slides among the upper spruces, firs and pines. They live wholly within the shelter of rock slides and shelter of shattered rock masses. They are mainly diurnal in habits, and throughout the day may be heard giving their odd little barking or bleating notes, "eh-eh." Their young, usually three or four in number, are born during early summer and are out soon foraging for themselves. They are active all winter long, living then on the hay and varieties of small plants that they stored during the summer and autumn. (Nelson.)

\section{PIKA OR CHIEF HARE}

\section{OCHOTONA UINTA (Hollister)}

Ochotona uinta Hollister, Proc. Bio. Soc. Wash. XXV, p. 58, $1912 \mathrm{M}$.

Description-Color: Upper parts from head to tail uniform clay color, finely lined with darker brown; head darker than back; under parts cream buff; hands and feet yellow buff. Ears dark brown edged with buff and with tuft of buff colored hairs inside. The peculiar color of this new species at once distinguishes it from all other American pikas. The close color resemblance to Ochotona bedfordi of Asia is remarkable. Three specimens from the type locality, all in full pelage are at hand. An old, faded, specimen from the Wasatch mountains, Utah, is probably of the same form. (Hollister.)

Distribution-The type locality of this species is the Uinta mountains. I am informed by N. W. Reynolds that this pika is common at Brighton and in Little Cottonwood canyon, Salt Lake County, Utah. Mr. F. A. Wrathall has several skins in his possession, and he informs me that they appear everywhere in the Wasatch where there is slide rock.

Professor Marcus E. Jones informs me that the pika is found in all the sub-alpine and alpine regions of the Wasatch mountains from Mt. Timpanogas to the northern Utah line.

Habits-The habits of conies are most interesting. As far as my observation goes, they live entirely in slide rock, 
usually on steep slopes. . . . The hay stacks of these industrious little animals, comprising their winter food, are composed of many species of grasses and weeds, cut and gathered in summer, and allowed to dry among the rocks. Thistles are found in most of these stacks, and seem to be a favorite food. Well worn runways lead frum one stack to another and extend to neighboring rock slides. Conies are usually quite shy and would be seldom observed were it not for the odd, complaining notes which they utter continually when alarmed. (Cary.)

\section{PAROWAN PIKA}

\section{OCHOTONA SCHISTICEPS FUSCIPES (Howell)}

Ochotona schisticeps fuscipes Arthur H. Howell, Proc. Biol. Soc. Wash., Vol. 32, p. 110, May 20, 1919.

Description-Color of type in summer pelage: Upper parts mixed light pinkish cinnamon and fuscous-black (the blackish prevailing); tip of nose fuscous-black; sides of nose and face smoke gray, tinged with buff and washed with fuscous; back of head and nape washed with' pale neutral gray; ears fuscous black, margined with buffy white; sides pinkish cinnamon mixed with fuscous, becoming clear pinkish cinnamon along side of belly; hind feet soiled whitish washed with pale cinnamon buff, the soles fuscous; front feet cinnamon buff, the palms hair-brown; under parts grayish white, heavily washed with pinkish cinnamon. (Howell.) Mr. Howell states that it is similar to 0. cinnamomea, but larger with larger and relatively broader skull and more blackish coloration.

Distribution-The type specimen was taken by Wilfred H. Osgood on September 7, 1908, from Brian Head, Parowan mountains, Utah. The race is based on a series of five adults and one young, all from the same place. The limits of its range are at present unknown.

Habits-Nothing is known of its habits except that it is apparently more closely related to schisticeps of the northern high Sierra and to taylori of southern Oregon than to cinnamomea, its neighbor. 


\section{Family LEPORIDAE-Hares, Rabbits}

\section{WYOMING COTTONTAIL}

\section{SYLVILAGUS AUDUBONI BAILEYI (Merriam)}

Lepus baileyi Merriam, Proc. Biol. Soc. Wash. XI, p. 148, June $9,1897$.

Description-Color in fresh winter pelage: Upper parts of head and body nearly uniform pale cream buff, slightly darkened by thin overlying wash of black; sides of head and body a little paler or grayer than back; rump dull iron gray, forming a not strongly contrasted patch; top of tail like rump; outside of ears similar to top of head, but slightly darker and edged around tip with black; inside of ears dull grayish white becoming more buffy about borders; nape light rufous approaching ochraceous buff; front and outside of fore legs ochraceous buff varying in intensity, sometimes approaching dark buff, and shading into dark buff on tops of fore feet; back and sides of lower hind legs dark buff, sometimes shaded with brownish but rarely showing traces of the dark cinnamon or reddish shades characteristic of warreni; lower border of flanks scarcely more buffy than rest of sides; underside of neck dark buff, varying to deep pinkish or creamy buff. The young in immature pelage are darker and more buffy brownish gray on upper parts than the adults. The postjuvenal pelage is slightly darker and more grizzled gray than the adult, with darker brownish gray ears and more rusty legs. The young are often not very different from those of arizonae and minor. (Nelson.)

Distribution-Plains and valleys of eastern Montana, most of Wyoming, northeastern Utah, northwestern and eastern Colorado, western parts of North and South Dakota, Nebraska, and as far east as Trego county, Kansas. The Utah specimens are from the Uncompahgre Indian reservation.

Habits-Throughout its range the plains cottontail is pre-eminently an inhabitant of the semi-arid Upper Sonoran plains, where it lives in holes along the steep cut banks of dry arroyos, in the deserted burrows of prairie dogs and often in holes beneath sagebrush, atriples, or prickly pear (opuntia polyacantha) on the open plains. Its flesh is well flavored and tender. (Cary.) 


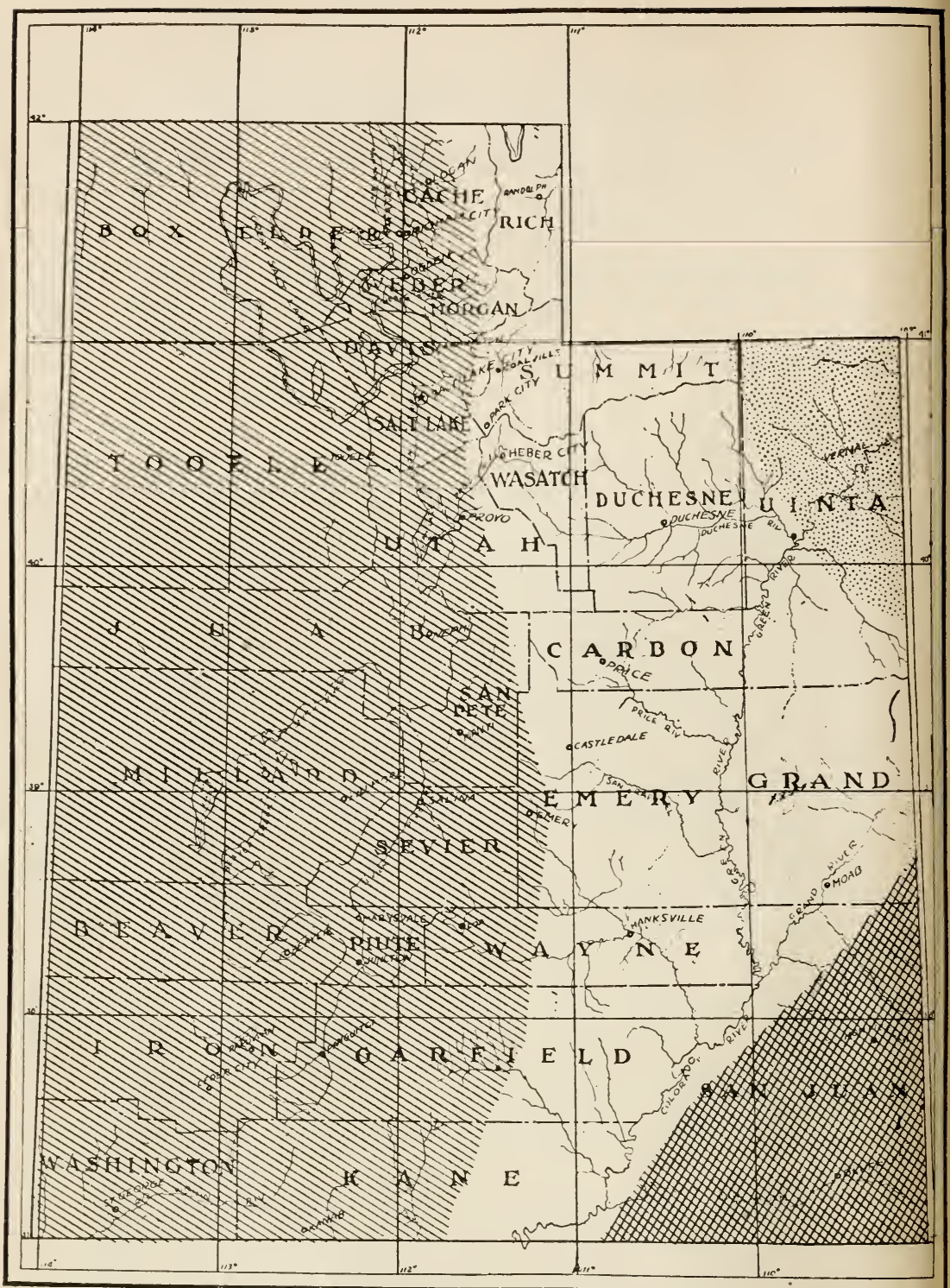

Map No. 19.-(Lined area) Range of Colorado Desert Jack Rabbit (LEPUS CALIFORNICUS DESERTICOLA Mearns) in Utah. (Dotted area) Range of Wyoming Cottontail (SYLVILAGUS AUDUBONI BAILEYI Merriam) in Utah. (Double line area) Range of Colorado Cottontail (SYLVILAGUS AUDUBONI WARRENI Nelson). Based on maps of E. W. Nelson. 


\section{COLORADO COTTONTAIL}

\section{SYLVILAGUS AUDUBONI WARRENI (Nelson)}

Sylvilagus auduboni warreni Nelson, Proc. Biol. Soc. Wash. XX, p. 83, July 22, 1907.

Description-Color in fresh winter pelage: Upper parts of head and body dark creamy buff strongly washed on back with black; sides of head and body grayer and washed with less black than back and shading into clear dull buff along lower border of flanks; outside of ears similar to back, or a little grayer; nape light rusty rufous; rump iron gray, forming a well-defined patch; top of tail like rumps front and outside of fore legs varying from dark rusty ochraceous buff to light rusty cinnamon rufous; tops of fore feet white, more or less shaded with buff; back and outside of hind legs cinnamon, varying to lighter more rusty cinnamon and to darker more cinnamon brown; tops of hind feet vary from white to pale buff; the rusty areas on fore and hind legs connected by buffy line along lower border of flanks; underside of neck varies from dull dark buff to dark buff tinged with fawn color; inguinal area more or less deeply buffy. (Nelson.)

Distribution-Southwestern Colorado, southeastern Utah, northwestern New Mexico, northeastern Arizona. Specimens have been taken at Canesville, Hanksville and Mount Ellen of the Henry mountains.

Habits-Ranchmen state that their numbers near Bluff City, Utah, are at times so great that nearly all the range grasses in the vicinity of canyons are eaten by them before the middle of June. (Cary.)

\section{BLACK HILLS COTTONTAIL}

\section{SYLVILAGUS NUTTALLI GRANGERI (Allen)}

Lepus sylvaticus grangeri Allen, Bull. Am. Mus. Nat. Hist. VII, pp. 264-265 (author's separates issued August 21, 1895).

Lepus 1 (aticinctus) perplicatus Elliot, Field Col. Mus. Chicago, Zool. Ser. III, No. 14, pp. 255-256, December, 1903.

Description-Color in fresh pelage: Top of head creamy buff with a slight shade of fawn color, lightly frosted on surface with gray; top of back a slightly paler shade of 


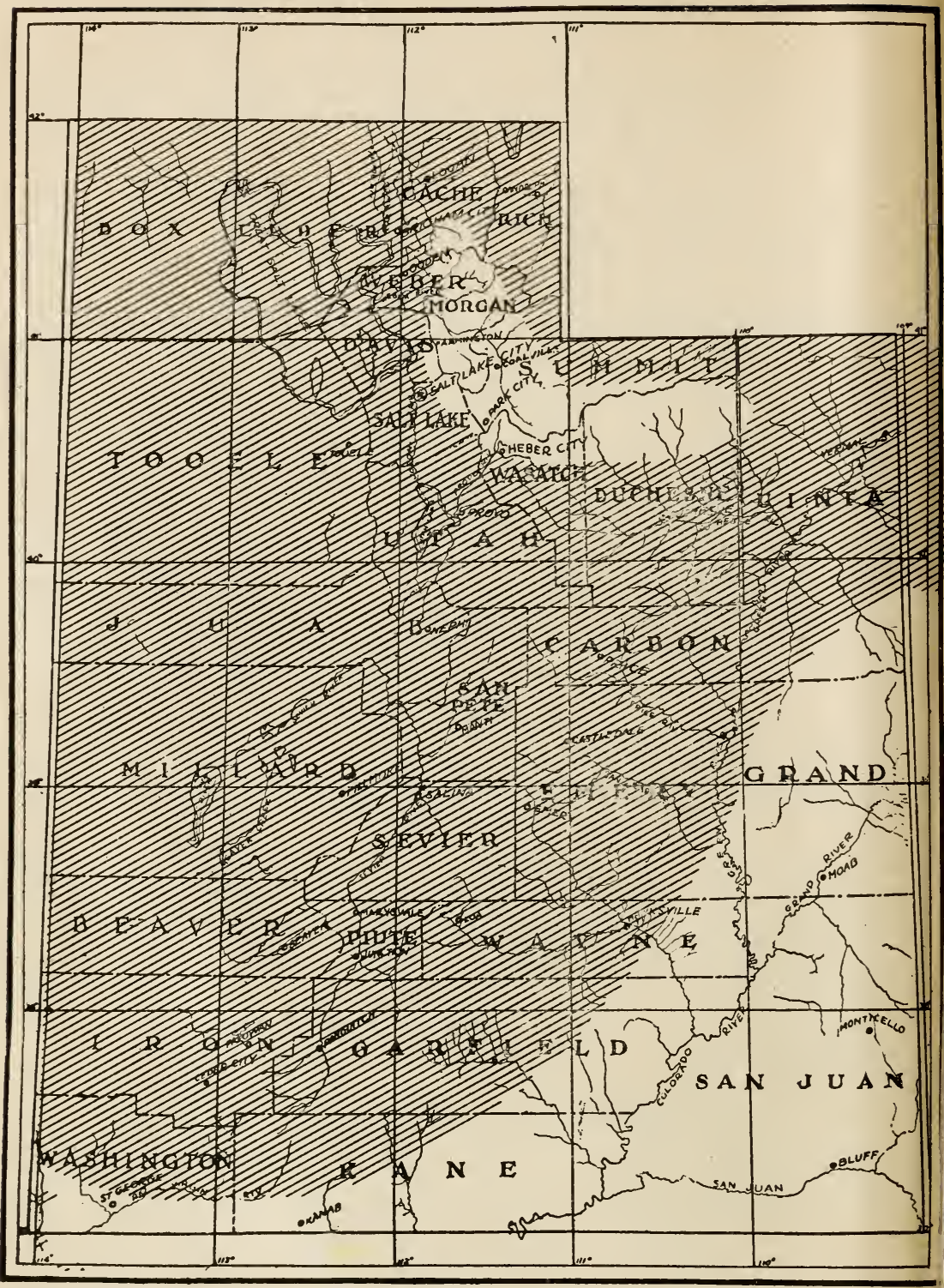

Map. No. 20.-Range of Black Hills Cottontail (SYLVILAGUS NUTTALL) GRANGERI Allen) in Utah. Based on map of E. W. Nelson. 
same creamy buff, darkened by an overlying wash of black; rump patch iron gray; top of tail dull buffy brownish; under side white; sides of head and body dull buffy gray, much paler and grayer than back; nape light rusty rufous; front and sides of fore legs bright, almost orange, rufous, varying to a slightly darker and more cinnamon rufous, but like hind legs averaging much brighter rufous in pinetis and shading into a paler, more rusty buffy on tops of fore feet; back and outside of lower hind legs similar to front of fore legs, but rufous deeper and richer; outside of hind feet more or less strongly shaded with rusty; tops of hind feet white, underlaid with a tinge of rusty buffy; underside of neck dull creamy buffy, varying to a dull ochraceous buffy, with a wash or grayish on surface; rest of under parts pure white; sides of neck dull grayish creamy buff underlaid and tinged with a dull reddish brown, ears dull grayish, edged about terminal third with black. Worn pelage: Upper parts bleached to grayish white, underlaid by varying shades of the buffy brown underfur, which often give badly worn specimens a much darker or browner appearance, very different from freshly pelaged ones; legs average brighter rufous; outside of ears duller and browner; nape deeper and richer rusty ; rump patch less distinct. Postjuvenal pelage: Darker and more grizzled grayish buffy than adults, with rump patch much less distinct; sides of body only slightly grayer than back; legs bright rufous, as in adults. Juvenal pelage: Dark dull grayish buffy; rather darker than in the young of pinetis; nape and legs duller and paler rusty, often becoming rusty buffy on legs and feet. (Nelson.)

Distribution-Western South Dakota, most of Montana and Wyoming; most of the sagebrush plains of Idaho, Nevada, mountains of middle eastern California; most of Utah; northwestern Colorado, north into Canada. Specimens have been taken in Utah at Bear Lake, Henry mountains, Helper, Ogden Hot Springs, Laketown, Nephi, Ogden, Panguitch, and upper Kanab.

Habits-Meek and timid in nature, the cottontail is nevertheless one of the most interesting animals of the woods. Rabbits in general vary little among themselves, but are, however, sharply separated from other species of the gnawing tribe. The soles of a rabbit's feet are not bare like those of most rodents; but are covered with haira fact which accounts for the lack of sharp definition in their footprints. Behind the two big front teeth of the rabbit's upper jaw are another pair of small teeth, which 


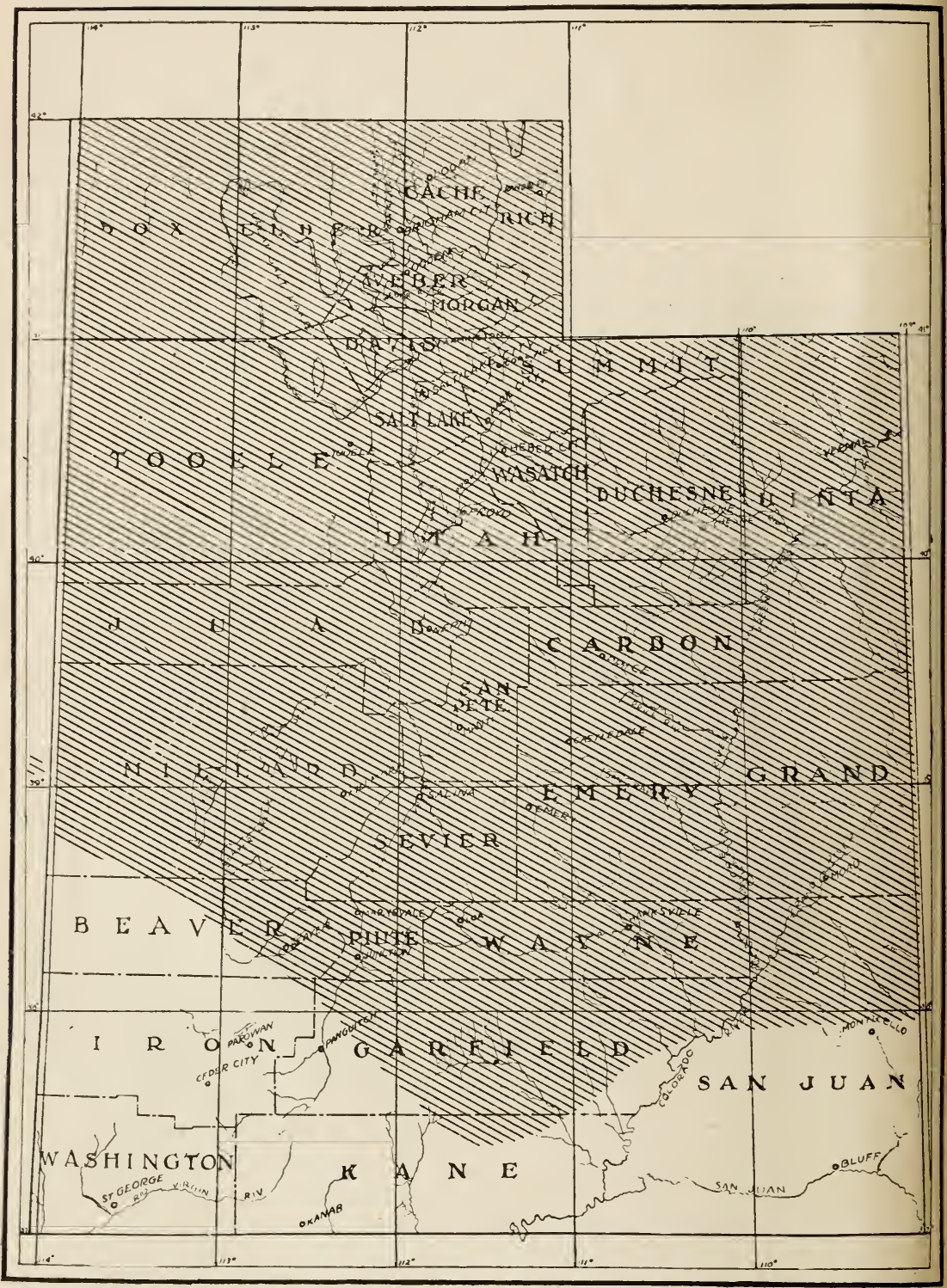

Map No. 21.-Range of Western White-tailed Jack Rabbit (LEPUS CAMPESTRIS TOWNSENDI Bachman) in Utah. Based on map of E. W. Nelson. 
do not reach far enough down to be of any use. These inservient molars show that the ancestral rabbits of prehistoric days had four large front teeth instead of two.

A rabbit's front leg bones are so constituted that they cannot be turned inward and used as hands when the animal is feeding. Thus a rabbit may reach high to nibble some tid bit, but its feet hang helpless during the process. In fact the rabbit does not use its front feet except when running and in manifesting anger by stamping.

Briar grown berry patches, sage covered ravines, isolated clumps of bushes, whether on the roadside or on the mountain slope-these are the haunts of the cottontail. Creek bottoms and places of impenetrable foliage suit his fancy to a nicety; winter and summer, he thrives on a woodland only a few rods square.

The food of the cottontail is more varied than that of most other animals, as it includes in summer, fruit, grasses, vegetables, and almost any herbaceous bit its fancy selects, and, in winter, dead grass, buds, the bark of poplar, willow, dwarf birch trees and occasionally tamarac. Sometimes it eats white cedar and spruce leaves.

\section{WESTERN WHITE-TAILED JACK RABBIT}

\section{LEPUS CAMPESTRIS TOWNSENDI (Bachman)}

Lepus townsendi Bachman, Journ. Acad. Nat. Sci. Phila. VIII, pt. I, pp. 90-94, pl. II, 1839.

Description-Color of fresh summer pelage: Head and upper parts of body nearly uniform dark gray, varying from an almost silvery tone to a dull and slightly pinkish gray with an underlying brownish shade; underfur tipped with dusky brownish, darker and less buffy than in campestris; front fore legs and tops of fore feet dull grizzled buffy gray, sometimes becoming dingy buffy on tops of feet, outside of hind legs varying from plain dull gray to drab gray; tail white, sometimes with a considerable amount of dusky or black, forming a narrow but wellmarked median line on top; tops of hind feet white, sometimes with a slight mixture of gray, or a little buffy about toes; nape dingy gray, sometimes with a smoky brown or dull buffy brown suffusion; front half of outside of ears dusky gray; posterior half white with a distinctly more restricted black tip than in sierras or campestris; inside of ear with a dusky area along posterior side and bordered 
anteriorly with dull rather pale ochraceous buffy; posteriorly bordered with white, the latter sometimes suffused with deep buffy; tip of ears in front edged with black; orbital area and sides of nose sometimes more or less strongly shaded with cinnamon buffy; underside of neck dull drab grayish shaded with brownish or dull buffy, distinctly less yellowish and more brownish gray than in campestris. Color of winter pelage: Specimens from Utah, Nevada and thence north became white in winter and practically indistinguishable from campestris except by smaller size and less black on tips of ears; winter specimens from southwestern Colorado become much more whitish than in summer, but, as in the case of campestris east of the mountains in that State, only a partial change takes place. In strong contrast to the bright yellowish buffy backs of Colorado specimens of campestris in winter, townsendi from the same state at this season becomes much paler or more whitish on shoulders, sides of body, and rump, and paler buffy gray on top of head and back; the ears become paler and grayer than in summer; nape grayish white; top of tail white with dusky along median line on top, varying from scattered hairs to a strong well-marked black band in several specimens from Coventry, in one case equaling ordinary texianus in amount of black; top of fore feet and legs dingy buffy brownish or dull grayish buffy; outside of hind legs whitish or dull whitish gray; underside of neck varying from dull browish buffy to dull ecru drab, always more or less strongly washed with whitish or lighter buffy; well-marked rump patch dull whitish, varying to pale dull iron gray. (Nelson)

Distribution-Great Basin region, including east slope of Cascade range, and thence east to Rocky Mountains, occupying eastern Washington and Oregon north to Fairview, British Columbia; and from the northeastern corner of California easterly to northern Nevada, western and southern Idaho, extreme southwestern Wyoming, most of Utah, and Colorado from western border to summit of Rocky Mountains. Vertical range from 1,000 to 12,000 feet. Specimens have been taken in Utah from Kanab, Ogden and Salt Lake City, and huridreds are killed annually for the market at the northern end of Great Salt Lake and in Tooele and Utah counties.

Jack rabbit skins are at present worth from 75 cents to 35 cents a pound. The hatters of the East have recently discovered that by a new method the fur of western jack rabbits is suitable for hats. Heretofore most of the skins they used were imported from other countries. 


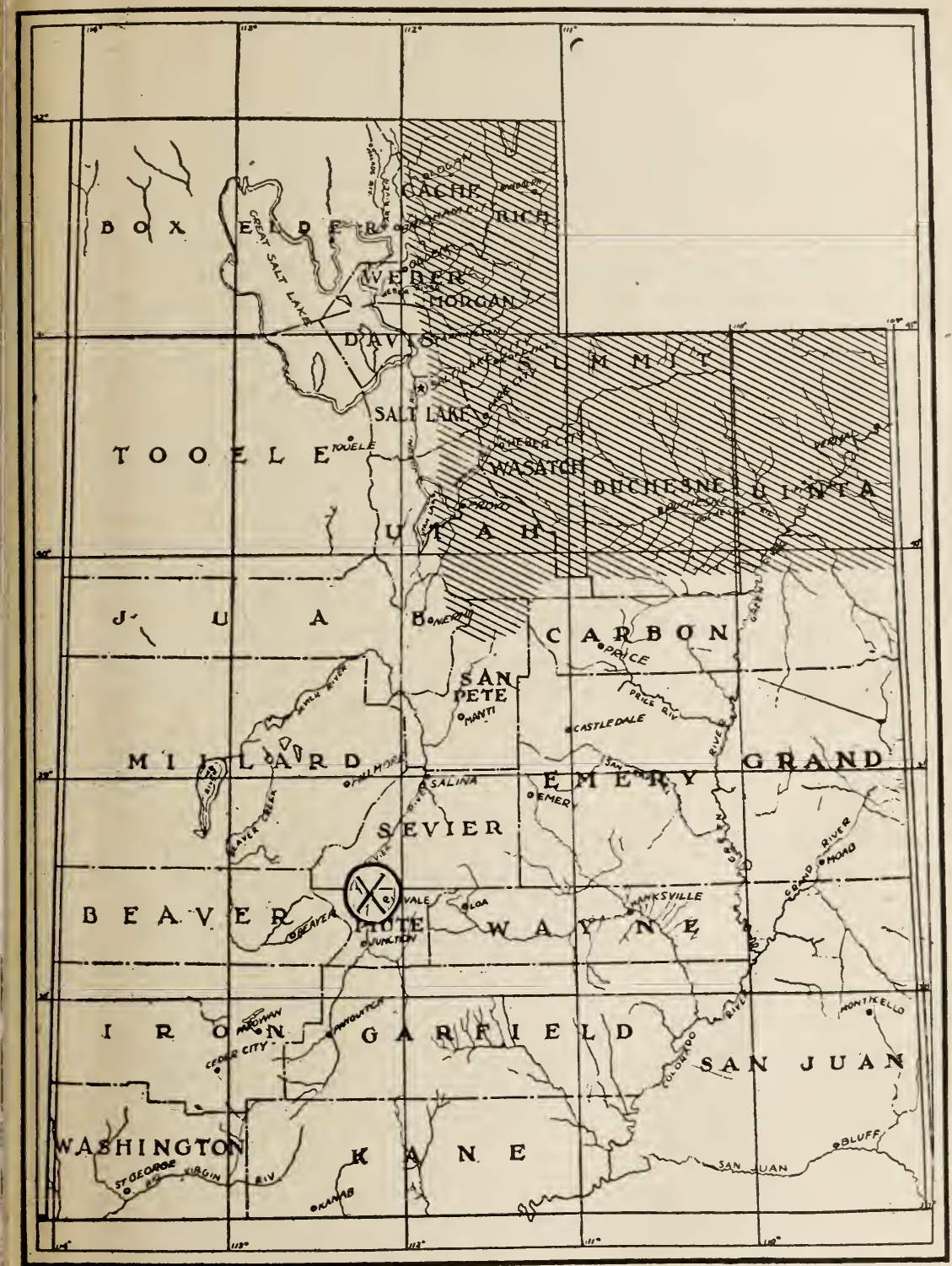

Map No. 22.-Range of Rocky Mountain Snowshoe Rabbit (LEPUS BAIRDI Hayden) in Utah. Based on map of $\mathbf{E}$. W. Nelson and records of Claude T. Barnes. 


\section{ROCKY MOUNTAIN SNOWSHOE RABBIT}

\section{LEPUS BAIRDI (Hayden)}

Lepus bairdi Hayden, Am. Naturalist, III, pp. 115-116, I text fig., May, 1869.

Description-Color in summer pelage: Upperparts of body varying from dusky slightly buffy grayish brown to rusty cinnamon brown; wash of dusky strongest along top of back, about as in americanus and rump even more blackish (about as in macfarlani); top of tail black; sides of body like back; top and sides of head deep reddish cinnamon mixed with dusky on crown and cheeks, but nearly pure about eyes and sides of nose; the color of head usually brighter and contrasting with the dulled and darker color of body; basal front half of ears similar to top of head and shading into dusky near tip; posterior half of ears on outside dingy grayish on basal part and becoming blackish on terminal half; inside of ears dusky brownish with a wellmarked white border around entire margin; nape dusky brown, duller than back; front and hind feet usually white, but one Idaho and one Wallawa Lake, Oregon, specimen have fore feet and legs and front border of thighs similar to head and tops of hind feet whitish with a thin mixture of rusty cinnamon hairs; underside of neck similar to sides of body but often much deeper or more richly colored; rest of underparts snowy white with color of flanks sometimes extending in on sides of abdomen. Postjuvenal pelage: (A half-grown specimen from Big Snowy Mountains, Montana) Nearly uniform dull, slightly ochraceous, buffy, clearest about eyes and on feet; underside of neck rich rusty cinnamon. Another speicmen of same age from the Snowy Mountains much duller and grayer than the one described and about intermediate between it and one from Wyoming. Winter pelage: Entirely pure white, except a narrow dusky border to tip of ears, and sometimes salmon varying to pale salmon buff. (Nelson)

Distribution-Higher parts of Rocky Mountains from Idaho, Montana, and extreme eastern Washington and Oregon, southeast through western Wyoming, eastern Utah, and middle Colorado to central New Mexico. Vertical range from about 8,000 feet to timerline. The specimens thus far taken in Utah are from the Wasatch and Uinta Mountains. Prof. Marcus E. Jones, however, states that he has seen them at Marysvale, Utah, and though specimens are 
not at hand the report will undoubtedly prove authentic. I have taken specimens in City Creek Canyon within the corporate limits of Salt Lake City.

Habits-This large-footed hare prefers thick willowcopses; hence each individual passes its entire life in a glen of only a few hundred yards radius. It is not very sociable with others of its kind though of course not avoiding them. It squeals when frightened. It mates early in March, the nest being made usually under a labryinth of underbrush. The young, usually two though sometimes three in number, leave the nest after ten or twelve days and at three weeks leave probably never to return.

This rabbit feeds mostly after sundown or before sunrise. It dresses its coat after the manner of a housecat; but is not so clean about its den which eventually becomes a source of disease. Its broad feet permit travel in winter as easily as in summer and hence it changes its habits little with the seasons. During the summer it feeds on grass, clover and other edible green things; but in winter it subsists on dry grass, buds and the bark of poplar, birch, willow and tamarac trees, as well as the leaves of white cedar and spruce.

\section{COLORADO DESERT JACK RABBIT}

\section{LEPUS CALIFORNICUS DESERTICOLA (Mearns)}

Lepus texianus deserticola Mearns, Proc. U. S. Nat. Mus. XVIII, No. 1081, pp. 564-565, June 24, 1896.

Description-Color in fresh winter pelage: Top of head and back pale ash gray, often almost whitish, only a little darkened by black tips to hairs, and often tinged with pale buff; sides of head and body paler than back; area about eyes pale buff or buffy white; front half of ears varies from grayish cream buff to pale buffy gray; posterior half of ears clear grayish white, usually with a rather poorly defined blackish patch about an inch long at tips (sometimes this patch nearly obsolete); the black area not strongly marked about border of ears at extreme tip, as in most other forms of this species; inside of ears bordered on front edges with a fringe of long whitish hairs, at tips by a narrow velvety border of buff, and along posterior edges with white; inside of ears brownish gray near posterior border and plain gray elsewhere; nape pale dull cin- 
namon varying to fawn color and pale grayish drab; top of tail and line down base of rump black; underside of tail dull, slightly yellowish, gray; lower part of shoulders and fore legs varying from pale buffy fawn color to pale dull pinkish buff; tops of fore feet varying from pale dull gray to yellowish white; an indistinct band along sides of abdomen and lower border of flanks dull cinaceous buff, sometimes varying to pale cream buff with a slight vinaceous tinge; back and sides of hind legs dull ecru drab, shading into dull white, often tinged with dull buff on front of legs and tops of hind feet; underside of neck a little darker than fore legs and varying from pale buffy fawn color to cinaceous drab; rest of underside of body white, more or less strongly vinaceous buffy along border of flanks, as already noted; rump patch absent. In worn and faded pelage the upperparts become more whitish and the buffy on sides paler. (Nelson)

Distribution-Arid desert areas of northeastern lower California, and extreme northwestern Sonora, New Mexico, thence north through southeastern California, through most of Nevada, most of Utah, and southern Idaho, and east Phoenix and San Francisco mountains in Arizona. Vertical range from below sea level to 9,000 feet. Specimens have been taken in Utah from Beaver, Beaver Hills, Buckskin Valley, Cave Fort, Kelton, Loa, Nephi, Ogden and Provo. 


\section{Order CARNIVORA: Carnivores}

Family FELIDAE, Cats

\section{PUMA: MOUNTAIN LION}

\section{FELIS HIPPOLESTES (Merriam)}

Felix oregonensis Rafin., Atlantic Journ., 1, 1832, p. 62.

Felis hippolestes Merriam, Proc. Biol. Soc. Wash., XI, 1897, p. 219.

Felis hippolestes olympus Merr., Proc. Biol. Soc. Wash., XI, 1897, p. 220.

Felis hippolestes aztecus Merr., Proc. Wash. Acad. Sci. 111, 1901, p. 592.

Felis aztecus browni Merr., Proc. Biol. Soc. Wash., XVI, 1903, p. 73 .

Felis concolor oregonensis Elliot, Syn. N. A. Mamm., F. C. M. Pub., II, 1901, p. 204.

Description-Upper parts and sides pale fulvous brown, darkest in middle of back and tail; tip of tail black; face from nose to eyes grayish brown; a pale patch over each eye; back of ears blackish; chin, lips (except dark patch at base of whiskers) throat, breast, inner side of forelegs, inguinal region, and hinder part of belly solid white; under side of tail grayish white. (Merriam type Felis hippolestes.)

Distribution-Mountain lions are distributed over the greater part of the State of Utah. In 1915 bounty was paid on 50 animals killed in the following counties: Beaver, 13; Garfield, 2; Grand, 2; Iron, 1; Millard, 9; Salt Lake, 5; Sanpete, 1; Sevier, 1; Uintah, 5; Wasatch, 3; Washington, 8. In 1916 bounty was paid on 34 as follows: Beaver, 1; Garfield, 3; Grand, 1; Iron, 3; Kane, 1; Piute, 3; Salt Lake, 1 ; Sevier, 1; Tooele, 5; Wasatch, 3, and Washington, 11. I have seen mountain lion tracks in Emmigration canyon only a few miles from Salt Lake City, and in 1917 a lion was killed just west of the city about twelve miles. A. W. Jenson of Provo estimates that there are 25 cougars in the Uinta forest while Clinton Milne of St. George says they are numerous and on the increase in Washington county where they do much damage to deer, sheep and colts. B. E. Mattsson says mountain lions are to be found on the lower ranges of the Manti forest, particularly on ranges used for lambing 
purposes. He reports very few domestic animals have been killed by them during the past five years. George $\mathrm{H}$. Barney of Escalante informs me that they are numerous along the south and east boundary of the Escalante forest. They there range just inside the forest and in the rough, ledgy country to the Colorado river. J. W. Humphrey of Panguitch says that they are numerous on the mountains on both sides of the Sevier river valley in Garfield and Kane counties. William M. Mace of St. George writes that they are found in the Dixie forest, particularly in the vicinity of the Pine valley mountains and also in the northeastern part of the county. He estimates that there are from 100 to 150 in Washington county. E. C. Shepard of Logan estimates that there are 50 in the Cache national forest, and William M. Anderson reports a few along the rough breaks adjacent to Green river.

C. A. Mattsson of Salina says: "The large bounties that have been offered for mountain lions have resulted in their extermination on some of the principal ranges of the Fish Lake forest. However, there are a few lions still found in the ledges and rough country immediately to the north and south of Salina canyon. The tracks and other indications also show that there are a few lions on the East desert which lies just east of the Coal range. These lions have done much to prevent an increase of deer."

Of several hundred Utah cougar skins mounted by $\mathrm{Mr}$. F. A. Wrathall he is able to note no constant difference in coloration between those taken from the southern and those from the northern part of the State. The finest skins he receives come, however, from the vicinity of Kanab and from Tooele county.

Habits-The names of the mountain lion are legion: For instance, what is called the "panther" in Texas, the "Mexican lion" in the south, the "cougar" in the middle west, the "deer tiger" in Guiana, "puma" among scientists, "painter" in some parts of the East, and "catamount" is merely the mountain lion. Other names of the cougar are as various as the works of Daedalus, a few of the more picturesque among them, native and otherwise, being as follows: "Chimbiea," "lion," "yutin," "miztli," "pagi," "red tiger," "American lion," "silver lion," "Brazilian cat," "brown tiger," "mischipischu," "ingronga," "gauzuara." "ingrongasinda," "Schunta-Haschka" and "Ihtupah-achati."

In both size and color the cougar resembles the female African lion though there is no comparison in ferocity. The African lion cannot climb a tree. 
The cougar's size is, however, somewhat in dispute, Roosevelt insisting in his "With the Cougar Hounds" that it never "comes anywhere near being nine feet in length." This, I am sure, however, is untrue as I have myself measured a skin that went nine feet five inches tip to tip. In response to an inquiry, Buffalo Jones, the noted cougar hunter, wrote me that the largest mountain lion he "ever saw measured ten feet four inches, from tip to tip, after it was skinned." Phineas Bodily of Kaysville tells me that he once killed a lion that measured nine feet six inches. James G. Needham of Galesburg, Illinois, according to information furnished True, killed one that measured nine feet one inch. The American Field, Vol. 24, 1885, p. 486, records one that went ten feet, and Forest and Stream, Vol. 19, 1882, p. 127, mentions one that measured eleven feet three inches! In Outdoor Life, Vol. XLII, No. 4, October, 1918, p. 243, Addison M. Powell gives the following measurements of different cougars he knows of: Nine feet 4 inches, 10 feet 6 inches. He adds: "I possibly could get one hundred names of reliable men who have killed panthers-the Pacific Coast variety, the skins of which measured more than nine feet and many more than ten feet."

The young mountain lion, pale rusty gray in color, is covered with numerous distinct round blotches like those of the leopard. The kittens, usually two in number, remain with the mother until they are grown or have at least learned to hunt. They are born at various times throughout the year and do not open their eyes until the ninth or tenth day.

The lair is usually a shallow cavern on the face of some inaccessible cliff or ledge but if there are no rocks about, a bed of sticks, weeds, mosses, leaves, and grasses is built in a dense thicket.

Thomas Abbott, a Utah pioneer, tells me that in early days in Utah he once saw three mountain lions chasing a deer, one running at each side and the other at the rear. Others inform me that they have seen them thus chasing deer up a canyon. Usually, however, the cougar is a solitary wanderer. Always shy, always alert, one may sneak about for hours without being either seen or heard.

It is said that the cougar is the only animal feared by the grizzly bear; yet a small dog when with a hunter can usually chase a mountain lion up a tree. Even a female cougar will desert her young after a brief encounter with hounds.

There are about a dozen authentic records of instances where a cougar has killed a man, and many instances of 
attacks on children; yet Hornaday, who can always be relied upon in matters concerning mammals, says it is less to be dreaded than a savage dog. Of course there are exceptions to all rules governing the habits of wild animals; in fact, I knew a trapper in Idaho by the name of Frank Peet, who habitually shot grizzlies yet had been followed by a cougar in such a uncanny manner on several occasions that he feared this animal more than any other in the woods.

When treed a cougar will snarl and growl in low thunderous tones and at the death may even squall. In defending itself it strikes with its forepaw or, lying on its back, tries to rip open its antagonist with its claws.

In a single night a cougar may ravage a stock farm wreaking its desires particularly on colts, sheep, calves and pigs. Phineas Bodily tells me that he saw one kill ten sheep in as many minutes; it bit each one in the back of the head and the whole performance was over before any sounds were made. He has known a cougar to jump a nine-foot fence, taking a grown sheep with it.

\section{CANADA LYNX \\ FELIS CANADENSIS (Kerr)}

Lynx canadensis Kerr, Anim. Kingd. 1792, p. 32, disc. p. 157. Felis canadensis Elliot, Syn. N. Am. Mamm. F. C. M. Pub. II, 1901, p. 295. Zool. Ser.

Description-Body stout, and legs very long, with very large feet. The fur is dense and very long. Color light gray, base of hairs rufous, giving a reddish tinge to the coat; top of head and back darkest; ears behind black with a gray patch, and tufts of black hairs projecting upwards from the tips; under parts white; tip of tail black all round. Total length 37 ; tail vert. 4.75. (Merriam.)

Distribution-In 1915 sixty-one lynx were taken in Utah and reported for the payment of bounty, thirty-one of them coming from Sevier County, and the remainder from Beaver, Uintah, San Pete, Salt Lake, Rich, Emery, Duchesne, and Carbon Counties. In 1916 forty-two were killed, thirteen coming from Tooele County and the remainder from Box Elder, Carbon, Duchesne, Iron, Morgan, Salt Lake, San Pete, Summit, Uinta, Utah, Wasatch, Wayne, and Beaver Counties. Clinton Milne says that there are a few in Washington County. 
Habits-This animal is very destructive to smaller wild game and to young lambs. An occasional lynx is found in the Panguitch district, according to J. W. Humphrey; and E. C. Shepard estimates that there are fifty in the Cache national forest. They are, however, plentiful, according to William M. Anderson of Vernal, throughout the whole Uintah mountains. A. W. Jensen estimates that there are fifty in the Uinta forest district alone.

Harry Krupp has killed several animals of this species in Utah just south of the Wyoming line, several of the skins being in the possession of F. A. Wrathall. The big feet of this animal readily distinguish it from the wild cats.

Heavily furred lynx skins of large size bring the trapper as high as $\$ 60.00$ each; and the very poorest skins are worth about $\$ 2.00$ each.

\section{UINTA MOUNTAINS LYNX: MOUNTAIN WILD CAT}

\section{FELIS UINTA (Merriam)}

Lynx uinta Merriam, Proc. Biol. Soc. Wash. XV, 1902, p. 70.

Description-Size large; tail very long with two black subterminal bands, black tips. Skull long, narrow, sagittal crest present; ascending arm of maxillary broad, under jaw heavy, teeth small. Color: Above buffy grizzled with gray and black; beneath white with black spots, these becoming bands on inner sides of arms and thighs; throat fulvous, crossed by a fulvous brown band; V-shaped black mark on anterior part of throat; tail with two or three blackish bands above the black tip. (Elliot.)

Distribution-The type locality of this cat is the south slope of the Uinta mountains, Uinta county, Wyoming. Dr. Merriam informs me that Lynx uinta is doubtless confined to the high timber mountains in this state.

\section{BAILEY'S LYNX}

\section{LYNX BAILEYI (Merriam)}

Lynx baileyi Merriam, N. A. Fauna, No. 3, 1890, p. 79.

Felis rufa baileyi Elliot, Syn, N. A. Mamm., F. C. M. Pub., 11, 1901 , p. 297.

Description-Lynx baileyi differs from Lynx rufus of the eastern United States in being uniformly paler above 
and in having a shorter tail and softer fur. The upper parts are everywhere suffused with a buffy tint, and the dark markings are decreased in area or altogether suppressed. Thus the blackish marblings of the face and forehead are obsolete, and the black half ring at the tip of the tail is not more than half the width of that of $\mathbf{L}$. rufus. On the other hand the anterior border of the ear is distinctly whitish, in marked contrast to the black immediately behind it, while in L. rufus the same border is dark tawny brown. The white hind toes of L. rufus are absent. (Merriam.)

Distribution-Dr. C. Hart Merriam informs me that Lynx baileyi is the common bob-cat of southern Utah and probably of the greater part of the state.

Wild cats are quite common on the lower ranges of the Manti forest (B. E. Mattsson) and are common all over the Escalante forest and in the rough breaks to the south and east (George E. Barney). There are probably a hundred in the Cache national forest (E. C. Shepard); and they appear in considerable numbers in the mountains on both sides of the Sevier River valley in Garfield and Kane counties (J. W. Humphrey). Bob-cats are fairly plentiful in the Vernal country, being located generally around the boundaries of the Ashley forest, between the farm lands and the higher areas (William M. Anderson). C. A. Mattsson of Salina says: "The wild cat, bob-cat or bay lynx, as it is variously called in different parts of the country, is one of the most widely distributed and best known animals in this vicinity. It has been seen on the hills near the agricultural districts of the valleys and during the summer seasons on the high elevations of the mountains in the Fish Lake national forest. It is most numerous near rock slides, lava beds, in ledges, rough canyons, and in the more inaccessible parts of the mountain ranges. Ordinarily the wild cat seems to be rather uncommon, but its nocturnal habits usually prevent its real numbers from being known. However, on the Thousand Lake mountains, and on the more inaccessible parts of the Fish Lake forest it is not uncommonly seen abroad by day."

Mr. F. A. Wrathall informs me that this animal is very common if one may judge from the constant supply of skins sent him for mounting from various parts of the state.

S. B. Locke says that they are well distributed over the cedar and pinyon covered districts of San Juan county.

Habits-Despiteful, alert, and as furious as a demon when actually cornered, but, at times, as warm hearted as 
the Good Samaritan-such is the wild cat according to circumstances and mood. Look at the house cat when it lies serenely before the hearth-it purrs affably with almost an angelic sweetness in its big round eyes-then, watch it when a strange dog enters-it assumes a fiendish aspect, spits, growls, and emits bitter enmity from every hair. You have seen a dimunitive wild cat; for a friend of mine, a furrier, has a wild cat that is so good humored that he can rub his head against its cheek while a stranger meets a most misgiving rush and snarl.

The wild cat prowls about the foothills in search of birds, squirrels, mice, grouse, cottontails, and, in fact, any small game, not excepting snakes, frogs and insects. Unless starving it refuses to attack a skunk or the porcupine, though it may kill a cross fox. which, not being broad footed, sinks in the snow and cannot flee. As a rule a wild cat will rush up a tree at sight of a small dog. In capturing a prairie dog it evinces unbounded patience, crouched for hours behind a rock until its victim, thinking it has passed, works up sufficient courage to scamper a few yards from its hole. In eating, a wild cat crunches and swallows bones as well as meat; and, if disturbed, emits a low, humming growl, smoother and softer than the growl of a dog, yet fiercely defiant and uncanny.

If about to fight with each other, wild cats twitch their tails violently, put their ears back, and hold their paws ready to strike, snarling and rumbling all the while. Their teeth and claws are over half an inch long and beautifully formed.

The home of the wild cat is usually in a hollow stump, or in a thick tangled coppice between the interlocking branches of some falled tree. Here on a soft bed of moss and dry grass, the ill-tempered kittens, usually three, are born, though one may be devoured at once by the incomprehensible mother. In two or three months the kittens are weaned and taught to hunt ready to face the chill winds and scanty food of winter.

The flesh of the wild cat is white, tender and quite like veal.

The skins of this animal bring the trapper from 35 cents to $\$ 20.00$ each according to quality and size. 


\section{Family CANIDAE, Dogs, Wolves, Foxes.}

Subfamily CANINAE

\section{WOLF}

\section{CANIS OCCIDENTALIS (Richardson)}

Canis lupus occidentalis Richard., Faun. Bor. Am., Mamm., 1,1829 , p. 60 .

Canis occidentalis Elliot, Syn. N. Am. Mamm., F. C. M. Pub., 11,1901, p. 300 .

Description-Skin of male in general, a dull, yellowish white, becoming nearly pure white on cheeks, chest, and inside of hind legs. The upper part of the muzzle, crown, and outer side of each limb and the entire plantar surface of each foot is tinged a clear pale sienna. On the, backs of the ears the sienna is much deeper and stronger. Beginning on the muzzle between the eyes are many black-tipped hairs, which increase in length and number and continue overhead, upper neck, shoulder, and back to the basal third of the tail, where they end in a black spot an inch wide and two inches long. After this the tail hairs are faintly tipped brownish-black; the tail itself ending in a dark tip of blackish hairs, with a few white ones interspersed. The under fur is brownish gray on the under parts, becoming much darker on the limbs and much browner and darker on upper parts generally. The dark spot on the tail near its base is formed by a curious tuft of black-tipped hairs, below which there is no wool or under-fur, but evidently a skin-odor gland. The claws are dark horn color. Individuals are found of every shade, from white deep yellow and almost black. Its size, short tail, short, wide spread ears, and pale, straw-colored eyes are characteristic. (Seton.) When seen at home, the gray wolf can readily be distinguished from the coyote, even at a distance, by the way it carries its tail-pointed above the horizon. (Hornaday.)

Distribution-In 1915, bounty was paid on 72 wolves in Utah in the following counties: Carbon 3, Duchesne 2, Grand 17, Kane 1, Rich 15, San Juan 3, Summit 2, Uintah 9, Wasatch 19, and Weber 1. In 1916 bounty was paid on 79 wolves as follows: Carbon county 1.3, Duchesne 5, Emery 2, Grand 8, Juab 1, Rich 5, San Juan 26, Sevier 4, Uintah 12, Wayne 1. The gray wolf is almost extinct in the St. George district though one was recently taken near Leny's ranch about twelve miles from Enterprise. This wolf had been 
doing considerable damage, it being estimated that it killed twenty-five head of cattle during the past year. (Clinton Milne.) It is estimated by A. W. Jensen that there are 30 wolves in the Uinta forest.

A gray wolf was killed in the limits of Salt Lake City in July, 1918. According to William M. Anderson of Vernal the gray wolf is very scarce in that country. Occasionally one is taken by a trapper, but wolves do not remain long in that vicinity. C. A. Mattsson of Salina says: "A few years ago there were a number of gray wolves on the East Desert and on the Thousand Lake Mountain. These wolves killed a number of cattle on the desert each winter and took at least 50 per cent of the calf crop during the summer. The large bounties offered by stockmen induced two trappers to spend part of two winters in the desert. They killed two large wolves and eleven pups. There are a few remaining in that vicinity."

S. B. Locke says that wolves occur on the east side of the La Sal mountains, in Dry Valley and both north and south of Blue mountains. They do considerable damage in Hart Draw and in the region south of Elk mountains.

Habits-When buffaloes roamed in countless numbers over the American plains, thousands of gray wolves stalked in their wake, devouring the lagging weak and tearing the eyes out of the old bulls, which were too strong to be vanquished save by hours of torture and laceration. As the herds of majestic buffaloes succumbed to the encroachment of man, the gray wolves for a time faced extinction; but cattle ranges and an acquired wariness of man at last placed them on a permanent basis once again.

Probably no other animal has so wide an individual range, for being a swift footed flesh eater the gray wolf necessarily covers a big field in his wanderings. Wolves are the most sociable of beasts of prey; packs of dozens sometimes being seen engaged in the same hunt.

The wolf mating season begins the last week of January and lasts until the first week of March; it is probable that pairs are formed for life as it is certain that the male assists in raising the cubs. Two old wolves, never more, hover about a single den.

The den is usually a natural cave, a hollow log or stump, or a hole in the ground dug out by the parents. A badger hole may be enlarged, but in any case the bed is placed close to the surface and is never lined even though hay and other suitable material be plentiful. Lining har- 
bors parasites. The period of gestation is 63 days, and the young, 3 to 13 , but usually 6 or 7 , are blind at birth and even until the ninth day.

A wolf mother will never kill and eat her young as will a coyote at times. In fact a coyote will eat her own young when they have died from other causes. Cases are known where one female wolf has adopted the young of another mother who had for some cause been compelled to leave them. When born the young whine and are answered by the mother in the same tone.

Wolves fear man and rifles these days; and a wolf would rather starve than touch a carcass on which has been left a horseshoe, handkerchief or something of the sort.

A gray wolf is the shyest animal that roams the Utah wilds, not even the cougar being more wary. In the days of bows and arrows human beings were attacked by wolves; but such occurrences are very rare now. A few years back, however, a boy at Price, Utah, was molested for a time by a wolf that sprang beside his horse, but no harm was done.

A wolf's menu consists of everything from mouse to moose. It gorges on mice during the summer; but it has to stalk bigger game when the snow flies. It eats carrion readily; and will watch all day beside its buried cache. All wolves roll on carrion as do dogs seemingly enjoying reeking in the foulest stench. Yet they will lick blood stains, pull out burrs and otherwise clean themselves.

The usual cry of a wolf is a long, smooth howl, musical but weird, and quite indistinguishable from the howl of a large dog. When on the chase its call vibrates between two notes and becomes a combination of short barks and a howl at the finish.

A single wolf can whip any number of dogs; in fact its jaws are so strong that one has been known to cut a half inch lasso rope through with one snap.

The pursuit of the wolf, where the animals are at all numerous, is a very profitable employment. The state and cattle association bounties sometimes reach as high as $\$ 100.00$ for each animal killed. The pelts are worth from $\$ 1.00$ to $\$ 28.00$ each according to size and quality. 


\section{ROBBER COYOTE: MOUNTAIN COYOTE}

\section{CANIS LESTES (Merriam)}

Canis lestes Merr., Proc. Biol. Soc. Wash., XI, 1897, p. 25.

Description-Size medium; ears and tail large; color similar to C.latrans; skull and teeth medium. Muzzle pale cinnamon rufous; top of head grizzled gray and ochraceous, crown, nape, and ears fulvous; rest of upper parts grayish buffy mixed with black; under parts whitish tinged with buff on belly; ruff tipped with black; fore and hind legs buffy ochraceous on outer side, whitish on inner, and on hind feet; tail broadly tipped with black; white beneath on basal third, ochraceous on remainder, the hairs tipped with black towards the black tip. (Elliot.)

Distribution-Southern British Columbia through Washington and Oregon to the plateau of northern Arizona and New Mexico, and to the Mexican boundary.

Habits-The habits of this large, dark, richly colored coyote are not unlike those of the coyote of the plains and valleys but its prey is somewhat different, consisting chiefly of dusky grouse, cottontails, and snowshoe rabbits and including also many deer and fawns. (Cary.)

\section{NOLAND'S RANCH COYOTE CANIS ESTOR (Merriam)}

Canis estor Merr., Proc. Biol. Soc. Wash., XI, 1897, p. 31.

Description-Size small, color pale; carnassial and molar teeth small. Muzzle pale fulvous, top of head gray and buff; upper parts buffy mixed with black; under parts whitish; ruff conspicuously black-tipped; outer side of fore legs bright buff, pale on inner side, and on fore feet; outer side of hind legs and feet buffy ochraceous; inner side of hind leg and upper surface of hind foot white; under side of tail ochraceous, white basally, hairs of distal half tipped with black; tip of tail black. (Elliot.)

Distribution-Deserts of eastern California, Nevada and Utah. The type locality of this species is. Noland's Ranch, San Juan River, Utah.

In order to show the general distribution and numbers of coyotes in Utah it will be necessary to give only the 
report of the bounty paid during the year 1916. During that year bounties were paid for the destruction of 18,515 coyotes for the following counties: Beaver, 864 ; Box Elder, 2133 ; Cache, 355; Carbon, 210 ; Davis, 52; Duchesne, 360 ; Emery, 522; Garfield, 370 ; Grand, 164; Iron, 2356 ; Juab, 1017; Kane, 377 ; Millard, 2105 ; Morgan, 171; Piute, 256 ; Rich, 429; Salt Lake, 282; San Juan, 338; Sanpete, 682 ; Sevier, 447 ; Summit, 652 ; Tooele, 985; Uintah, 1136 ; Utah, 745; Wasatch, 590; Washington, 399; Wayne, 298, and Weber, 220. Under the vigilant work of the Biological Survey there has recently been a marked decrease in the number of coyotes in this state.

Habits-Coyotes are less courageous and have less of the social instinct than gray wolves, and on the rare occasions when they do hunt in packs they form, no doubt, a family party, including the young of the year. They appear to pair more or less permanently and commonly hunt in couples. The young, sometimes numbering as many as fourteen, are born in a burrow dug in a bank, or in a den among broken rocks and ledges. Young animals are readily tamed, and it is entirely probable that some of the dogs found by early explorers among Western Indians may have descended from coyotes. (Nelson.)

Coyote skins are worth from $\$ 1.00$ to $\$ 28.00$ each according to size and quality. These are the prices offered by the raw fir dealers of St. Louis.

\section{LONG-TAILED FOX: WESTERN RED FOX}

\section{VULPES FULVA MACROURA (Baird)}

Vulpes utah Aud. and Bach. Pr. A. N. Sc. Ph. V, June 30, 1852; N. A. Quad. 111, 1853, 255.

Vulpes macrourus Baird, Stansb., Expl. Great Salt Lake, Utah, 1852, p. 309.

Vulpes pennsylvanica macroura Elliot, Syn. N. Am. Mamm. F. C. M. Pub., 11, 1901, p. 305.

Description-This magnificent fox, the finest species known, is an inhabitant of the central portions of North America, and is eminently remarkable for the beauty and excellence of its fur. Very similar in general appearance to the common red fox, its superiority in size will at once readily distinguish it. In the light variety the prevailing tint is rather a pale ochre yellow than a red, whence the 


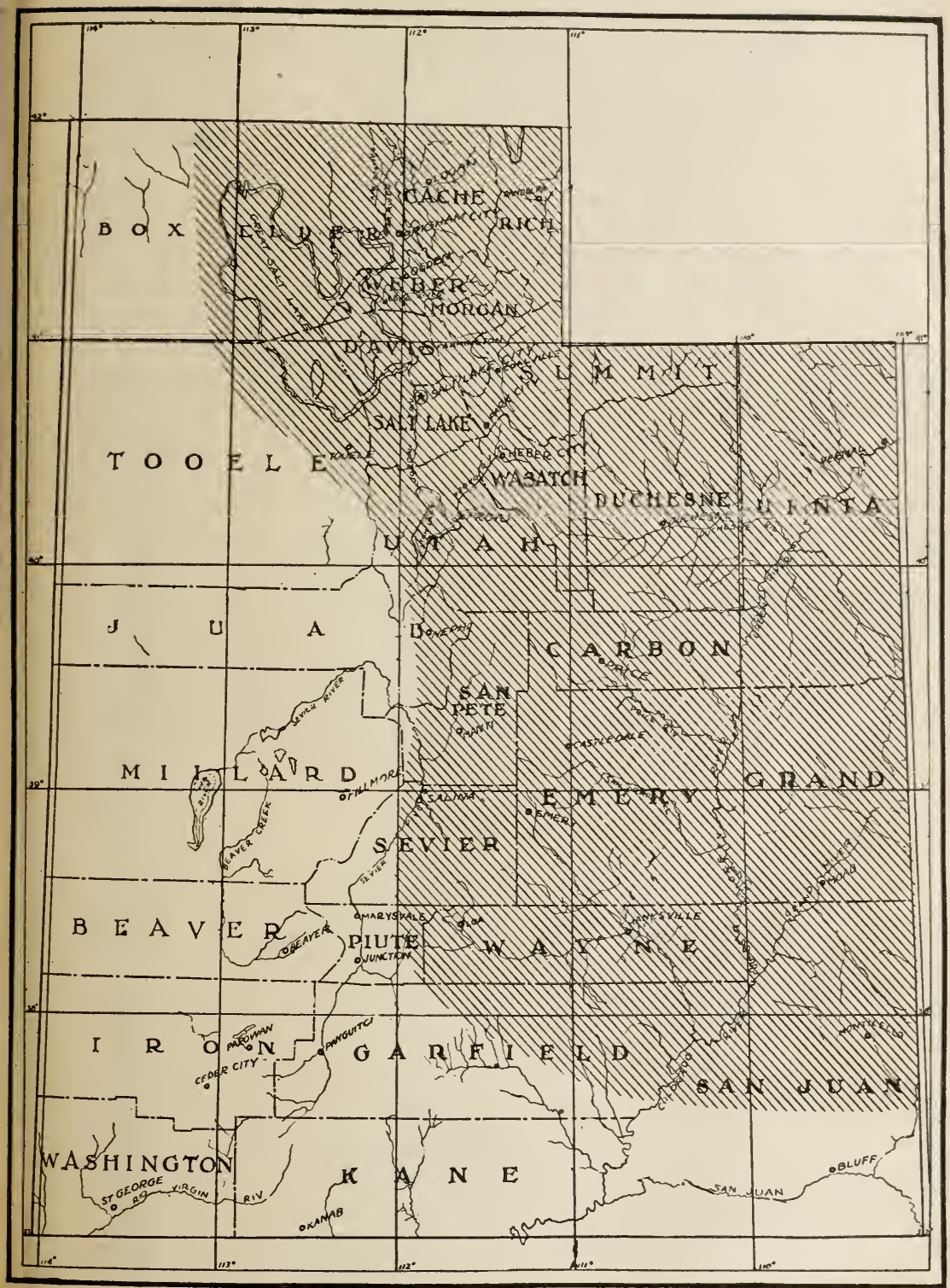

Map No. 23.-Range of Western Red Fox (VULPES FULVA MACROURA Baird) in Utah. Based on map of E. T. Seton and records by Claude T. Barnes. 
species might with great propriety be called the yellow fox. The yellow is brightest anteriorly on the sides; there is, however, a wash of reddish along the dorsal line. The hinder part of the back is variegated with yellowish white, this color annulating the long hairs, which are otherwise black at the base and rufous at the tip. The under fur is everywhere plumbeous at base, and of a chestnut color terminally along the dorsal line, changing through ochre yellow to yellowish white on the sides. There is, however, a darker yellowish cross on the shoulders, separating the yellowish white of the sides of body and neck. The upper part of the head is grizzled like the lower part of the back. The throat, chest, and under parts generally, including the whole belly and inside of legs and thighs are of a clear, yellowish white without any red, the plumbeous base of the wool showing occasionally through. The amount of white is thus greater than in the red fox. The base of the ears is yellow; the greater portion, however, of their convexity is uniform black. The tail is of a duller yellow than the body, lighter on the sides, the long hairs tipped with black, clouding the tail with this color; the tip of the tail is entirely yellowish white. The fore feet are black; on the hind feet, however, this color only extends in a narrow line on the anterior face. Nose to tip of tail, 33 inches. (Baird, type from Wasatch mountains near Salt Lake City.)

(2) BLACK FOX: SILVER FOX

\section{VULPES FULVA ARGENTATA (Shaw)}

Canis argentatus Shaw, Sen. Zool., 1, 1800, p. 325.

Vulpes pennsylvanica argentata Elliot, Syn. N. Am. Mamm. F. C. M. Pub., 11, 1901, p. 304.

Description-Uniform lustrous black with a distinct white tip to the tail. On the top and sides of the head, however, and on the posterior half of the back, including the outside of the thighs, the long hairs are grayish-silvery at the end (the extreme tips black) grizzling the back very conspicuously. The same feature is observable at the base of the tail and to some distance on the sides; it is also seen slightly on the shoulders. The under fur is of a sooty color, not very dark, however, and becoming lighter on the sides of the neck and flanks. (Baird.) Like the cross fox, this is only a color phase of the typical red fox, but commercially the two forms are so distinct, and so sharply defined in 
dollars and cents that they demand separate notice. This form inhabits the same localities as the cross fox, and is much given to mixing with it, whch causes many variations from their standard colors toward the typical red fox. (Hornaday.)

\section{(3) CROSS FOX}

\section{VULPES FULVUS DECUSSATUS (Desmarest)}

Canis decassatus Desm. Mamm., 1, 1820, p. 203.

Description-The cross fox is so called from the presence of a black cross formed by a dark band along the back, crossed by another on the shoulder. In general form it resembles the red variety closely, but is perhaps a little larger with more bushy tail. The under surface of the feet likewise are more densely covered with wooly hair. There is a good deal of yellowish rufous visible on the back and sides, which is quite vivid on the flanks and side of the neck. The upper part of the head (exclusive of muzzle) the posterior half of the back, with the outside of the shoulders and thighs, have the basal fur a dusky brown, darkest on the median line, the long hairs black, with a broad subterminal annulation of yellowish white of a much grayer tint on the head and shoulders, which variegates the color very much. The dorsal region between the shoulders is also similarly marked; but a great preponderance of black evident at the upper parts of the shoulders, causes the appearance of a black cross at this point. The sides of the neck and of the body are pure reddish yellow, the basal fur being nearly white. This color extends toward the median line of the back, just behind the shoulders, leaving an interval of only a few inches on the middle of the back, and relieving very much the posterior angles of the cross. The muzzle, legs and under parts generally, including the inside of the limbs, with the convexity of the ears, are black. The long tail hairs are grayish or yellowish red, and black at their tips, impressing this color on the exterior of the tail; the tip of the tail, however, is entirely white. (Baird.) "In my opinion a really typical cross fox is the handsomest fox in the world, far more beautiful than the much sought 'silver fox.'" (Hornaday.)

Distribution-The three varieties mentioned above are considered here together for the reason that the cross and the black foxes are really only color phases of the red 
fox, the type specimen of which was taken near Salt Lake City. Though the red fox is now and then seen pretty much throughout the State of Utah, very few people see them often enough to make many observations concerning them. One record I have of the occurrence of the black fox in this state is the account given me by Brigham Spencer of Moab; but the evidence is unquestionable. $\mathrm{He}$ states: "I was dairying in the Aquarius Plateau, Garfield County, Utah, in 1890. I was gathering calves one morning near the top of the mountain when I saw a black fox run into a hole beneath a spruce tree. As I approached she was very vicious; so I killed her. I then discovered five pups in the den. I killed them also. They were all coal black all over except a white tip at the end of the tail and a little whitish on each hip. I showed them to my family and to others in the neighborhood where they attracted considerable attention as no one had before seen foxes of that color. It was not until too late that we learned the great value of the pelts."

Several cross foxes have been taken from the Middle Desert near the Thousand Lake Mountain. Dr. Hornaday states in his invaluable work that the cross fox is "occasionally found in Idaho and Utah," though he informs me that at this late date he cannot recall upon just what data the statement was based, adding, however, "in view of the occasional occurences of cross foxes as color phases of Vulpes macrourus, the type locality of which is Utah, it is perfectly certain that before they were all killed off, cross foxes occured in Utah."

It is largely through the efforts of Dr. Hornaday and a few others that America is fast awakening to the fact that unless a halt is called on indiscriminate shooting there will soon be very few large mammals left except in museums.

S. B. Locke says that a black fox has been seen several times the past few years in the La Sal mountains.

Mr. F. A. Wrathall informs me that about eighteen years ago he received two black fox skins and eight cross foxes from some trappers who had been working at the head of the Duchesne river. The black skins were dressed and sold to a New York tourist for $\$ 400$ each. He reports the cross fox as not at all uncommon, and the red fox affords a constant supply. He has almost every color gradation in his possession, all taken from Utah.

Habits-Their bill of fare includes many items, as mice, birds, reptiles, insects, many kinds of fruits, and on rare occasions a chicken. The bad name borne by them 
among farmers, due to occasional raids on the poultry yard, is largely unwarranted. They kill enormous numbers of mice and other small rodents each year, and thus well repay the loss of a chicken now and then. Red foxes apparently pair for life and occupy dens dug by themselves in a secluded knoll or among rocks. These dens, which are sometimes occupied for years in succession, always have two or more entrances opening in opposite directions, so that an enemy entering on one side may be readily eluded. The young, numbering up to eight or nine, are tenderly cared for by both parents. (Nelson.)

The prices at present paid by the raw fur dealers of St. Louis for fox are as follows: Black fox, $\$ 800.00$ each for extra large and fine pelts; $\$ 500.00$ each for large; $\$ 350.00$ each for medium; $\$ 200.00$ each for small, and as low as $\$ 10.00$ for damaged or inferior skins. Silver fox, $\$ 550.00$ each for extra large and fine; $\$ 400.00$ for large; $\$ 275.00$ for medium; $\$ 175.00$ for small, and as low as $\$ 7.50$ for damaged and inferior skins. Cross fox (dark), $\$ 150.00$ for extra large and fine; $\$ 110.00$ for large; $\$ 70.00$ each for medium; $\$ 40.00$ each for small, and as low as $\$ 3.00$ each for damaged or worn skins. The pale cross fox pelts range in price from $\$ 75.00$ each down to $\$ 1.50$.

\title{
SCOTT'S GRAY FOX
}

\section{UROCYON CINEREO-ARGENTEUS SCOTTI (Mearns)}

\author{
Urocyon cinereo-argenteus scotti Mearns, Bull. Am. Mus. \\ Nat. Hist. N. Y., 1891, p. 236.
}

Description-Color above grizzled gray, many of the hairs black-tipped, especially along the middle of the back; upper half of back of ears gray, lower fulvous; chin and side of upper jaw black, except white spot at tip of latter; throat and belly white, bordered by fulvous and an indefinite patch or band of same; front of forelegs gray, back fulvous; tail above gray with prominent black stripe, below fulvous. Length 39.4 inches; tail, vert., 16.2 inches; hind foot, 5.5 inches. (Warren.)

Distribution-A few specimens of the gray fox have been taken in Garfield County, Utah; and B. E. Mattsson reports that several have been trapped along the summit of the Manti forest. J. W. Humphrey says that the trappers of the Biological Survey have frequently trapped them 
in the lava country near Panguitch. A. W. Jensen has found them in the Uintah forest. This fox is found in Arizona, New Mexico, Texas, Oklahoma, Colorado, and and Chihuahua, Mexico. Like other foxes, it lives on wood rats, rabbits, mice, and other small mammals and birds.

Mr. F. A. Wrathall has dressed several skins of this species, sent him from Iron county. S. B. Locke says that they are well distributed over the La Sal national forest.

Habits-Gray foxes do not regularly dig a den, but occupy a hollow tree or cavity in the rocks, where they bring forth from three to five young each year. As with other foxes, the young are born blind and helpless, and are also almost blackish in color, entirely unlike the adults. The parents, as usual with all members of the dog family, are devoted to their young and care for them with the utmost solicitude. Like other members of the tribe, they are omniverous and feed upon mice, squirrels, rabbits, birds, and large insects, in addition to acorns or other nuts and fruits of all kinds. (Nelson.)

\section{KIT FOX: SWIFT}

\section{VULPES VELOX (Say)}

Canis velox Say, Long's Exped. Rocky Mts., 1, 1823, p. 487. Canis vinereo-argentatus Sabin, Frankl. Narr. Journ. Polar Sea, 1823 , p. 658 .

Canis microtus Reichenb., Wagn. in Weigm. Archiv. III, 1837, II, p. 162.

Vulpes velox Elliot, Syn. N. Am. Mamm. F. C. M. Pub., II, 1901 , p. 306.

Description-This small fox is considerably less in size than the red or gray fox. The fur is remarkably full and dense, much more so than in the red fox, and the interspersed longer hairs exceed in length the under fur so little as to permit it to be readily seen. The limbs are rather short but stout, the feet shorter and the body lower than in the red fox. The tail is rather short in its proportions, scarcely more than half as long as the head and body. It is, however, remarkably dense and bushy, being made up principally of under fur, instead of having its contour determined by the long hairs. There are no strongly marked contrasts of color in this diminutive fox. The entire upper parts and sides, extending low down on the thighs and shoulders, are conspicuously grizzled with pale grayish 
white and brownish yellow, mixed with a little dark brown or black. The under fur in these regions is light plumbeous at base, and light brownish chocolate yellow at tip, these tints becoming paler towards the sides. The long stiffer hairs are dark brown (more reddish at the extreme tip) and broadly annulated near the tip with yellowish gray white; there is, however, an occasional hair that is entirely black. The under fur on the top of the head has more reddish on the terminal portion. The under parts generally, for their entire width, as well as the inside of the limbs, are yellowish white. On the sides of the neck and body, extending some distance up behind the shoulders, the hairs are of a pale reddish yellow, without annulation, this color also tinging strongly the forearm and posterior face of the hind leg; the rest of the legs, except as described, is of a pale brownish white. There is a dusky tinge around the lips, and a patch of the same between the eye and the nose, above the insertion of the whiskers, which are themselves black. The ears are uniform brownish yellow on their convexity; anteriorly yellowish white. The tail, in general tint, resembles the back, except that there is no distnict annulation the prevailing hue being a yellowish gray. There is a considerable amount of black on the tips of the hairs, but this is much less conspicuous than in the red and gray foxes. There is most black at the truncate tip. The under surface of the tail is tinged with yellowish red. Length from nose to tail 24 inches; from tail to end of vertebrae 9 inches; height of ear above notch $1 \frac{3 / 4}{4}$ inches. (Baird.) In summer specimens the fur is shorter on all parts of the body and the feet are thinly haired.

Distribution-Several years ago a kit fox was killed at the New State Gun Club in Davis county a few miles north of Salt Lake City, Utah, and Mr. F. A. Wrathall, who dressed the skin, informs me that he receives the kit fox continually from nearly all parts of northern Utah. He has a fine skin, taken at Wendover, in the western part of the state. This fox is not at all uncommon so far as foxes go in this state. Gerald Thorne tells me that this fox is frequently trapped in the Uinta basin; and he has one in his possession which was taken at Jensen, Utah, in 1908.

Habits-The swift fox is the smallest and daintiest of all our foxes. Owing to the readiness with which it eats poisoned meat that has been put out for wolves, it has already become very scarce. In spite of its name, it does not run with remarkable swiftness. (Hornaday.) 


\section{Family URSIDAE, Bears \\ Subfamily URSINAE}

\section{UTAH GRIZZLY}

\section{URSUS UTAHENSIS (Merriam)}

Ursus utahensis Merriam, Proc. Biol. Soc. Wash., XXVII, pp. 193-194, 1914.

Description-Size large; coloration apparently normal. Skull long, narrow, and high, but not arched; fronto-nasal region high and very narrow-strongly pinched in. ColorSkin of male on Pine Valley Mountain, southwest Utah (obtained from forest ranger, September 24, 1907, by Clarence Birdseye) Muzzle pale brown; face and throat, except pale lip edgings and long hairs of median line of throat, dark brown, becoming grizzled posteriorly; top of head very dark; grizzled posteriorly by brown-tipped hairs. Cranial characters: Adult male (type and equally old male from northeast corner Sevier National Forest) Size large; skull very long, high, and exceedingly narrow; zygomata moderately spreading and outbowed; frontal shield narrow, flattened posteriorly, falling away laterally immediately in front of orbits, leaving a high fronto-nasal ridge; short pointed posteriorly; sagittal crest long and high, reaching anteriorly nearly to mid way between fronto-parietal suture and plane of postorbital processes; postorbital processes very long, slender, peglike, and horizontally extended; rostrum long, high, rather narrow, and strongly compressed below nasals; palate and postpalatal shelf exceedingly long; postpalatal shelf and notch narrow; interpterygoid fossa exceptionally deep; basisphenoid strongly concave. Under jaw very long, ramus flat and exceedingly broad vertically; large coronoid blade high and moderately recurved. Dentition light for so large a skull; canines rather small; upper and lower molariform series medium or rather small; middle lower molar decidedly narrow. (Merriam.)

Distribution-The type locality of this species is the North Fork of Salina Creek, ten or twelve miles southeast of Mayfield, Utah, where the type specimen was collected May 22, 1911, by Mart Martenson. The range of this grizzly includes the southern Wasatch and all of the Pine Valley mountains though the further limits are unknown. 


\section{BAIRD GRIZZLY}

\section{URSUS HORRIBILIS BAIRDI (Merriam)}

Ursus bairdi Merriam, Proc. Biol. Soc. Wash. XXVII, pp 192193, 1914.

Ursus horribilis bairdi Merriam, N. A. Fauna, No. 41, p. 19, 1918.

Description-Size large-in the Rocky mountain region exceeded only, if at all, by horribilis ; skull long, with narrow elevated fronto-nasal region; claws of moderate length, smooth. Cranial characters-Old male (type) from Blue River, Colorado. Size large; fronto-nasal region high and rather narrow; rostrum rather long, narrow and strongly compressed in front of orbits; face long sloping; frontal shield flat, short pointed, faintly depressed medially; shield and nasals in essentially same plane except that anterior third of nasals is slightly upturned; postorbital processes large, outstanding, flat, and blunt; orbital rims prominent; sagittal crest moderately high posteriorly; temporal impression shorts, incurved, beaded; zygomata strongly outbowed, squarely spreading posteriorly; lachrymal duct notching orbital rim; squamosal shelf front, arched over meatus, the free edge thickened; palate and postpalatal shelf of moderate breadth; mastoids rather long, divergent. (Merriam.)

Distribution-Southern Rocky Mountain region from San' Juan mountains, southwestern Colorado, northward through Wyoming to Montana, and perhaps to southeastern British Columbia.

In July, 1918, Dr. Merriam wrote me as follows: "The grizzly of the Wasatch mountains is still open to question, but a not fully adult male killed in the Uintas by Vernon Bailey some years ago appears to be Ursus Bairdi. There is a skull of an adult male grizzly of the planiceps group in the Utah Museum, but no one seems to know where the animal was killed. It is possible of course that the two species occured in the Wasatch."

For some years Dr. Merriam has been working on the grizzly and big brown bears of North America, accumulating for comparison during that time at Washington a collection of bear skulls that far excell all other collections in the world together. Thus far he has separated the grizzly and brown bears into 98 forms and has added one new genus. There is a great need for specimens from Utah, Idaho, Wyoming and Colorado; and until further material is furnished full determinations cannot be made. It mav 
be said, however, that some of the brown bears, which for years were regarded as merely color phases of the black bear, may have been grizzlies; though few hunters mistake a grizzly when he sees one. The terrible claws of the adult grizzly at once distinguish him from the black bear. It is unfortunate that at this time merely the technical descriptions can be given; but Dr. Merriam has based his classification chiefly on cranial characters, which are probably the most reliable points of difference.

The grizzly bear is not nearly so uncommon in Utah as one would naturally suppose from reports of the general scarcity of the animal in the West. Several have been killed in recent years on the Aquarius Plateau and in the Panguitch mountains, Garfield county. B. E. Mattsson of Ephraim says that eight grizzlies have been killed in the Manti forest in the past seven years. J. W. Humphrey of Panguitch reports that grizzlies are found occasionally in that section. In March, 1916, R. Jolley and C. Riddle of Coyote, Utah, killed a grizzly of enormous size; it was estimated that for several seasons this bear had killed over fifty cattle a year in Garfield county. E. C. Shepard of Logan says that ten or twelve grizzlies are known to inhabit the rugged portion of the Ashley forest. A few years ago grizzlies were not uncommon in the Fish Lake district, but now they have been almost exterminated, according to C. A. Mattsson of Salina. George H. Barney of Escalante reports that twelve or fifteen grizzlies have been killed in the Escalante forest during the past few years. A. W. Jensen reports that a few still exist in the Uinta mountains. A few years ago grizzlies were trapped every season in Hardscrabble Canyon, about fifteen miles east of Salt Lake City, by Dan Bodily of Kaysville, while John Burton of Kaysville, Utah, has killed several in the same vicinity. At the State Capitol is a small mounted grizzly that was taken from the vicinity of Coalville in 1920 .

Habts-Ferocious, quick-tempered, and incredibly powerful, the grizzly bear is without doubt the most dangerous animal in America; in fact, excepting possibly the reckless rhinoceros of Africa, it is more defiant than any other wild beast of the world. Man, however, is fast wearing the animal's spirit down; and one must seek the remotest wilds to find the real, terrible grizzly of early days.

From the earliest date this great bear has entered somewhat into the frontier history of the country. The Indians held it in awe and reverence, never venturing to hunt it alone. In fact, when in search of it, they invariably 
went in parties of from twenty to thirty, each hunter armed with a long spear. Upon sighting the grizzly licking its paws they would approach quite closely and form a double line away from it. One Indian would then disturb the bear, and, upon being chased, run down between the rows of men, who, in turn, would spear it as it chased between them.

Roosevelt says that the word "grizzly" does not refer to the color of the animal, but should be spelled "grisly," meaning terrifying or horrible. He, however, cites no authority for his statement.

In the early days the grizzly bear preyed upon the buffalo; but now it is found only in the wildest mountains. The old hunter had only a single barreled rifle, and had to make the one shot count. One bullet will not, however, usually stop a grizzly; in fact, one was once shot eight times through the head and twice through the heart, yet it swam half a mile thereafter and survived twenty minutes! The grizzly cubs sometimes climb trees but a full grown grizzly cannot climb.

The modern rifle has been too much for the grizzly, which, today, except in the very wildest regions, shuns man and seeks safety in seclusion. Cornered, however, he is as indomitable and ferocious as ever, fighting with his ghastly teeth and massive ripping claws as long as a breath of life is in him. Hornaday says that a wounded grizzly usually runs down hill and that this accounts for some charges towards the hunter below, which might not have taken place had the hunter been to one side.

So powerful is the grizzly that in the bull rings of early California, one bear has been known to kill six bulls in an afternoon. The maddened bear would rise upon its hind legs as the bellowing bull with lowered head would come upon him; and then, at a favorable moment, the bear would strike the bull dead with a blow between the eyes.

During may the grizzly eats snow lilies, roots and grass; in June and July, ants and edible roots; in August, berries such as strawberries and service berries; in September, huckleberries, blue berries and black currants as well as wild pea vines; and in October, gophers and Hedysarum roots. At times, however, it eats cattle, deer, elk, wild plums, mast, honey, fish, pigs, carrion, and, according to Hornaday, one of its own kind if it finds it dead.

Grizzly bears are gregarious, that is, they roam frequently in numbers together. Indians say that they sometimes found a grizzly bear killed by a mountain lion but never a mountain lion killed by a grizzly. 
The grizzly's cubs, usually two, almost hairless and poorly formed, are born in the winter den in the middle of January. They are ten inches long, 18 ounces in weight and blind as well as helpless. The period of gestation is about 266 days-from April 22 to January 13.

The strength of a grizzly is shown by the fact that one carried the carcass of a heifer for fifteen miles and as fast as most men can run. Others have been seen to carry a full grown pig in its forearms and mouth as easily as a boy would carry a cat.

\section{BLACK BEAR}

\section{URSUS AMERICANUS (Pallas)}

Ursus americanus Pallas, Spicileg. Zool., fasc. XIV, 1780, p. 5.

Description-The typical black bear of eastern America is deep, glossy black everywhere, excepting the muzzle, which is more or less brown, and the white spot sometimes seen on the breast. As one nears the Mississippi various shades of cinnamon brown are found, and in the Rocky mountains fully a quarter of the bears are of the cinnamon variety. This difference of color, however, does not mean a difference of species; they are mere freaks or sports of the black race. A black bear may have cinnamon young this year and black the next, or even one of each kind in the same litter. So also a cinnamon mother may give birth to either black or cinnamon young. (Seton.) Female of average size: Snout to tail tip, 63.5 inches; tail 5 ; hind foot, 7.25 ; height at shoulders, 25.5; weight, $2271 / 2$ pounds. Black bears readily climb trees; but grizzlies cannot.

Distribution-Clinton Milne informs me that there are but few black bears in the St. George district, though several are killed from time to time. Milton Moody killed one in Pine Valley mountains a few years ago, which had covered three mountain ranges and killed many cattle and sheep. B. E. Mattsson of Ephraim reports that seventyseven black bears have been killed in the Manti forest during the past seven years; very few remain there. J. W. Humphrey of Panguitch says that a few are found in the inaccessible places of the Sevier forest and are not numerous enough to be a menace to livestock.

Black Bears are, however, fairly plentiful in the Vernal country, according to William M. Anderson; and twenty 
or thirty are left in the Escalante forest where they range principally to the south and east. A. W. Jensen estimates that fifty or more exist in the Uintah forest while E. C. Shepard says there are about a hundred in Cache national forest. I have found them at the head of City Creek canyon only a dozen miles from Salt Lake City; and in 1917 a hunter took seven out of the canyon just above Bountiful, Davis County, Utah. I have also encountered them on the mountains above Richmond, Cache County. They are quite plentiful in Hardscrabble canyon just over the divide from the head of City Creek Canyon above Salt Lake City. In 1916 bounty was paid on 146 bears killed in the following counties: Cache 7, Carbon 21, Duchesne 18, Emery 4, Juab 2, Morgan 4, Summit 17, Uintah 14, Utah 29, Wasatch 15 and Weber 4. In 1915, 193 were killed as follows: Box Elder 1, Cache 18, Carbon 6, Davis 2, Emery 7, Garfield 8, Grand 7, Morgan 18, Rich 6, Salt Lake 3, San Pete 25, Summit 11, Uintah 15, Utah 21, Wasatch 28, Wayne 8, Weber 9.

A mammoth black bear was killed near Heber City several years ago by Isaac McDonald. It is said to have weighed nearly 800 pounds; and Mr. F. A. Wrathall of Salt Lake City, who dressed the skin, found it to be larger than any grizzly pelt he had ever worked on.

S. B. Locke says that black bears occur at the head of Pack Creek, Mill Creek and Castle Creek in La Sal national forest; around Shay mountain and at the head of North Cottonwood Creek in the Blue mountains. Several are killed there every year.

Black bear skins bring the hunter from $\$ 1.50$ to $\$ 35.00$ each; the brown skins, from $\$ 1.00$ to $\$ 28.00$ each, and the cubs, from $\$ 1.00$ to $\$ 20.00$ each.

Family PROCYONIDAE, Racoons, Coatis, etc. Subfamily PROCYONINAE

\section{RACOON-FOX: RING-TAIL: CIVET FOX}

\section{BASSARISCUS ASTUTUS (Lichtenstein)}

Bassaris astuta Licht., Isis, 1831, p. 513.

Bassariscus astutus Elliot, Syn. N. Am. Mamm. F. C. M. P. II, 1901, p. 316.

Description-Body slender, elongate; muzzle pointed, tail long, bushy; claws half retractile; skull long, slender; postorbital process of frontal bone short; upper sectorial with inner cusp much developed; anterior cusp of lower 


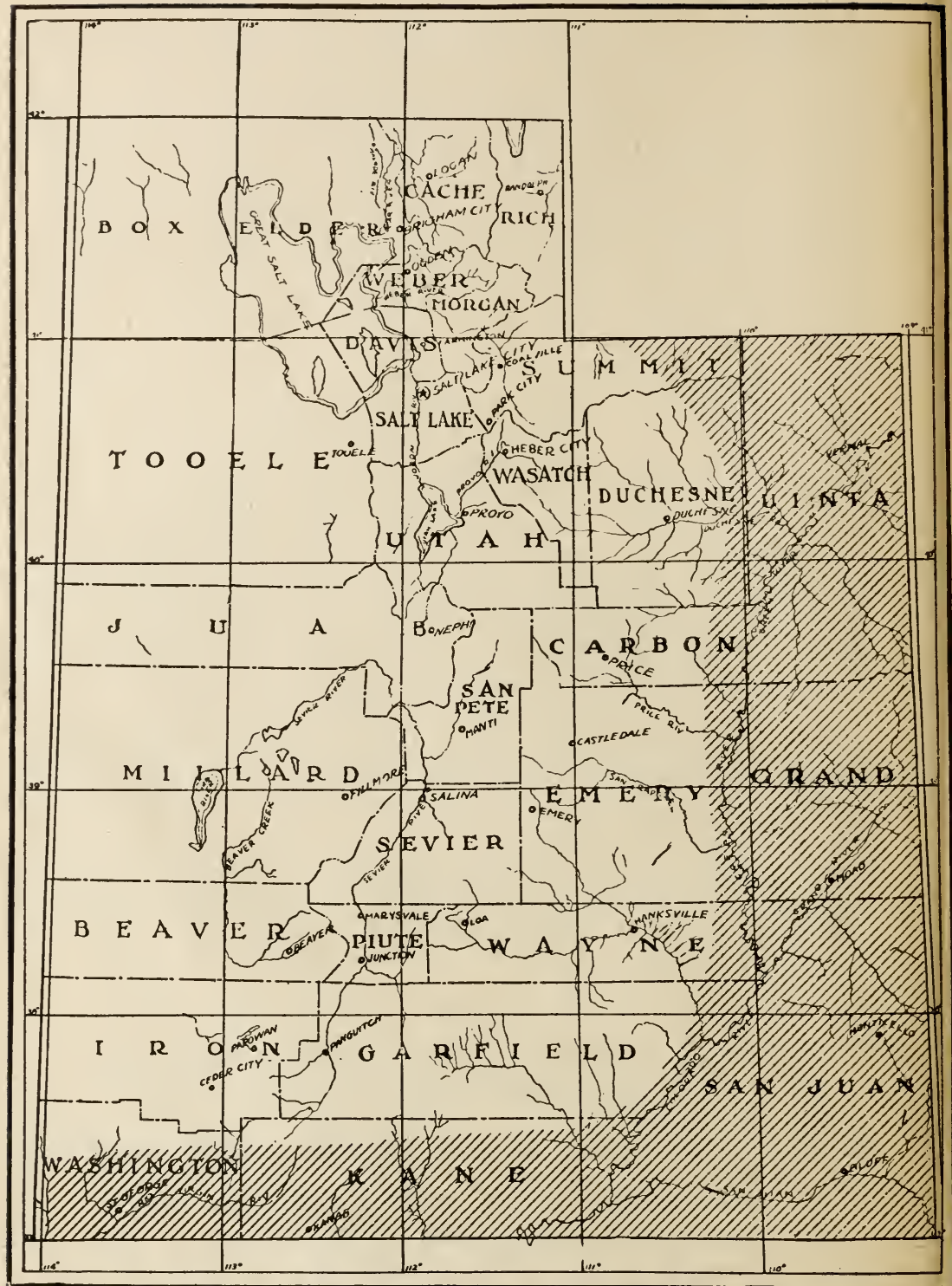

Map No. 24.-Range of the Raccoon (PROCYON LOTOR MEXICANUs Baird) in Utah. Based on records by Claude T. Barnes. 
sectorial shortest. Above yellowish brown and gray mixed; below white. Legs and feet like the body. Tail, white with six or eight alternate black rings. (Elliot.) Total length 28 inches; tail vert., 13 ; hind foot 2.3. (Warren.)

Distribution-California, Arizona, southern Utah, New Mexico, Colorado, Texas. Several years ago Andrew Holman killed a ring-tail near Vernal; and this is the only actual record I have of its occurrence in this state. Nelson includes southern Utah in his description of the range of this species. Several have been taken in adjacent portions of Colorado. S. B. Locke, however, informs me that they occur in the La Sal national forest, prefering low elevations.

Habits-The ring-tail is known as "civet cat," "coon cat," "band-tail cat," "cacomixtle" (in Mexico), and "babisuri" (in Lower California). It is about the size of a large cat, but with proportionately longer and slenderer body, shorter legs, and longer tail. The alternating bands of black and white on the tail proclaim its relationship, not to the cat, to which it has no kindship, but to the racoon, which has a tail similarly marked. Few mammals possess such a beautifully formed head and face, and its large mild eyes give it a vivid expression of intelligence. While chiefly rock-inhabiting species, they sometimes live in the forest and as a rule make their dens in caves and deep crevices, but sometimes in hollow trees or about houses. Their young, from three to four in number, are born in May or June. Like its relative, the racoon, the ring-tail takes whatever edibles come its way. Its fare includes wood rats, bats, birds, chickens, insects of many kinds, larvae, centipedes, fruits (pear leaved cactus among others), green corn. They are nocturnal and their visitation is detected usually by the cat-like trails they leave. (Nelson.)

\section{RACCOON}

\section{PROCYON LOTOR MEXICANUS (Baird)}

Description-The word "racoon" is derived from the Indian word "arocoun" by which this animal was known in Virginia. The racoons have on each foot five well developed toes with claws, the soles naked, the hind feet plantigrade; they have pointed nose and ears; tail, rather long and bushy, usually ringed. A male weighs about 18 pounds, a female 10 pounds. A typical Procyon lotor is described as follows: In general a dull brownish gray, becoming yellower on the 
back, strongly yellow on nape and on tail, and a paler gray on the belly and feet; on all the upper parts, especially along the spine, the long hairs are black-tipped, and on the under parts, they are white-tipped. On the cheek is a black patch that includes the eye, and joins with the narrow blackish stripe that runs from the nose to the dark color on the forehead. Around this the face is dull white, whitest in a band above each eye; the lower back part of the ear is black, which joins with a black patch on the neck behind the ear-the tip of the ear behind is whitish. The tail, beginning with the tip, has six to seven rings of very dark brown or black on a pale yellowish background. The under fur is dark brownish gray and shows much on the under parts; the throat also is dark brownish gray; the eyes are dark; the whiskers white. The sexes are alike. Mexicanus is a large, pale gray race with long tail. (Seton.)

Distribution-This racoon ranges northward from the Gulf of Mexico through New Mexico, the eastern half of Arizona and into Utah. A few racoons are known to inhabit the swamps, fields and streams near St. George, Utah. According to Clinton Milne many are trapped there each year, their pelts bringing an average of $\$ 1.75$ each. $\mathrm{He}$ states that they are very fond of grapes, which are extensively grown in that vicinity. Gerald Thorne of Logan informs me that Peter Miller of Linwood, Utah, trapped a racoon on the bank of Henry's Fork just below the Wyoming line. Mr. Thorne had the skin in his possession just after it was taken in the autumn of 1912 . S. B. Locke reports that racoons appear occasionally along the streams of southeastern Utah.

Habits-They everywhere seek the wooded shores of streams and lakes and the bordering lowland forests, and are expert climbers, commonly having their dens in hollow trees, often in cavities high above the ground. In such retreats they have annually from four to six young, which continue to frequent this retreat until well grown, thus accounting for the numbers often seen in the same cavity. Their diet is extraordinarily varied, and includes fresh water clams, crayfish, frogs, birds and their eggs, poultry, nuts, fruits, and green corn. When near water they have a curious and unique habit of washing their food before eating it. They make good pets. (Nelson.)

Racoon skins bring the trapper from 25 cents to $\$ 9.00$ each at St. Louis. 
Family MUSTELIDAE, Badgers, Weasels, Otters, etc. Subfamily MELINAE

\section{BADGER}

\section{TAXIDEA TAXUS (Schreber)}

Ursus taxus Schreb., Saugth., III, 1778, p. 520.

Meles taxus var B. americanus Bodd., Elench., Anim., 1, 1785, p. 136 .

Ursus labradoria Geml., Syst. Nat. 1, 1788, p. 102.

Meles jeffersoni Harl., Faun. Am., 1825, p. 309.

Taxidea americana Elliot, Syn. N. Am. Mamm., F. C. M. Pub. II, 1901, p. 320.

Description-The genus Taxidea comprises large animals of the weasel family (Mustelidae). They have thick, heavy bodies, very short tails, short legs, front feet immensely powerful, with long claws and developed for digging; ears, very short. Length, about 28 inches; tail, 5 inches. Weight 10 to 23 pounds. General color above, silver gray, each hair being yellowish white at base, then blackish with a white tip; neck, crown and muzzle above, brown; cheeks, chin and stripe from nose over head to shoulders, white; under parts generally yellowish-white; bar on each cheek, back part of ear, and the feet, dull black; tail, tinged yellowish brown. When seen alive it looks like a small bear that has been flattened somehow, colored silvery gray, and adorned with black and white marks on the head. (Seton.)

Distribution-The badger is found throughout the State of Utah. A few are seen in the St. George district but they are there decreasing. They are quite common on the Manti forest, very common in the Cache forest, fairly numerous in the Panguitch region and not very common in the Ashley forest. They are quite numerous about Salina and on the mountain ranges up to 8,000 feet. They are found throughout the Escalante forest, the Uintah forest, and are seen so often in Tooele county that efforts are being made by those ignorant of their worth, to exterminate them on account of their undermining telephone poles. They are quite common within the city limits of Salt Lake City, their burrows appearing in the adjacent canyons and on the flats west of the city.

Habits-No animal better deserves the protection of the farmer than does the badger. It lives principally on prairie dogs, ground squirrels and other harmful rodents. How any one acquainted with this animal's habits should 
desire to kill it, is beyond comprehension; yet some farmers will actually shoot badgers and at the same time complain that they will have to give up their farms if something is not done with the ground squirrels.

Mr. J. R. Stringham of Holden, Utah, has written me some very interesting facts concerning the badger. $\mathrm{He}$ says: "I saw in June, 1092, a badger walking with her young, twelve miles northwest of Holden. I tried to capture her, but she put up such a fight that I could not, and the young ones got into a hole about twenty-five yards away. Two years ago I caught a very young one in the timber country at the head of Snake Creek canyon on the southeast of Jeff Davis mountain, near Baker, Nevada. It was much less than a year old. Two years ago I followed the tracks of a badger in the snow and found where it had had a fight with two large coyotes. The snow was about sixteen inches deep, and the battle had been long and fierce, the badger apparently being the winner for he had retreated to his den, about two miles distant, without the loss of blood, while the coyotes had lost blood and had made but short distances between the places where they had stopped to lick their wounds and to rest. This winter has been very well supplied with snow yet we have caught a badger a day, when the sun has come out. Their dens run straight into the side of the wash about four feet, and, apparently have two openings, as the tracks lead from one to the other, a distance of about one hundred feet. Their dens cannot be detected by fresh diggings in the winter, as they never step in the snow if they can help it. On the sixth of January we found a den where the badgers had been traveling all around in the deep snow. We followed one for nearly a mile. I have known of persons having badgers as pets."

Badger skins are worth from 10 cents to $\$ 5.00$ each according to size and condition.

\section{GREAT BASIN SKUNK \\ MEPHITIS OCCIDENTALIS MAJOR (Howell)}

Chincha occidentalis major Howell, N. Am. Faun. No. 20, 1901, p. 37.

Description-Color: Much as in occidentalis; white stripes broad, bifurcating near the middle of the back, and extending only a short distance on the tail, which is nearly all black exteriorly. 
Distribution-Eastern Oregon, northern California, and Nevada; east to the Wasatch mountains in Utah. Specimens have been taken at Ogden and at Provo.

Habits-Sorne animals protect themselves with sheer strength, assisted by teeth and claws, some emit poisons and some resort to flight, but excluding the spiny armament of the porcupine probably no defense is so immediately effective as the fetid odor thrown out by a threatened skunk. It forfends the enemy as surely as the Aegis of Minerva, for days and even weeks of foulness and smart repay the unwise aggressor for his unprovoked attack.

The favorite environ of the skunk is the edge of woods and marshes, where abundant food, warmth and shelter can be found in the varied sunlight and shade. Its range of activity is very small, seldom exceeding a radius of half a mile.

Mating in March, the skunk, which is monogamous, digs its den in a dry place on a hillside, or selects an abandoned badger, muskrat, or ground squirrel burrow. Towards the end of April four to ten young are born, each the size of a mouse, naked, and for a few days both deaf and blind. Hairless as they are even at that time the white strips reveals their identity. When a month old they are capable of emitting the loathsome musk.

The food of the skunk consists of grasshoppers, crickets, insects, mice, ground 'squirrels, frogs, eggs, rabbits, and berries. Its enemies are few, the owls probably being most feared.

Skunk skins are worth from 25 cents to $\$ 12.00$ each.

\title{
ROCK SPOTTED SKUNK
}

\section{SPILOGALE GRACILIS SAXATILIS (Merriam)}

\author{
Spilogale saxatilis Merriam, N. A. F. No. 4, 1890, p. 13.
}

Description-Size, rather large; tail, with hairs, longer than head and body. External lateral stripes nearly obsolete and barely or not continuous with anterior transverse stripes. In the type specimen, an adult male, none of the markings are confluent. In an old female taken at the same locality and date, the internal or middle dorsal stripes are narrowly confluent posteriorly with the anterior transserse stripes, and the caudal spots meet indistinctly across the base of the tail. All of the other spots and markings 


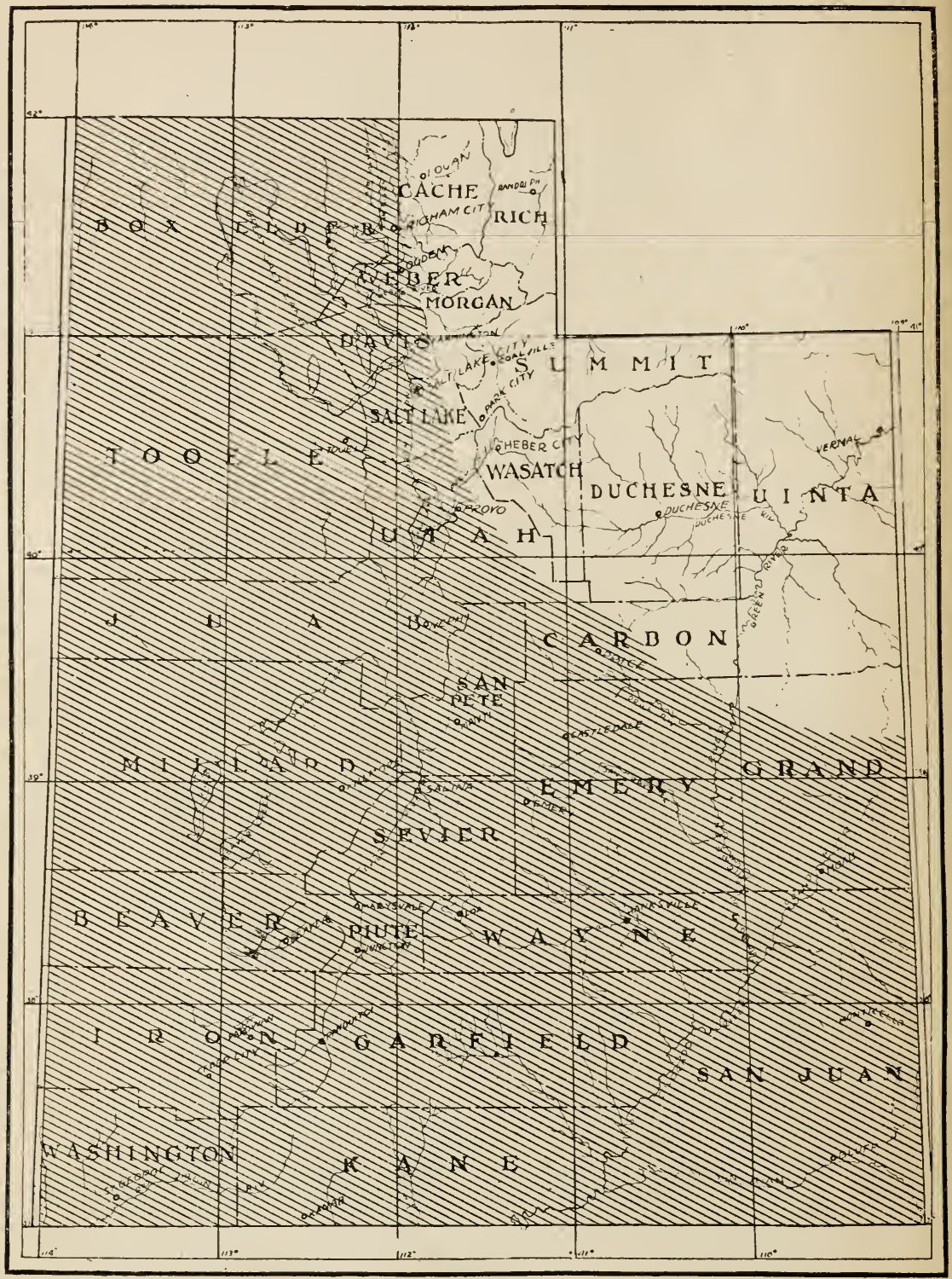

Map No. 25.-Range of the Rock Spotted Skunk (SPILOGALE GRACILIS SAXATALIS Merriam) in Utah. Based on the map of A. H. Howell. 
are distinct. Externally S. saxatilis may be distinguished at a glance from its nearest geographical neighbor, S. gracilis, by the inconspicuous and nearly obsolete lateral stripe. In $\mathbf{S}$. gracilis this stripe is large and broad and broadly confluent with the anterior transverse stripe. (Merriam.)

Distribution-Utah, western Colorado, northern Nevada, southern Idaho, eastern Oregon, and northeastern California. The type locality of this species is Provo, Utah, though several specimens have been taken at St. George, and Professor Jones informs me that he has taken it at Marysvale. S. B. Locke says it is rare in southeastern Utah.

Habits-The little spotted skunk, being more agile than the larger members of the genis Mephitis, frequently climb bushes. They prefer rocky situations, making their homes in rock piles, cliff crevices, hollow logs, deserted burrows, or bushy river bottoms. Some live beneath farm buildings. They often dig small holes in search of insects. They are strictly nocturnal, being seldom seen except on moonlight nights, when their markings so blend with the lights and shadows as to render them inconspicuous. Their bite seldom produces ill effect. Their food consists of insects (mostly beetles and grasshoppers), mice, lizards, salamanders, small birds, crawfish, fungi, hen's eggs, wood rats, house rats, and rarely squirrels. They do more good than harm.

\section{WOLVERINE: SKUNKBEAR: GLUTTON: CARCAJOU}

\section{GULO LUSCUS (Linnaeus)}

Mustela gulo Linn.. Syst. Nat. I, p. 45, 1758.

Ursus luscus Linn. Syst. Nat. I, p. 47, 1758.

Gulo luscus Elliot, Syn. N. Am. Mamm. F. C. M. Pub. II, 1901, p. 333. Zool. Ser.

Description-General colour a deep blackish-brown, paler and grayer on crown and cheeks; a band of pale chestnut begins on each shoulder and passes backwards along the sides to meet its fellow on the tail; these become nearly white on the rump in some specimens; the throat and chest are more or less spotted with yellowish-white, which sometimes forms a large irregular patch; claws, whitish horn. 


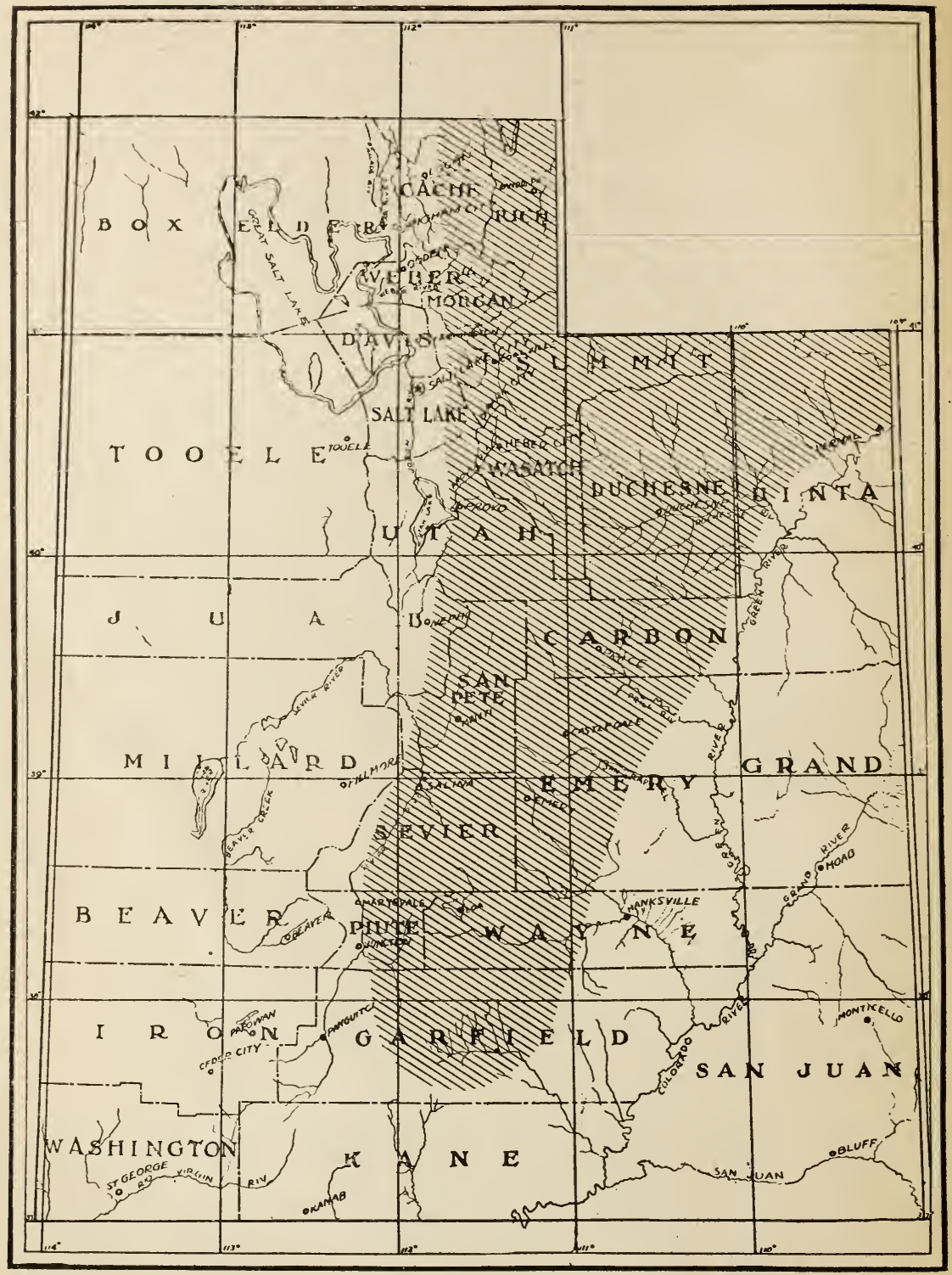

Map No. 26.-Range of the Wolverine (GULO LUSCUS Linn.) in Utah. Based on E. T. Seton's map and records by Claude T. Barnes. 
colour. Sexes alike. (Seton.) The name "Skunkbear" is commonly used in describing this species in the Rocky Mountain region, because in size, color and shape it resembles a cross between a skunk and a black bear.

Distribution-Boreal North America from the Atlantic to Alaska, south to central and southern Utah.

Brigham Spencer of Moab, Utah, informs me that in 1893 he encountered two adult and two young wolverines on Boulder Mountains, Garfield County, Utah. The animals showed fight to such an extent that he succeeded in procuring only one of the four. The last time he saw wolverines in Garfield county was in 1897. Theodore Suholser of Logan says that several wolverines have been trapped there, and that there are some yet on the high timber range from Idaho towards the Uintah mountains. He adds: "The wolverines can raise more hell when caught in a trap than any other animal three times its size. It is the strongest and meanest animal of its size."

Habits-Despiteful, greedy, almost uncanny in its diabolical hindrance of the trapper, the wolverine is unquestionably one of the most annoying and fierce animals of the woods. In fact John Burton informs me that there is no animal, not even the grizzly, that he would not as soon meet face to face as a female wolverine with her young.

The individual range and endurance of a wolverine are apparent from the fact that one has been known to carry a heavy trap for six miles. Trappers say that it will sneak after them for sixty miles to steal bait. Each one roams over a territory fifty miles square in winter; but in summer this is much restricted.

Near the end of March the species pair, the male afterwards probably assisting with the young. A large nest of dried leaves is usually made in a cavern already used as a winter refuge. The place is quite clean, as wolverines neither store food nor leave garbage in their dens. The young, however, may be born in some sheltered hollow or in a hole dug under a big rock by the mother.

Parturition, following a gestation of sixty days duration, occurs in June from two to five being born. The young are suckled for eight weeks and fed at home. until October, after which the whole family hunt together.

A wolverine rarely climbs, seldom attacks a grown deer and eats what appeals to other carnivora of the same size. By constant gnawing, even after its mouth bleeds, a wolverine will sever a log a foot in diameter and so cleverly make the cut that the log will fall so as to leave an open- 


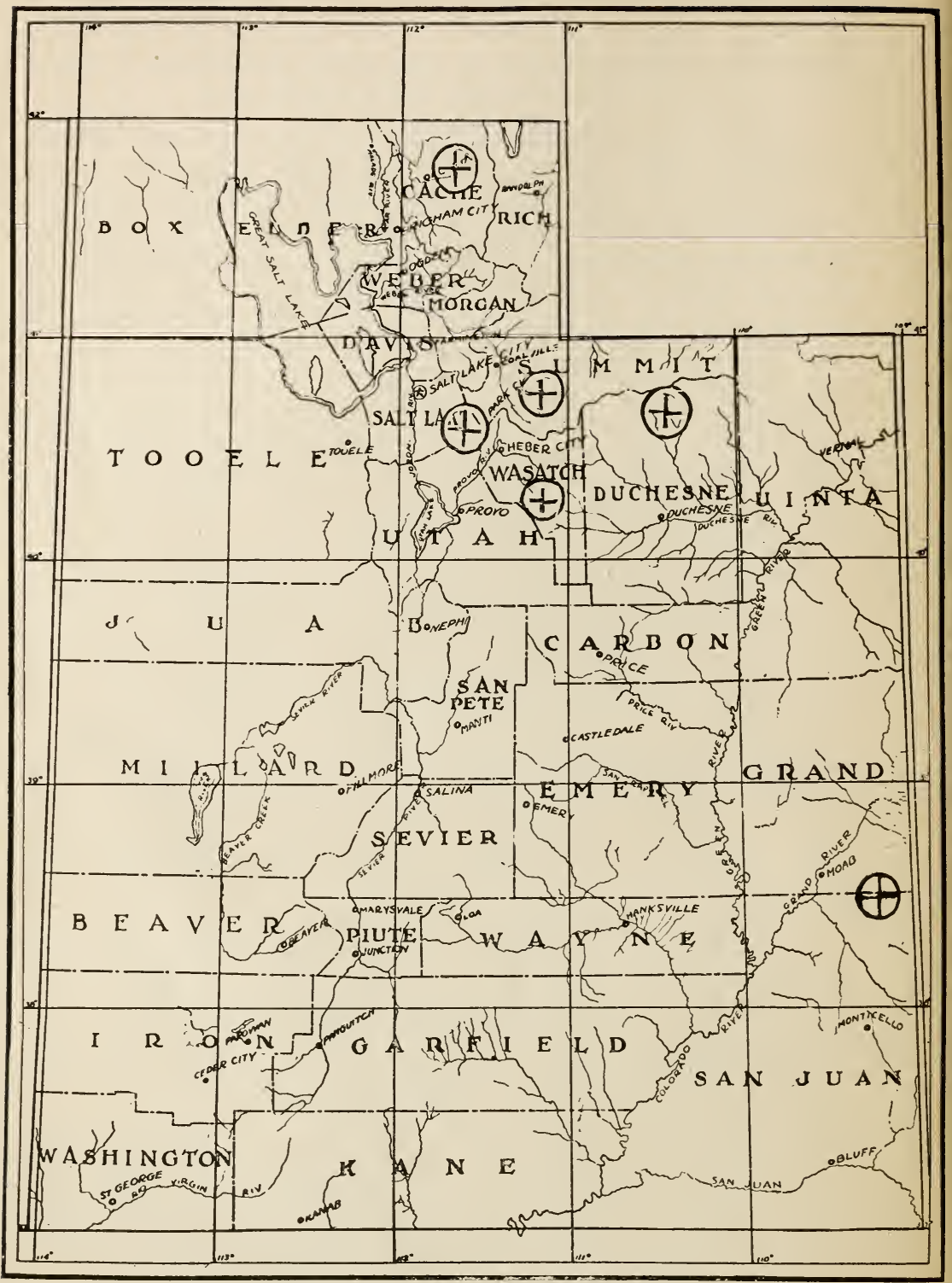

Map No. 27.-Distribution of Rocky Mountain Marten (MUSTELA CAURINA ORINGENES Rhoads) in Utah. Based on records by Claude T. Barnes. 
ing. All the meat it can find it carries away and smears it with a fetid glandular secretion loathsome to other animals. So many tracks are made in the snow that its caches are almost imperceptible; and in fact a fox is about the only animal with the taste to ferret out the stinking meat.

Wolverines are almost uncanny in their actions at times. A set gun was placed for one once; the wolverine appeared, bit the string in two just behind the gun muzzle and carried the bait away. Three times this was repeated by the trapper; and each time the wolverine bit the string just behind the previous knot, invariably getting the meat. According to Lockhart, who reports this incident, the trapper thought the animal so weird that he left the neighborhood to trap elsewhere.

It is said that a hunter may safely leave a carcass for one night but never for two, as the wolverines will on its second visit do away with it all. Why a wolverine should carry off knives, axes, kettles and such things is difficult to explain unless it be to mark them with his well known brand of ownership, the foul secretion.

Wolverines have such poor eyesight that they have been known to shade their eyes with their paws; and snowblindness sometimes kills them.

\section{ROCKY MOUNTAIN MARTEN}

\section{MUSTELA CAURINA ORIGENES (Rhoads)}

Mustela caurina origenes Rhoads, Proc. Acad. Nat. Scien. Phil., 1902, p. 458.

Description-Upper parts and sides wood brown; long hairs on dorsal region and rump broccoli brown; gular patch extensive; buffy orange; rest of under parts lighter than back; tail long; dark; ears edged with ochraceous buff. (Elliot.) Length 28.25; tail, vert., 8.25; hind foot, 3.0. (Rhoads.) They do not turn white in winter; that is, their winter coat is not very different in color from that of summer. (Seton.)

Distribution-Gerald Thorne of Logan has mounted several marten skins taken from the Uinta mountains. This animal is rare in this state, being confined to the mountains of the eastern section.

Mr. F. A. Wrathall dressed eight skins that were taken near Brighton, Salt Lake County, in the winter of 1917-18, and they are reported as fairly plentiful in that vicinity. 
Mr. McNeill of Bountiful, a well known trapper, says that he can always depend on getting martens on the streams about Kamas, Utah, and he used to trap them on the headwaters of the Provo, Weber and Duchesne rivers. S. B. Locke informs me that martens, though rare, are occasionally seen in the mountains of the La Sal national forest.

Habits-Like other members of the weasel tribe, the marten is a fierce, merciless creature of rapine, but unlike the mink and weasel, it avoids the abodes of man and loves the remotest depts of the wilderness. In the forest they climb trees with the agility of a squirrel and on the ground they hunt about under brush, moving with great rapidity. Practically every living thing within their power falls victim to their rapacity. They eat minks, weasels, squirrels, chipmunks, wood rats, mice of many kinds, conies, snowshoe rabbits, grouse, small birds and their eggs, frogs, fish, beetles, nuts, and a variety of wild fruits. Unlike minks and weasels, however, they do not usually kill more than they can eat. They make nests of grass, moss and leaves in hollow trees, under logs, among rocks or in holes in the ground. The young, from one to eight, naked and helpless, are born in April or May. (Nelson.)

Marten skins bring the trapper from $\$ 1.00$ to $\$ 65.00$ each according to color, size and condition, the dark being the most valuable, the brown next and the pale least valuable.

\section{MOUNTAIN WEASEL}

\section{PUTORIUS ARIZONENSIS (Mearns)}

Putorius arizonensis Mearns, Bull. Am. Mus. Nat. Hist. III, No. 2, pp. 234-235, 1891.

Description-Summer pelage: Upper parts clear dark brown, decidedly darker on head; tail the same, somewhat lighter beneath, and with black tip; upper lip and chin white; rest of under parts buff with a decided orange tint; upper surface of front feet and hind toes, and inner side hind legs yellow; soles of hind feet pale brown. According to Merriam, the color of the under parts varies quite considerably in depth and shade. The winter pelage is white with black tip to tail. In spring and autumn specimens are found showing the various stages of transition between the two pelages and are often very interesting. Measurements 
of male: Total length, 15.75 ; tail vert. 5.9 ; hind foot, 1.65 . Female: Total length, 14.0 ; tail vert. 5.1 ; hind foot, 1.6. (Warren.)

Distribution-Sierra Nevada and Rocky Mountains into British Columbia, not north of Siskiyou Mountains in the Cascade range. In Utah it may be found practically throughout the state, usually in the mountains and foothills. Clinton Milne of St. George says that in that vicinity these weasels are found in creek beds and thick under-brush. They are decreasing there. They are common in the La Sal National forest district, according to S. B. Locke.

Habits-In addition to ground squirrels, this species preys upon the snowshoe rabbit, especially in winter. (Seton.) The species has a wide vertical range from 5,000 feet to timberline. It frequents the piles of large boulders and debris in canyon bottoms and along mountain streams, where it preys chiefly upon mice, chipmunks and spermophiles. When surprised in the open, it immediately seeks refuge among the nearest rocks, but once in this safe retreat its curiosity overcomes its fear, and it is seldom out of sight for more than a moment. Its frisks in and out among the rocks, stopping now and then to crane its long neck at the observer, and even stands erect on its hind legs to get a better view of the object of its curiosity. (Cary.)

Revelling always in scenes of the most heinous butchery, sinking his long, white teeth deep into the throat of every victim his dauntless courage will permit him to tackle, and passing like a flash in search of more blood, more devil. ish killing, the mountainous weasel is truly the most mur derous animal for its size that roams the western wilds. An eagle, a mink, a coyote, or wolf will usually cease its killing when hunger has been appeased or at least gormandize for days on the victims of a one-night slaughter; but not so with the weasel; like the thugs of India, who murdered every one they could as a religious practice, he glories in his fiendish work of destruction. He is probably the wickedest and most unlovable fur-bearer in America.

Weasels growl, snarl, hiss, puff and make reiterated sharp barks at times. They chatter when angry, coo or chuckle to their young and bark at puzzling objects.

The mating season is about the third week in March; and though there is some evidence of pairing, the male cares not a whiff for the young. He will fight like a demon, however, if the female is disturbed when in his neighborhood. 


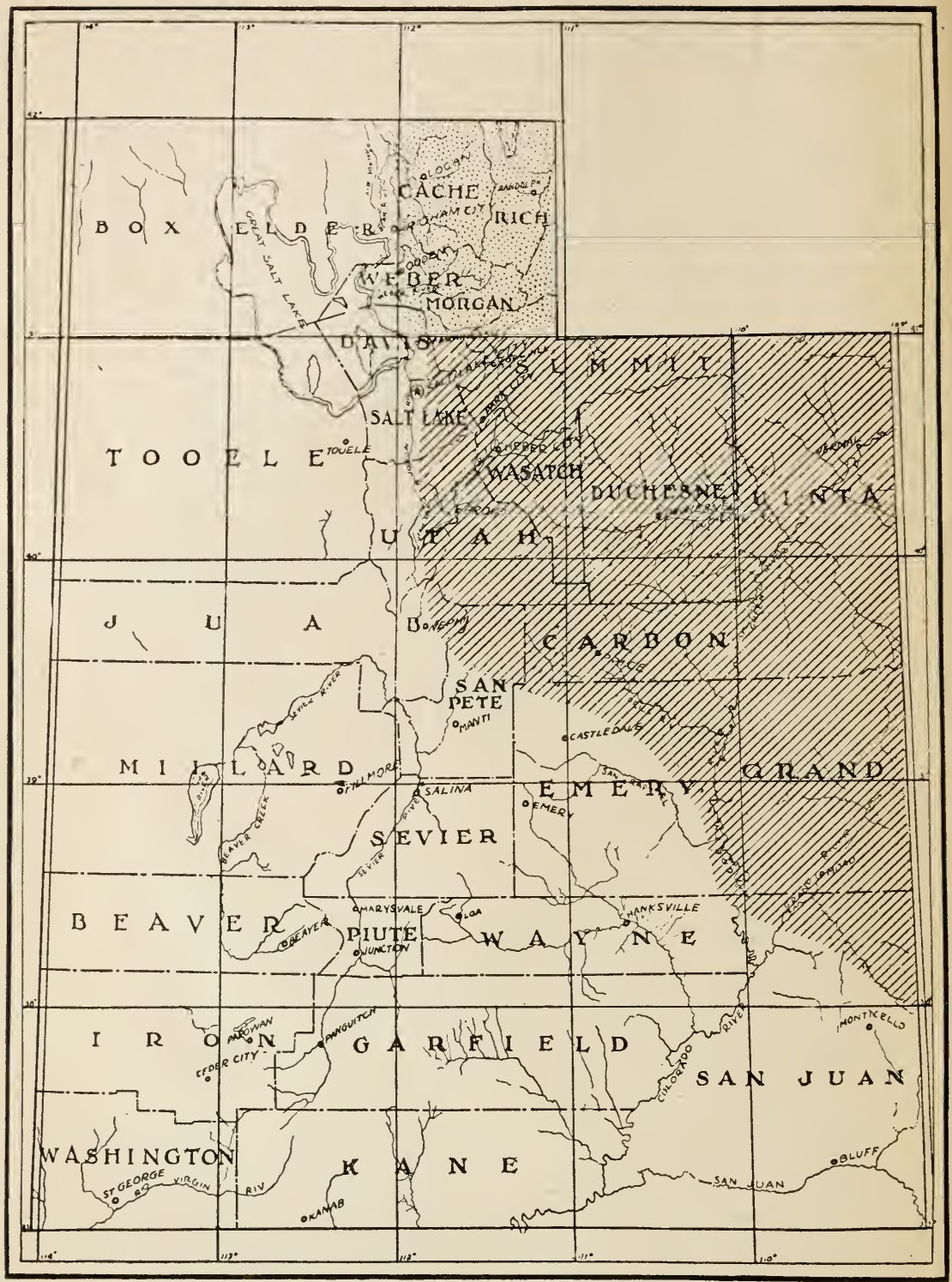

Map No. 28.-(Dotted area) Range of Mink (PUTORIUS VISON Schreber) in Utah. (Lined area) Range of Mink (PUTORIUS VISON LUTREOCEPHALUS Harlan). Based on E. T. Seton's map and records by Claude 'T. Barnes. 
After a period of forty days gestation, from four to eight young are born, which the mother hides and guards with a courage that would tackle an elephant. The little ones are blind for nine days and not until they are six or eight weeks old does the mother take the troop of young pirates forth to their lessons of carnage. The dying squeak, the final spasmodic quiver, the hot gushing blood-these are the delights of the weasel.

Ground squirrels are its principal food though it actually chases down the cottontail, which, trembling with fear, rushes into its burrow and awaits the inevitable assassin. Everything from a mouse to a turkey is included in the weasel's fare. Fifty chickens have been known to lie, the silent evidence of one night's work. Climbing better than chipmunks, the weasel chases them to their doom and forever prays on squirrels as well.

Weasels have a strongly developed storage habit. They have been known to drag from fifty to seventy-five rats into a compact heap, or cover a rabbit with snow-and then leave them to spoil!

Weasels are weasels' foes; for once the breeding is over, all of the adults fight, the males even fighting the females to death, the slightest difference in weight determining the victor.

Brown weasel skins are worth from 5 cents to 15 cents each, the white pelts being from 20 cents to $\$ 3.00$ each.

\section{MINK}

\section{PUTORIUS VISON LUTREOCEPHALUS (Harlan)}

Mustela lutreola Forst. Phil. Trans. LXII, 1772, p. 371. (nec Linn.)

Mustela canadensis Erxl. Syst. Reg. Anim. I, 1777, p. 455. (nec M. 1 canadensis of Schreber.)

Mustela vison Schreber, Saugth, III, 1777, p. 463.

Mustela winingus Barton, Am. Philos. Trans. VI, 1809, p. 70.

Mustela minx Ord. Guthrie's Geogr. 2d Am. ed. II, 1815, p. 291.

Mustela lutreocephala Harlan, Faun. Amer. p. 63, 1825.

Putorius nigrescens Aud. \& Bach. Quad. N. Am. III, 1853, p. 104, pl. CXXIV.

Putorius vison Elliot, Syn. N. Am. Mamm. F. C. M. Pub. II, 1901 , p. 338, fig. 67 . Zool. Ser.

Putorius vison lutreocephalus Elliott, Syn. N. Am. Mamm. F. C. M. Pub. II, 1901, p. 339. Zool. Ser.

Description-An ordinary male weighs about 2 pounds, but I have seen adults that were only $11 / 2$ to $13 / 4$ pounds. The largest I ever weighed was taken at Winnipeg, Novem- 
ber 1,1907 ; it turned the scale to 2 pounds 6 ounces. The females are considerably smaller than the males, weighing, according to Resseque, about 1 pound 10 ounces. In general the mink is nearly uniform umber-brown, darker and glossier on the back, and deepening on the tail nearly to black; the chin is more or less white, and there may be some white spots anywhere on throat, breast or belly, but these are very irregular; some specimens are totally without white. In the American species the white does not reach the upper lip. In the Siberian species the upper lip is normally white. This animal does not turn white in winter. The impression it gives as it dodges in the woods along the water is of a long, thin rat, with brown fur and hairy tail. (Seton.)

Distribution-The mink ranges over most of Canada and all of the United States except the southwestern portion. In Utah it is confined to the mountainous regions of the eastern half of the state. Typical vison have been found in the northern Wasatch mountains but most of the minks of this state may be referred to Lutreocephalus, larger than the type with shorter and paler fur. Minks are very rare in Utah. E. C. Shepard of Logan reports a few in Cache national forest, and S. B. Locke says that they occur along the streams of southeastern Utah.

Gerald Thorne informs me that he has both shot and trapped mink in the Uinta basin and that a few stragglers may still be found in the north and south sides of the Uinta mountains. He has seen two along the Logan river, where Ted Seeholzer caught six in 1916. Mr. F. A. Wrathall reports that he frequently sees mink in Big and Little Cottonwood canyons. He has received many from local trappers from time to time.

Habits-The food of the mink includes everything in the way of flesh, fish, or fowl it can conquer, and so furious is the little animal that it overcomes many living things, larger and stronger than itself.

Picture an umber brown, elongated little animal, so small that he could curl closely in your overcoat pocket, but withal a creature so ferocious, so bloodthirsty and so tenaceous that the famous bull terrier takes second place to him as a fighter, and you have some impression of the most truculent of all weasels, the mink, minx, or vison, as he is variously called. Yet if the paradoxical bit of ferocity be taken from its mother before his eyes are open, petted 
and treated kindly, he becomes as amiable as a housecat, doing little damage except by ferreting out food not intended for him.

All minks delight in the borderland between water and woods-between the otter and the weasel as it were. They can live in water and catch fish as does the otter or follow prey into the rushes and woods, over logs, into burrows and up rough or sloping trees, as does the weasel.

Each mink covers a large territory, probably five miles across, in a single season, hunting in one place until game becomes scarce, then roaming a mile or so away, up one stream and down another. Thus the male may have several nests or resting places in the hunting range.

Excepting during the mating season and when rearing the young, minks are solitary animals, a series of scented mud pies along commonly visited streams being their only designed means of communications.

The mink is not a noisy animal, yet it may growl, utter a deep, savage snarl, give a snarl or almost scream of defiance or a shrill screech when trapped.

Minks appear to be both polygamous and polyandrous. During the mating season-February and March-the males wander restlessly over the snow while the females apparently remain in their burrows. Caged minks have to be separated for the male mink is so determined to brood or feed the young that he is liable to smother them.

Any low situation within sound of the streams's murmur may be chosen for the mink's den, which consists usually of either a long burrow in a bank, or a hole under a log, stump or root. From three to ten young are born towards the last of April, the period of gestation being forty-two days. The tiny, blind, naked things are about the size of one's little finger, pale and helpless. Their eyes open at the end of five weeks, after which the mother begins to give them solid food, such as minnows.

Trout a foot long are sometimes captured by minks; and other food consists of frogs, toads, tadpoles, gray rabbits, snakes, clams, crawfish and carrion. It follows muskrats persistently and will ravage a whole chicken coop in a single night.

Mink pelts are worth from 25 cents to $\$ 14.00$ each, the darker skins being the most valuable. 


\section{MEXICAN OTTER}

\section{LUTRA CANADENSIS SONORA (Rhoads)}

Lutra hudsonica sonora Rhoads, Trans. Am. Philos. Soc., N. S. XIX, 1898, p. 431.

Lutra canadensis sonora Elliot, Syn. N. Am. Mamm., F. C. M. Pub., II, 1901, p. 353. Zool. Ser.

Description-The genus lutra comprises weasels of large size, with short legs, long tails; adapted for life in the water, having dense oily fur, webbed feet. The muskrat is protected against the cold water by a fine robe of dense fur; the whale by a thick layer of fat under the skin; the otter is happy in the possession of both, and can enjoy the coldest water in the coldest of weather. The length of the typical canadensis is about forty inches, though sonora is a larger and more yellowish form. (Seton.) The typical canadensis is described as follows: In general the color is dark rich glossy brown, becoming paler and grayer below; the brown of the head and muzzle changes on lips, cheeks, chin and throat rather abruptly, into a pale brownish gray, almost a grayish white. (Seton.)

Distribution-If one may judge the number of streams in Utah named after the otter such as those in the Fish Lake district, the original distribution of this animal included the entire eastern half of the state. This is verified from Seton's map; and his maps generally have been found by the author to be surprisingly accurate so far as the distribution of mammals in this state are concerned despite the fact that his work takes Manitoba as a basis. This animal is, however, quite rare; and specimens are not available to prove just which form inhabits the Wasatch and Uintah districts. It may be found later that the typical canadensis is represented in the Cache national forest. Gerald Thorne of Logan informs me that otters are occasionally taken along Green river, especially in the Split Mountain canyon and canyons above. He mounted two skins trapped by Nathaniel Galloway about six miles above Jensen, Utah, near the mouth of Split Mountain canyon. At Indian dances in the Uintah district he has often seen otter skins worn and their owners said that they caught them at the headwaters of the Uintah and Duchesne rivers.

Habits-The otter spends its life near clear, cold, troutfavored streams, searching, even in winter, for those rapids and falls where the ice does not cover the stream. The 
individual range covers a district of several miles extent. It is not either a sociable or gregarious animal, the three or four sometimes seen together in the autumn being usually a mother with her family.

An otter sometimes utters a loud sniffing sound, and in times of danger it may snarl or growl, or even chirp to express hunger.

The mating season occurs towards the end of February; the nest is built somewhat after the fashion of that of the muskrat in that the entrance is under water. The young, born in mid-April, from one to three in number, are blind for some weeks.

One of the most peculiar habits of this animal is its construction of slides in the mud or snow, down which they slip for the sheer fun of it.

Among the items that enter into'an otter's bill of fare may be mentioned trout, frogs, crayfish and wild fowl. 


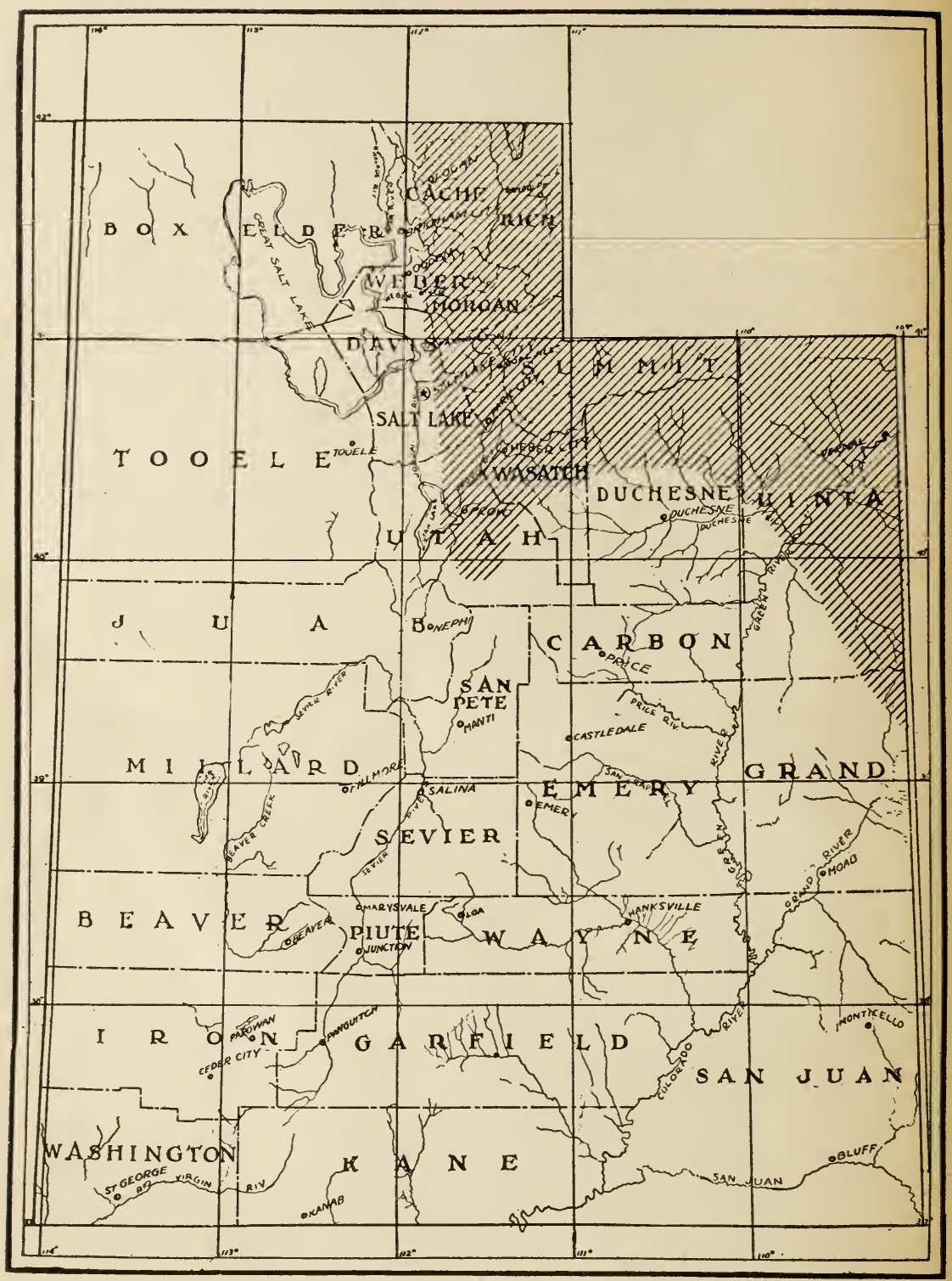

Map No. 29.-Range of the Masked Shrew (SOREX PERSONATUS I. G. St. Hilaire) in Utah. 


\title{
Order INSECTIVORA The Insectivores
}

\author{
Family SORICIDAE, Shrews \\ Subfamily SORICINAE

\section{DOBSON'S SHREW}

\section{SOREX DOBSONI (Merriam)}

Sorex dobsoni Merriam, N. A. Faun. No. 5, p. 33, 1891.

Sorex vagrans dobsoni Elliot, Syn. N. Am. Mamm., F. C. M. Pub., 1901, p. 370.

Description-Similar to $\mathbf{S}$. personatus in size and coloration, but differing in having a somewhat longer tail and in cranial and dental characters. Upper parts uniform dull sepia brown, not darker on the rump. Under parts drab slightly tinged with brown. Tail indistinctly bicolor, concolor with the upper and under surfaces of the nody. The skull is larger and heavier than that of $\mathrm{S}$. personatus. (Merriam.)

Distribution-Rocky mountains in northern Idaho, and western Montana, also in Big Snowy and Prior mountains, Montana, Big Horn mountains in Wyoming, and Wasatch mountains, Utah.

\section{MASKED SHREW}

SOREX PERSONATUS (1. Geoff. St. Hilaire)

Sorex personatus 1 . Goeff. St. Hil., Mem. du Mus. Hist. Nat. Paris, XV, 1827, p. 122.

Sorex forsteri Rich., Zool. Jour., III, 1828, p. 516.

Sorex cooperi Bachm., Journ. Acad. Nat. Sci. Phila., 1837, p. 388.

Sorex fimbripes Bachm., Journ. Acad. Nat. Sci. Phil., 1837, Amphisorex lesueuri Duvern., Mag. Zool., Mamm., 1842, p. 33. Sorex platyrhynchus Linsley, Sillim. Am. Journ. Scien. XLIII, 1842 , p. 346.

Otisorex platyrhinus DeKay, Zool. N. Y., I, 1842, p.-22.

Sorex haydeni Baird, N. Am. Mamm, 1857, p. 29.

Sorex richardsoni Dobson, Mon. Insectiv., I, 1890, Pt. III.

Sorex idahoensis Merr., N. Am. Faun., No. 5, 1891, p. 32.

Description-The summer coat, above, sepia brown mixed with dark-tipped hairs; shaded into ashy white or fawn below; tail, dark brownish above and all around at 
tip, whitish below, rather sharply defined, i. e., tail bicolored. Winter coat, more grayish above and lighter, sometimes pure white below. A chestnut phase is sometimes found. The sexes are alike. The average total length is about $315 / 16$ inches; weight about 47 grains. (Seton.) This very diminutive shrew has a head slender and acutely elongated; the body very slender. The muzzle is naked and quite deeply divided. The eye is rather prominent, its center nearer the anterior base of the concha than the muzzle, showing this to be less elongated than in some species of the group. The ear is rather large and open, the concha directed backward. The tail is about as long as the body (without head) or a little longer. It is very thin at the base, about the diameter of the tibia; it, however, swells rapidly towards the middle, and then tapers gently to the tip. It is round and densely clothed with long hairs concealing the annuli, and ending in a pencil. The feet are small, especially the hinder ones, which are only about four tenths of an inch long. These are naked below, except at the heel, where they are covered with hairs, except a narrow space along the median line, which is, however, concealed by the overhanging bristles. The rest of the sole is covered with small tubercles, with six longer ones interspaced. The feet are rather broad, and covered with longish lustrous hairs. (Baird.)

Distribution-This shrew is confined to the Wasatch and Uinta mountain districts in this state. It is not common.

Habits-These tiny animals live among the vegetation and debris on the surface of the ground or in little burrows below. With the moles they are members of the Order Insectivora and depend mainly on insects and meat for food. consists of small balls of dry leaves, grasses or other soft This species is the smallest of our mammals. Its nest vegetation placed under a $\log$ or in a stump; and two or more litters of from six to ten young each are raised during the summer and fall. They run along the tunnels of mice and search for insects, larvae, worms, and seeds. When two are placed together in captivity they fight to the death, the victor devouring the vanquished. The Eskimos have a deadly fear of shrews, which they believe to be able to dart at them and pierce into their hearts. (Nelson.) 


\section{DUSKY SHREW}

\section{SOREX OBSCURUS (Merriam)}

Sorex vagrans similis Merriam, N. A. F. No. 5, pp. 34-35, Pl. IV, fig. 3, August, 1891.

Description-Size, rather small; tail about equal to body without head; ears inconspicuous; third unicuspid much smaller than fourth. Similar to Sorex dobsoni, but with smaller ears, broader palate, and broader unicuspidate teeth. Compared with $\mathrm{S}$. vagrans, it is slightly larger, with longer tail and larger molariform teeth. Color: Upper parts uniform dull sepia brown, under parts ashy; tail bicolor; upper side concolor with back or slightly darker, under side whitish. In winter pelage the upper parts are ashy gray and the under parts nearly white. (Merriam.)

Distribution-British Columbia, and mountains of western Washington, Montana, Wyoming, Utah, and Colorado, south in California to Mount Whitney. Utah specimens have been taken at Provo, Manti, and in the Wasatch mountains.

Habits-The family, Soricidae or Shrews, comprises small mouselike creatures, but most of them are smaller than any mouse, and in anatomy as different from the mice as a small badger is from the big gray rabbit. This we should realize if we could set together a mouse and a shrew, each magnified to the size of a sheep. Their most striking peculiarity is the absence, or apparent absence, of eyes and ears; next, their long sharp nose, and last, but of most importance, their teeth. (Seton.) The food of this species consists mostly of worms and insects.

All American shrews have two pelages, which may be roughly designated as summer and winter coats, though by no means corresponding strictly with these seasonal limitations. As usual among small mammals, the molt takes place at different date among individuals of the same species, so that it is not rare to capture specimens in different pelages on the same day. The winter pelage is usually plumbeous, dusky, or ash gray; the summer pelage sepia brown or chestnut. (Merriam.) 


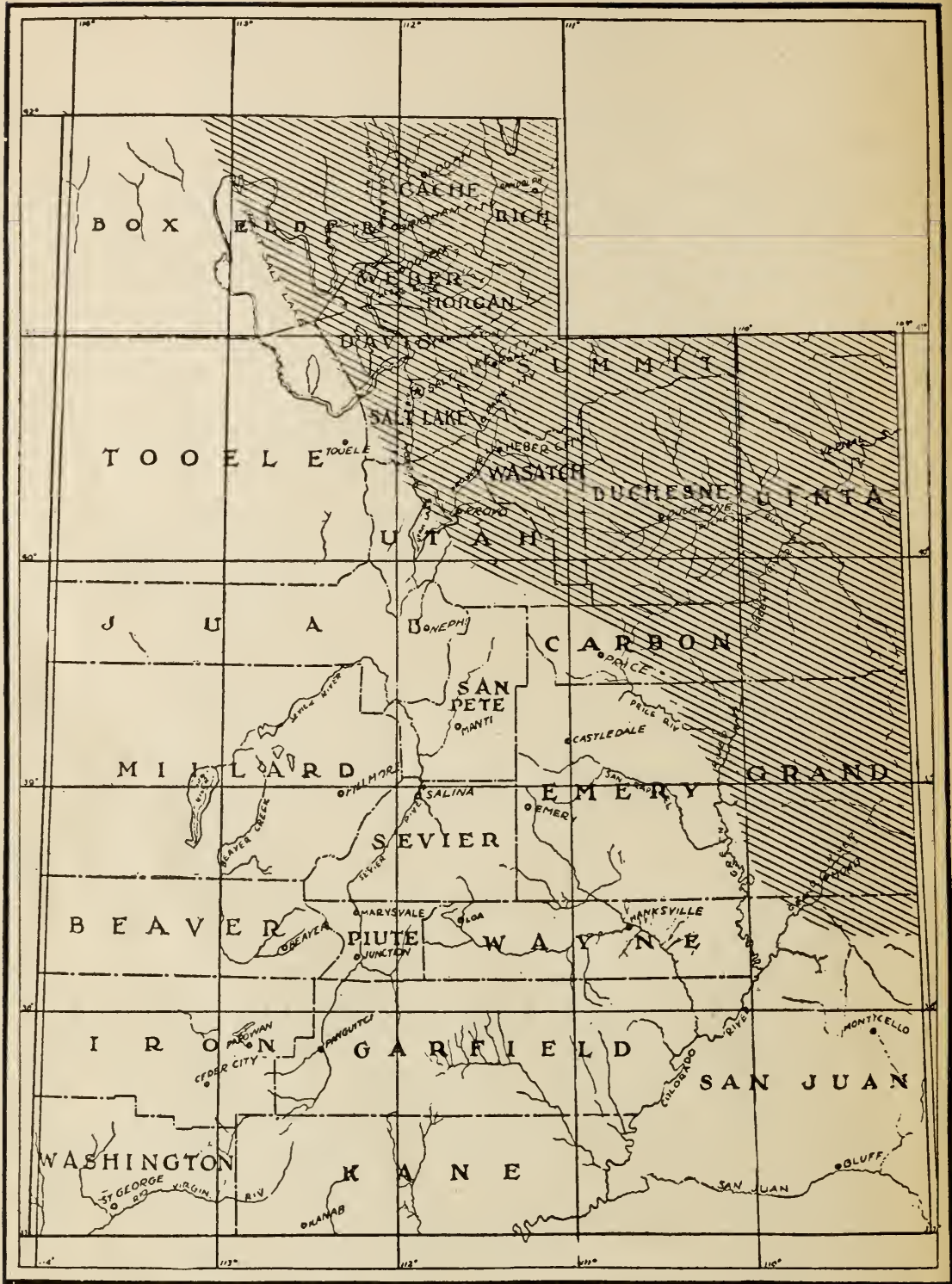

Map No. 30.-Range of the Navigator Shrew (NEOSOREX PALUSTRIS NAVIGATOR Baird) in Utah. Based on map of E. T. Seton and records by Claude T. Barnes. 


\section{NAVIGATOR SHREW}

\section{NEOSOREX PALUSTRIS NAVIGATOR (Baird)}

Neosorex navigator Baird, N. Am. Mamm., p. 11, 1857.

Neosorex palustris navigator Elliot, Syn. N. Am. Mamm, F. C. M. Pub. II, 1901, p. 379. Zool. Ser.

Sorex palustris Merr., N. A. F. No. 5, 1891, p. 35 (nec Richardson).

Description-Body rather thick and full; feet very large, broad, and long, entirely naked beneath, covered above with short stiff hairs; the soles and palms margined with a fringe of stiff parallel ciliated bristles, longest on the soles; the fingers and toes all with a separate ciliation of shorter hairs; the soles are occupied by a pavement of crowded, minute scale-like tubercles, extending from the heel to the bases of the toes; hind feet about twice the length of the fore-feet: the ears are small, and in the dried skin very inconspicuous; the whiskers are numerous, the longest reaching back to the arms; the tail is longer than the body, tetragonal in the dried animal, a pointed pencil of hairs at the tip; the hairs elsewhere rather short. but close pressed and of uniform length everywhere. The fur is long, and very full and soft; its color above and on the sides is a mixed hoary and smoky brown; the hairs being lead color for most of their length from the base, grayish towards tip, then smoky brown, sometimes dark brown at the end. Intermixed are longer hairs, black with grayish tips. The under parts are of a dull grayish-white, with a tinge of brownish yellow, in strong contrast with the color of the back and sides. The feet, with the fingers, are of a mixed brown and gray, except on the inner edge, where they are colored like the belly. The tail is like the back, except on the under surface, where it is of a sharply defined whitish, like the belly. Length of head and body, $21 / 12$ inches ; tail, 3. (Baird.)

Distribution-Rocky Mountains from British Columbia to southern Colorado, Sierra Nevada of California, to Sequoia National Park. Specimens have been taken at Park City, Utah, and at other points in the Wasatch Mountains. Though S. B. Locke reports that shrews occur in the La Sal Mountains, I have never seen specimens.

Habits-This species is aquatic, living on the borders of streams and marshes. It is frequently found in the moss at the edge of moutnain streams or in the dense vegetation of cold bogs and mountain meadows. It probably feeds on meadow mice, as well as insects and worms. 


\title{
Order CHIROPTERA: Bats
}

\author{
Family VESPERTILIONIDAE, Common Bats \\ Subfamily VESPERTILIONINAE
}

\section{FORT YUMA BAT}

\section{MYOTIS YUMANENSIS (H. Allen)}

Vespertilio yumanensis H. Allen, Monogr. N. Am. Bats, p. Jo, 1864.

Vespertilio macropus H. Allen, Proc. Acad. Nat. Sci. Phila., p. 288 (nec Gould, 1854) 1866.

Vespertilio nitidus (pedomorphic variety) H. Allen, Monogr. Bats N. Am., pp. 72-73, 1893.

Vespertilio albescens $H$. Allen, Monogr. Bats. N. Am. p. 87, (part, nec Geoff., 1805) 1893.

Vespertilio nitidus macropus H. Allen, Monogr. Bats. N. Am., p. $100,1893$.

Description-Size small length 74-88mm. ; forearm 32-37 $\mathrm{mm}$.; calcar distinct, considerably longer than free border of interfemoral membrane,terminating at a well-marked lobule; free border of uropatagium naked; ears moderate; wings from base to toes, but on account of extent of web between toes apparently from side of metatarus; feet very large and

ong as compared with other small American species. Ears: The ears are moderately long; laid forward they reach straight for a short distance at base, then strongly convex, and finally straight or even slightly concave just below tip. The tip is narrow and abruptly rounded off. The posterior border is concave from the tip to the widest part of the auricle, just below mid height, then strongly convex to basal notch, which isolates a well-marked lobe. The fur shows no peculiarities in distribution. On the middle of the back it averages about $6 \mathrm{~mm}$. in length. Color pale wood brown, varying to broccoli brown; belly dirty whitish; the fur everywhere light plumbeous at base; ears and membrane light brown; the uropatagium and wing membranes edged with whitish. (Miller.)

Distribution-Austral zones and lower edge of Transition zone from the southwestern United States to San Luis Potosi and Michoacan, Mexico. In Utah specimens have been taken at Provo. 


\section{SILVER-HAIRED BAT}

\section{LASIONYCTERIS NOCTIVAGANS (LeConte)}

Vespertilio noctivagans Le Conte, McMurtrie's Cuvier's An. Kingdom, 1, p. 31, 1831.

Vespertilio auduboni Harlan, Mont. Am. Journ. Geol. and Nat. Hist., 1, p. 220, 1831.

Vespertilio oulverulentus Temminck, Monogr. de Mammalogie, 11 , p. $325,1835$.

Scotophilus noctivagans H. Allen, Monogr. N. Am. Bats, p. 39, 1864.

Lasionycteris noctivagans Peters, Monatsber. K. Preuss. Akad. Miss., Berlin, p. 648, 1865.

Vesperugo noctivagans Dobson, Catal. Chiroptera Brit. Mus., p. $238,1878$.

Lasionycteris noctivagans $H$. Allen, Monogr. Bats, N. Am., p. $105,1893$.

Description-The fur is deep, blackish, chocolate brown throughout, many of the hairs on the back, belly and furred part of interfemoral membrane tipped with silvery white. The white tips are most numerous on middle of back. They are absent, or nearly so, from face, crown and throat. (Miller.)

Distribution-North America from Atlantic to the Pacific, and including the northern half of the United States. It breeds in Utah probably only in the northeastern section though its winter range includes the northern half of the State.

Habits-Like many other bats it has a decided liking for waterways, coursing up and down streams and rivers, and circling around lakes and ponds. (Merriam.) The breeding season extends throughout August and September and the male takes no interest whatsoever in the rearing of the young. The period of gestation is apparently ten months. (Seton.) This bat prefers hollow trees where the mother takes advantage of whatever she may find there as a nest. The young commence to fly when about three weeks old.

Bats gather their food during the twilight of morning before sunrise and evening before dark. This species is especially fond of mosquitoes; in fact, no one should kill bats of any kind in this state. 


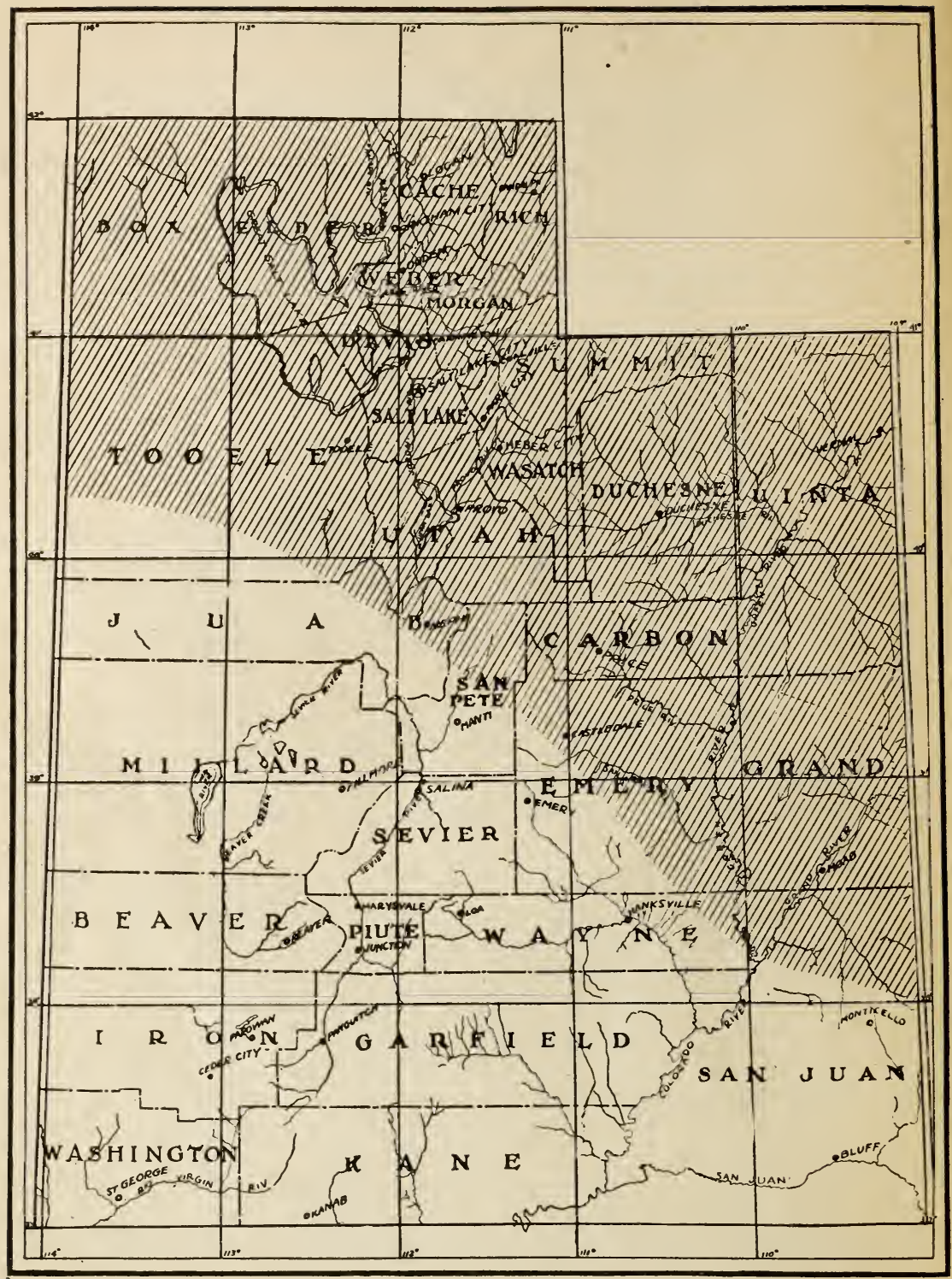

Map No. 31.-Range of the Silver-haired Bat (LASIONYCTERIS NOCTIVAGANS Le Conte) in Utah. Based on E. T. Seton's map. 


\section{WESTERN BAT}

\section{PIPISTRELLUS HESPERUS (H. Allen)}

Scotophilus hesperus H. Allen. Mon. N. A. Bats, 1864, p. 43. Vesperugo merriami Dobson, Cat. Chirop., Brit. Mus. 1878, p. 228.

Pipistrellus hesperus Elliot, Syn. N. Am. Mamm. F. C. M. Pub., II, 1901, p. 409.

Description-Size very small; thumb short, ears shorter and more bluntly rounded than in other American members of the genus reaching barely to nostril when laid forward. The fur extends on basal third of ears but barely reaches extreme base of interfemoral membrane, and on wing membrances invades merely a very narrow strip close to the body. Color light yellowish gray or whitish gray, the fur everywhere deep plumbeous at the base. In some specimens the hairs on the back have faint dark subterminal areas which, however, are visible on close inspection only. Ears, muzzle face and membrane black. A narrow whitish border on wing membrane between foot and fifth finger. Foot small, distinctly less than half as long as tibia, naked or with a few almost invisible whitish hairs on dorsal surface. (Miller.)

Distribution-The western bat is found in the lower Austral zone in the western United States from western Texas to the Pacific coast. Specimens have been taken at St. George, Utah.

\section{BROWN BAT}

\section{VESPERTILIO FUSCUS (Beauvois)}

Vespertilio ursinus Temminck, Monogr. de Mammalogie, II, p. 235 .

Vespertilio fuscus Beauv., Cat. Peale's Mus. Phil, 1796, p. 14. Vespertilio carolinensis Geoff., Ann. Mus. Nat. Hist. Paris, VIII, 1806 , p. 193.

Vespertilio phaiops Rafin., Am. Month. Mag., III, 1818, p. 445.

Eptesicus melanops Rafin., Ann. Nat., 1820, p. 2.

Vespertilio arquatus Say, Long's Exped. Rocky Mts., 1, 1823, p. 167 note.

Scotophilus greenii Gray List. Spec. Mamm. Brit. Mus., 1, 1843 , p. 30 .

Eptesicus fuscus Beauv. Cat. Peale's Mus. Phil., p. 14.

Vesperugo serotinus var Vesperus fuscus Dobson. Cat. Chir. Brit. Mus., p. 193.

Description-In color it is wood brown throughout, paled below; fur never silver tipped. Length $4 \frac{3}{16}$. to 5 inches; tail $1^{1 / 2}$ to $2 \frac{1}{16}$ inches; forearm $1^{3 / 4}$ to $17 / 8$ inches. Weight of an adult, one-half ounce. (Seton.). 
Distribution-Practically the entire United States. Utah specimens have been taken at Ogden and at St. George, as well as in Cache county and at Laketown. Its range includes the entire state.

Habits-This bat prefers open ways between trees such as streets. It is a frequenter of towns and cities, and it is the last of the bats to appear each evening. Its breeding habits are unknown despite the fact that its range includes most of North America. It has an enormous appetite for bugs and insects and drinks water copiously.

\section{LITTLE CALIFORNIA BAT}

\section{MYOTIS CALIFORNICUS (Aud. \& Bach.)}

Véspertilio californicus Aud. \& Bach. Journ. Acad. Nàt. Sci. Phila. p: 280 (California) 1842.

Vespertilio nitidus H. Allen, Proc. Acad. Nat. Sci. Phila. p. 247 (Monterey, California) 1862.

Vespertilio nitidus H. Allen, Monogr. N. Am. Bats, p. 60, 1864.

Vespertilio oregonensis H. Allen, Monogr. N. Am. Bats, p. 61, (Cape St: Lueas and Fort Tejon); 1864.

Vespertilio obscurus H. Allen, Proc. Acad. Nat. Sci. Phila., p. 281 (Lower California) 1866.

Vespertilio volans H. Allen, Proc. Acad. Nat. Sci. Phila., p. 282 (Cape St. Lucas) 1866.

Vespertilio exilis H. Allen, Proc. Acad. Nat. Sci. Phila., p. 283 (Cape St. Lucas) 1866.

Vespertilio tenuidorsalis H. Allen, Proc. Acad. Nat. Sci. Phila., p. 283 (Cape St. Lucas) 1866:

Vespertilio yumanensis H. Allen, Proc: Acad Nat. Sci. Phila., p. 283) nec H. Allen, 1864) 1866.

Vespertilio nitidus Dobson, Catal, Chiroptera Brit. Mus., p. 318, 1878.

Vespertilio melanorhinus Merriam, N. Am. F. No. 3, p. 46, Sept. 11, 1890 (San Francisco Mt., Arizona) 1890.

Vespertilio albescens melanorhinus H. Allen, Monogr. Bats, N. Am., p. 91, 1893.

Vespertilio nitidus H. Allen, Monogr. Bats, N. Am., p. 84, 1893.

Vespertilio nitidus henshawi H. Allen, Monogr. Bats N. Am., p. 103 (Wingate, N. Mexico) 1893.

Vespertilio nigricans H. Allen, Monogr. Mats N. Am., p. 97 footnote (nec Maximilian 1826) 1893.

Description-Smallest species of Myotis known to occur in the United States. Length, 76 to 87 ; forearm, 30 to 36 . Calcar about as long as free border of uropatagium, very slender but distinct and with a more or less well developed lobule at tip, outer edge with a distinct keel. Legs slender, the small feet reaching when extended backward to within 
about $5 \mathrm{~mm}$. of tip of tail. Free border of uropatagium naked. Ears moderate, reaching just beyond tip of nose. Wings from base of toes. Fur on back distinctly darker at base than at tip. The fur is soft, full and long, that on middle of back averaging about $8 \mathrm{~mm}$. in length. Color light yellowish gray paler on the belly, the fur everywhere dark plumbeous at base. Membranes, ears, lips, and muzzle blackish. (Miller.)

Distribution-Austral zones and lower part of Transition zones throughout the western United States and Lower California, east to Wyoming and Texas.

\section{TRUE'S BAT: LITTLE BROWN BAT}

\section{MYOTIS LUCIFUGUS LONGICRUS (True)}

Vespertilio longicrus True, Science, VIII, p. 588, 1886.

Vespertilio nitidus longicrus $H$. Allen, Monogr. Bats N. Am., p. 103.

Vespertilio Albescens (melanic phase) H. Allen, Monogr. Bats N. Am., p. 92.

Description-The fur shows no peculiarities in distribution. In color it is darker and duller than in the typical subspecies but the difference is apparently never very striking. (Miller.) Above dark; underparts paler, with grayish cast; base of hair above and below blackish ; ears and membranes look blackish, though brown by transmitted light. (Warren.)

Distribution-Boreal and Transition zones from Puget Sound east to Wyoming south at least to Arizona and southern California.

Habits-This is a cave bat though hollow trees and farm houses are sometimes occupied by it. It flies quite like a chimney swift. Its voice is so delicate that some people with good hearing cannot hear it. The mating season of this species is August and early September; and the period of gestation is about ten months. Usually two young are raised; and it is said the mother carries them with her until they are about two weeks old.

The food of this species consists of insects, which it catches on the wing. Bats go twice or three times a day for water, being drinkers. An annual migration takes place though at times the species hibernate for a period of inclement weather. 


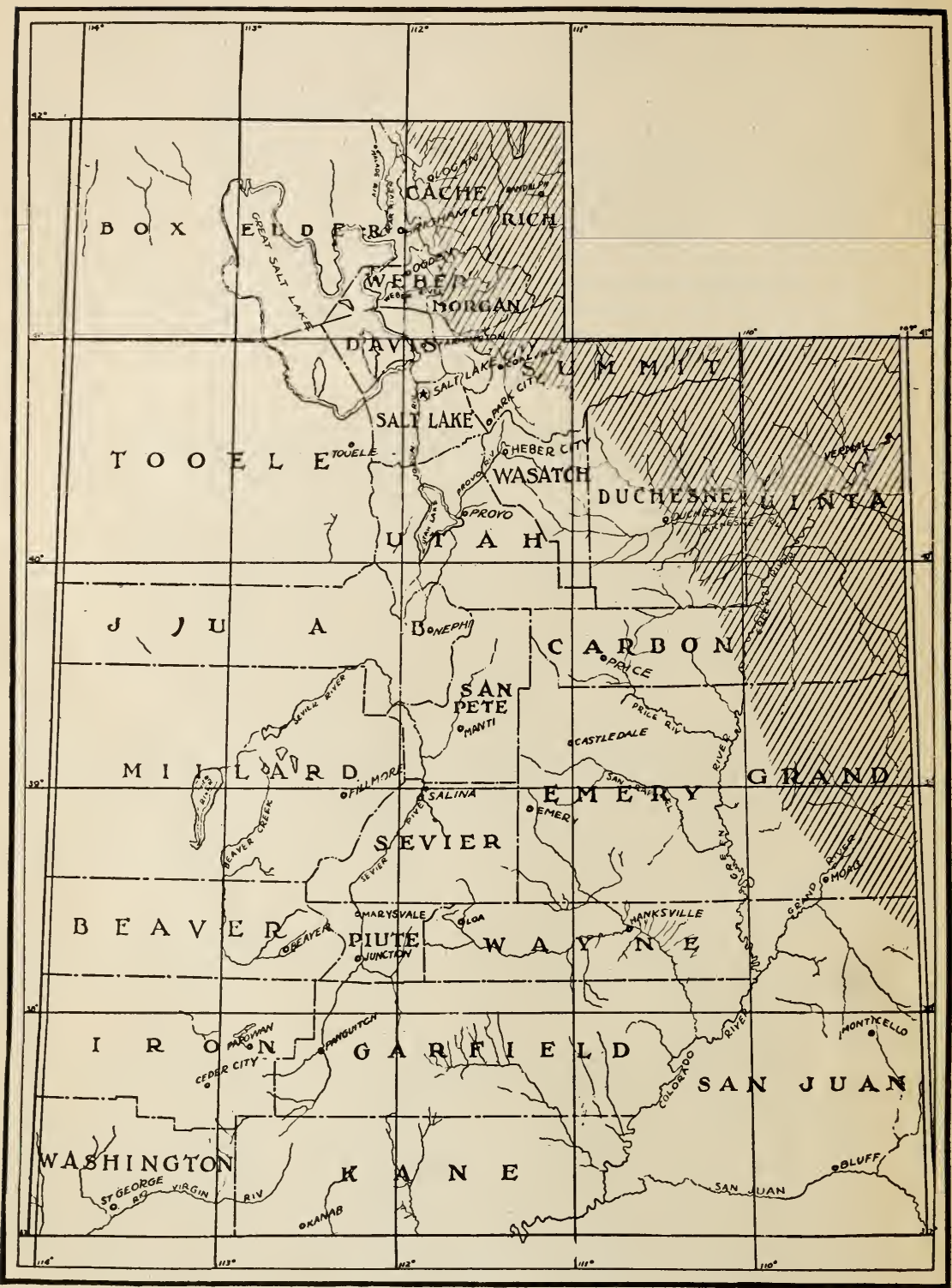

Map No. 32.-Breeding range of Hoary Bat (LASIURUS CINEREUS Beauvois) in Utah. Based on map of E. T. Seton. 


\section{LONG-EARED BAT}

\section{MYOTIS EVOTIS (H. Allen)}

Vespertilio evotis H. Allen, Monogr. Bats N. Am. p. 48, 1864.

Vespertilio evotis Dobson, Catal. Chiroptera Brit. Mus., p. 324, 1878.

Vespertilio albescens evotis H. Allen, Monogr. N. Am. Bats, p. $89,1893$.

Vespertilio chrysonotus J. A .Allen, Bull. Am. Mus. Nat. Hist. VIII, p. 240, November 21, 1896.

Description-Size large; Calcar longer than free border of uropatagium, slender, distinct, and with a more or less well developed lobule at the lip. Free border of uropatagium naked or very indistinctly ciliate. Ears very long, reaching 7 to $10 \mathrm{~mm}$. beyond tip of nose. Wing from base of toes. The fur is full, soft, and not peculiar in distribution. It is light yellowish brown, paler ventrally, the hairs everywhere dusky slate at base. (Miller.)

Distribution-Austral and Transition zones from the Pacific Coast to the eastern edge of the Rocky Mountains; south to Vera Cruz.

\section{THE HOARY-BAT OR GREAT NORTHERN BAT}

\section{LASIURUS CINEREUS (Beauvois)}

Vespertilio cinereus Beauvois, 1796, Cat. Peale's Mus., Phila., p. 15.

Lasiurus cinereus H. Allen, 1864, Monog. Bats N. A., p. 21.

Description-Total length 5 to $5 \frac{1}{2}$ inches; spread 15 to -17 inches. The fur next the body is dully blackish, but this does not ordinarily show; the general under color visible is a soft sienna or orange buff, much grayer on breast and belly; but on the chest and upper parts each hair has a dark brown zone, and, finally, a silver white tip; the general effect is rich, deep brown, exquisitely frosted over with white; the chin is pale brown or yellow; the ears have black rims, and the muzzle is more or less black. When in air this species may be distinguished from all by its long, pointed wings, great size and swift zigzag flight. (Seton.)

Distribution-This species ranges over practically all of the continent of North America, its breeding range being 
mostly in Canada and its winter range in the United States. It breeds in Utah in the northeastern section and migrates to the south in winter, covering perhaps all of the state.

Habits - This bat prefers woods and waters, as it habitually seeks mosquitoes and other insects in the thick woods. Its mating season begins the first of August; and usually four young are raised. 


\section{N D E X}

A

Alces americanus ...................................................................... 9

Ammospermophilus leucurus cinnamomens .............................. 47 .

Antelope ....................................................................................... 24

Antelope chipmunk ........................................................................ 43

Antelope Map ............................................................................ 23

Antelope squirrel .............................................................................. 47

Antilocapra americana ................................................................. 23

Apache pocket mouse ................................................................... 69

Arizona wood rat ............................................................................... 74

Armed spermophile ......................................................................... 49

Aztec harvest mouse ..................................................................... 69

B

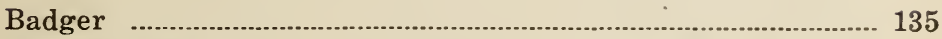

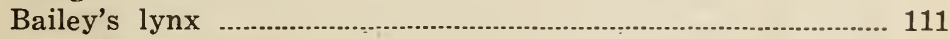

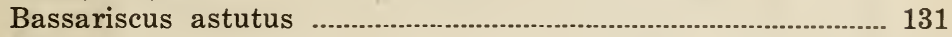

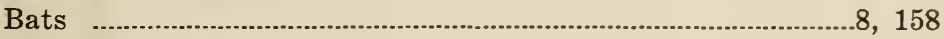

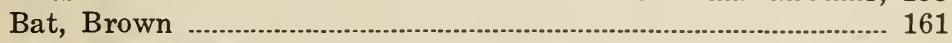

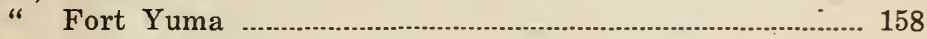

“ Great Northern ......................................................................... 164

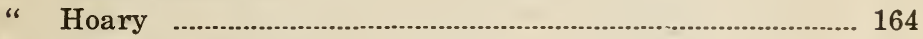

“ Little brown ............................................................................. 163

“ Little California ................................................................... 162

“ Long eared ............................................................................ 165

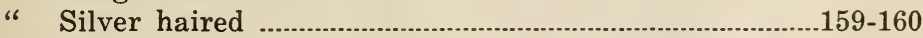

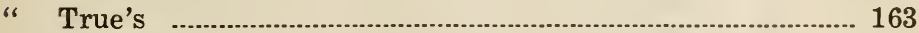

“ Western ......................................................................................... 161

Bay Lynx ........................................................................................ 111

Bear, Baird grizzly ............................................................. 8, 127

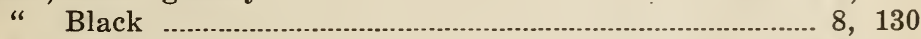

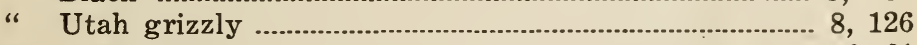

Beaver, Sonoran ......................................................................... 6, 61

Big footed vole ................................................................................... 78

Bighorn ................................................................................................ 26

Bison bison ............................................................................................. 31

Black-browed mole mouse ............................................................... 64

Black-eyed grasshopper mouse ..................................................... 64

Black Hills Cottontail ........................................................................ 97

Black Hills Cottontail (Map) …................................................... 98

Bobcat _.............................................................................................. 111

Bovidae ................................................................................................ 26

Bubonic plague caused by rats ................................................. 63

Buffalo

Buffalo (Map) ............................................................................ 30

C

Callospermophilus lateralis .......................................................... 46

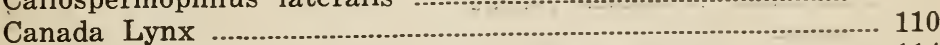

Canidae ….................................................................................................114 


\section{C-(Continued)}

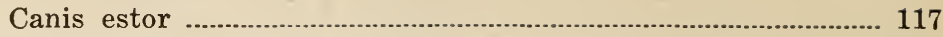

Canis lestes .................................................................................... 117

Canis occidentalis .............................................................................. 114

Cantankerous vole ........................................................................... 77

Canyon mouse, Golden breasted .................................................... 66

Carcajou ............................................................................................ 139

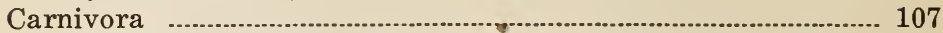

Castor canadensis frondator ................................................... 60, 61

Castoridae ....................................................................................... 61

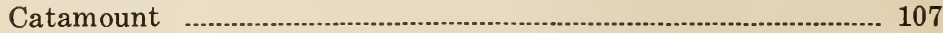

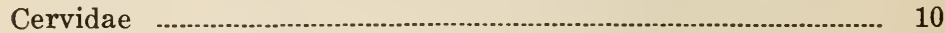

Cervinae _............................................................................................. 10

Cervus canadensis .............................................................................. 12

Cinnamon bushy-tailed wood rat ................................................... 74

Cinnamon chief hare ....................................................................... 92

Chickaree, Fremont's ........................................................................ 35

Chickaree (Map) ….......................................................................... 34

Chickaree, Wind river mountains ................................................... 33

Chickaree, Wind river mountains (Map) ...................................... 34

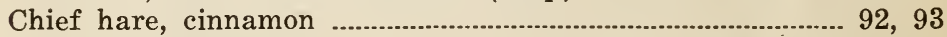

Chihuahua mule deer ..................................................................... 20

Chipmunk, Beaver mountains ........................................................... 42

“ Beaver valley ........................................................... 41

“ Busy ........................................................................... 40

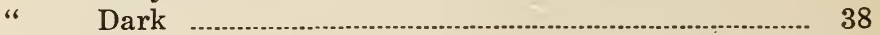

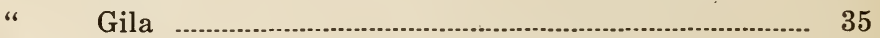

“ Hopi ……....................................................................... 36

“ $\quad$ Painted .............................................................................. 40

“ $\quad$ Related ................................................................................ 39

“ Utah ................................................................................ 37

“ Wasatch …......................................................................... 39

Chiroptera …...................................................................................... 158

Citellus armatus ........................................................................... 49

Citellus castanurus ............................................................................... 47

Citellus elegans ….................................................................................... 49

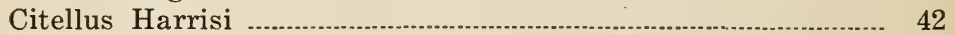

Citellus leucurus .......................................................................... 43

Citellus mollis ...................................................................... 48

Citellus townsendi ……................................................................... 48

Citellus tridecemlineatus parvus ..................................................... 45

Citellus variegatus grammurus ................................................ 50

Citellus variegatus Utah .............................................................. 50

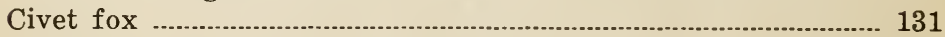

Cliff mouse, Rowley ........................................................................ 66

Colorado desert jack rabbit ............................................................ 105

Colorado desert jack rabbit (Map) …......................................... 96

Colorado pocket gopher ................................................................... 85

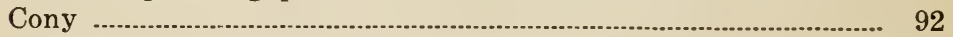

Cottontail, Black Hills …................................................................ 97

Cottontail, Colorado (Map) ……........................................... 96, 97

Cottontail, Wyoming (Map) _.................................................... 95, 96

Cougar _........................................................................................... 107

Coyote, Noland's ranch _........................................................................ 11 
C-(Continued)

Coyote, Mountain

Coyote, Robber

Cricetinae

Crotalus oregonus ....................................................................... 75

Cynomys gunnisoni zuniensis ................................................... 55

Cyonmys leucurus .......................................................................... 52

Cynomys parvidens .................................................................. 54

\section{D}

Deer, Chihuahua mule ….................................................................. 20

Deer, mule .............................................................................. 19

"Deer tiger" :-_...................................................................................... 107

Deer, Western white-tailed ........................................................... 15

Deer, Map of distribution of Western white-tailed..................... 16

Desert harvest mouse ........................................................................... 67

Desert wood rat ................................................................. 70,71

Dipodomyinae ................................................................................ 86

Dobson's shrew …............................................................. 152-154

Dusky shrew ............................................................................... 155

Dwarf vole ................................................................................... 76

E

Economic status of various mammals ...................................... 5-7

Elegant spermophile ……............................................................... 49

Elk …..................................................................................... 12

Elk, Map of distribution ................................................................. 13

Engelhardt marmot ............................................................................ 57

Erethizon epixanthum .................................................................... 90

Erethizontidad ................................................................................... 90

Erethizontinae ................................................................................ 90

Eutamias amoenus operarius .................................................... 40

Eutamias dorsalis utahensis ........................................................ 37

Eutamias hopiensis ............................................................................... 36

F

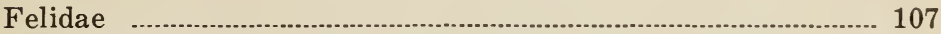

Felis canadensis ....................................................................... 110

Felis hippolestes ........................................................................ 107

Felis uinta ..................................................................................... 111

Fiber zibethicus mergens …………….................................... 79,81

Fiber zibethicus osoyoosensis …............................................ 78-80

Field mouse, Rowley ….......................................................... 66

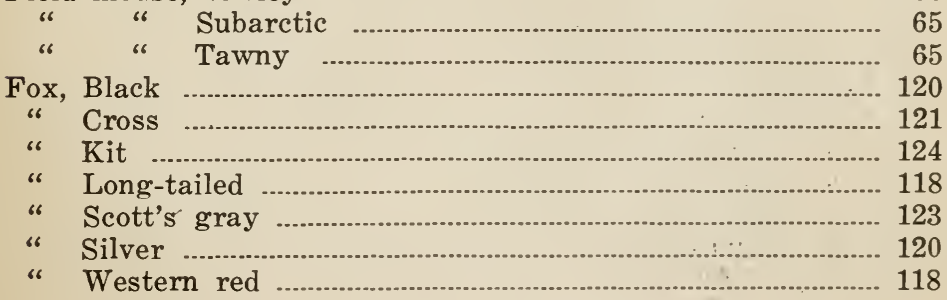


Geomyidae ……....................................................................... 81

Gila chipmunk ........................................................................... 35

Glires, Economic value of ................................................................ 6

Glutton …............................................................................................. 139

Golden breasted canyon mouse ...........................................-........ 66

Golden breasted mouse ................................................................... 66

Golden-mantled marmot ……..................................................... 58

Gopher, Colorado pocket ........................................................... 84, 85

“ Green river pocket ............................................................... 83

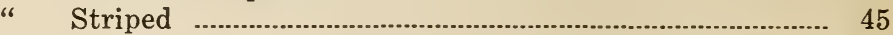

“ Swift ........................................................................................ 83

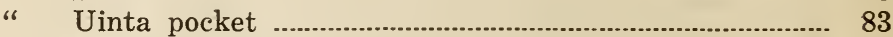

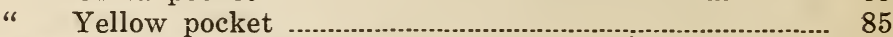

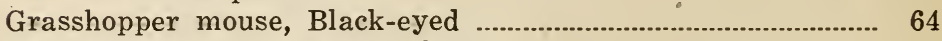

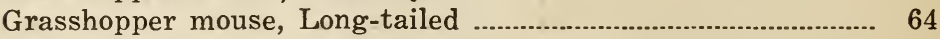

Gray wolf .................................................................................... 114

Great Basin pocket mouse ............................................................ 89

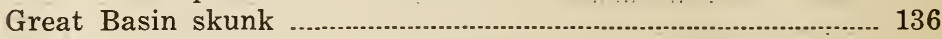

Great northern bat ..................................................................... 165

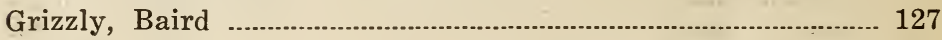

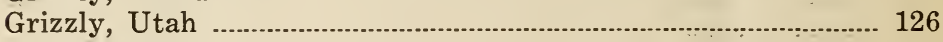

Groundhog …………......................................................................... 58

Ground Squirrel, Say .................................................................... 46

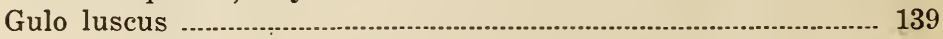

H

Harvest mouse, Aztec ……..................................................... 69

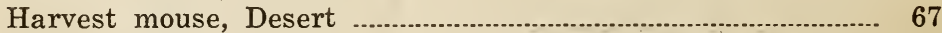

Heteromyidae ............................................................................ 86

Hoary bat ........................................................................... 164-166

Hoary marmot ....................................................................... 57

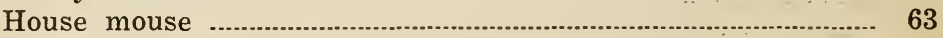

I

Insectivora

$\mathbf{J}$

Jack rabbit, Colorado desert ................................................. 105

Jack rabbit, Western White-tailed (Map) …..................... 100, 101 K

Kangaroo rat ...................................................................................... 86

Kennicott spermophile ............................................................... 48

L

Lasionycteris noctivagans …....................................................... 159

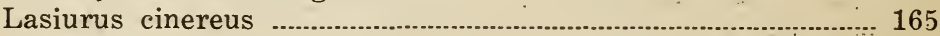

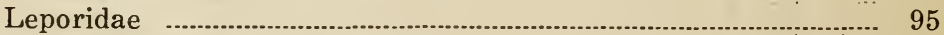

Lepus bairdi ........................................................................... 103-104

" californicus deserticola ........................................................ 105

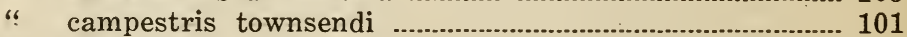

Little brown bat ..................................................................................... 163

Little California bat ..................................................................... 162 
L-(Continued)

Long-eared bat 165

Long-footed kangaroo rat .............................................................. 87

Long-tailed grasshopper mouse ..................................................... 64

Long-tailed pocket mouse ............................................................. 90

Lutra canadensis conora ......................................................... 150

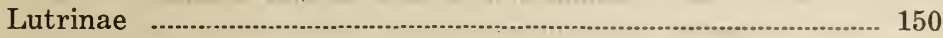

Lynx baileyi .................................................................................... 111

Lynx, Bailey's ................................................................................ 111

Lynx, Canada ................................................................................ 110

Lynx, Uinta mountains ................................................................ 111

M

Mạmalia .......................................................................................... 1

Marmota flaviventris engelhardti ..................................... 56, 57

Marmota flaviventris nosophora ........................................... 56, 58

Marmot, Engelhardt ....................................................... 56, 57

Marmot, Golden mantled ...................................................... 56, 58

Marten, Rocky mountain ................................................................. 142

Masked shrew ........................................................................ 152-153

Mephitis occidentalis major .......................................................... 136

Mexican otter ..................................................................................... 150

Microtus montanus ............................................................... 7, 75

“ montanus rivularis ................................................... 75

" mordax ........................................................................... 77

“ nanus ............................................................................. 76

“ pauperrimus ....................................................................... 78

“ pennsylvanicus modestus ................................................. $\quad 16$

“ richardsoni macropus .................................................. 78

Mink ....................................................................................... 146-147

Minks as rat destroyers ......................................................... 63

Moki kangaroo rat ................................................................................ 87

Moose, Distributional Map .......................................................... 9

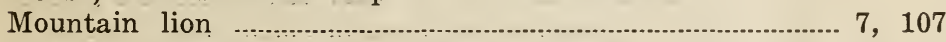

Mountain sheep ............................................................................ 26

Mountain sheep, map .................................................................... 28

Mountain weasel ................................................................................ 144

Mountain wild cat .................................................................... 111

Mouse, Aztec harvest ................................................................ 68, 69

“ Black-eyed grasshopper ..................................................... 64

“ Black-browed mole ............................................................. 64

“ Desert harvest .......................................................... 67, 68

“ House ................................................................................... 63

، Golden breasted ..................................................................... 66

“ Golden breasted canyon ...................................................... 66

“ Great Basin pocket ......................................................... 89

“ Long-tailed grasshopper ................................................. 04

“ Long-tailed pocket ...................................................... 90

“ Nevada pocket ................................................................... 88

“ Rowley cliff ....................................................................... 66

، Subarctic field .................................................................. 65

“ Tawny field ........................................................................ 65

“ True's ........................................................................ 6 "7 
M-(Continued)

Mouse, True's deer ..................................................................... 67

“ Yavapai pocket .................................................................. 87

Mule deer ........................................................................................ 19

Mule deer, Map of distribution of.............................................. 18

Muridae ...................................................................................... 62

Mus musculus ............................................................................. 63

Mus norwegicus ............................................................................ 62

Mus rattus ....................................................................................... 62

Muskrat, Rocky Mountain ...................................................... 78-80

“ Nevada ......................................................................... 81

Mustela caurina origenes ......................................................... 143

Mustelinae ................................................................................. 139

Myotis californicus ...................................................................... 162

" evotis ......................................................................... 165

" lucifugus longicrus .................................................. 163

" yumanensis ................................................................. 158

$\mathbf{N}$

Navigator shrew

$156-157$

Neotoma cinerea .......................................................................... 73

" "

" ، orolestes .................................................... 74

Neotoma desertorum ................................................................... 71

Neotominae ....................................................................... 7, 71

Norway rat .............................................................................. 62

Nevada muskrat ......................................................................... 81

Nevada pocket mouse .................................................... 156, 157

O

Ochotona bedfordi ..................................................................... 93

Ochotona cinnamomea ..................................................................... 92

“ schisticeps fuscipes ................................................. 94

“ uinta ....................................................................... 93

Ochotonidae ............................................................................... 92

Odocoileus hemionus canus .......................................................... 20

Odocoileus virginianus macrourus ................................................ $\quad 15$

Odontocoelus hemionus .............................................................. 19

Onychomys longicaudus ......................................................... 7, 64

Onychomys melanophrys ............................................................. 64

Otter, Mexican ............................................................................. 150

Ovis cervina ........................................................................................ 26

P

"Painter" ....................................................................................... 107

Panamint pocket mouse ............................................................ 88

"Panther" ......................................................................................... 107

Parowan pika .................................................................................. 94

Peale vole ........................................................................................... 75

Perodipus longipes ................................................................... 87

“ montanus utahensis .................................................. 86

Peromyscus boyleii rowleyi ......................................................... 66

Peromyscus crinitus auripectus ................................................. 66 
Peromyscus rufinus ................................................................... 65

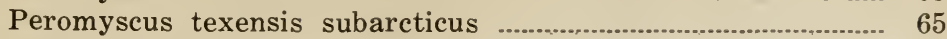

Peromyscus truei ............................................................................ 67

Perognathus flavus bimaculatus ................................................... 87

Perognathus panamintinus ............................................................... 88

Perognathus nevadensis .............................................................. 88

“ panamintinus ....................................................... 88

Pigmy vole parvus olivaceus ......................................................

Pika ................................................................................................ 92-94

Pipistrellus hesperus .................................................................. 161

Pituophis catenifer deserticola ..................................................... $\quad 75$

Pocket gopher, Green river .............................................................. 83

، " Swift ......................................................................... 83

"6 " Uinta $\ldots$......................................................................... 83

Pocket mouse, Apache .................................................................... 88

“ " Great Basin ....................................................... 89

“ “ Nevada ...................................................................... 88

“ “ Panamint .................................................................... 88

“ “ Yavapai ....................................................................... 87

Porcupine, Western ............................................................ 7, 90

“ Yellow haired ........................................................... 90

Prairie-dog, white-tailed ............................................................. 52

Prairie-dog, white-tailed (Map) ................................................ 53

Procyon lotor mexicanus ........................................................... 133

Prong horn antelope ....................................................................... 24

Puma ........................................................................................................ 107

Putorius arizonensis ................................................................... 144

Putorius vison ...................................................................... 146-149

Putorius vison lutreocephalus .............................................. 146-149

R

Rabbit, Colorado desert jack ................................................... 105

“ Rocky Mountain snowshoe ...................................... 103-104

“ Western white tailed jack ........................................ 101

Racoon-fox ....................................................................................... 131

Racoon ............................................................. 8, 132 (Map) 133

Rat, Arizona wood ............................................................... 74, 72

" Black ...................................................................................... 62

" Brown ............................................................................................... 62

“ Cinnamon bushy-tailed wood ................................................. 74

“ Desert wood ................................................................... 70-71

“ Gray bushy-tailed wood ...................................................... 73

“ Kangaroo ................................................................................ 86

“ .Long footed kangaroo ............................................................ 87

“ Norway ...................................................................................... 62

Rattlesnake ....................................................................................... 75

Reithrodontomys megalotis aztecus .......................................... 69

Reithrodontomys megalotis megalotis ................................ 67, 68

Related chipmunk .................................................................. 39

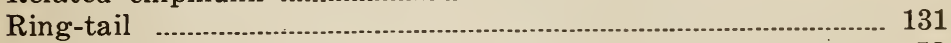

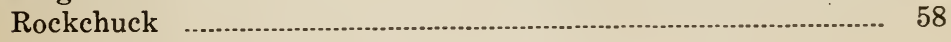


R-(Continued)

Rock squirrel ............................................................................. 50

Rock spotted skunk ....................................................................... 137

Rocky Mountain marten .................................................... 142-143

Rocky Mountain muskrat .......................................................... ґ४

Rocky Mountain snowshoe rabbit ......................................... 103-104

Rodentia ...................................................................................... 33

Rowley Cliff mouse ..................................................................... 66

Rowley field mouse .......................................................................... 66

Rupicaprinae .......................................................................... 26

Sawatch vole ........................................................................................... 76

Say ground squirrel ........................................................................... 46

Sciuridae ............................................................................................... 33

Sciurinae ................................................................................................ 33

Sciurus fremonti ................................................................................. 35

Sciurus hudsonius ventorum ......................................................... 33

Shrew, Dobson's ...................................................................... 152-154

“ Dusky ........................................................................................ 155

“ Masked ................................................................................. 154

“ Navigator ........................................................................ 157

Silver-haired bat ..................................................................................... 59

Skunks as rat destroyers ............................................................... 63

Skunk, Great Basin ....................................................................... 136

“ Rock spotted ........................................................t................... 137

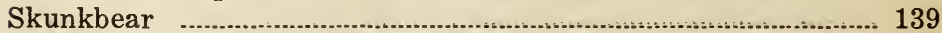

Snakes, Desert gopher ......................................................................... $\quad 75$

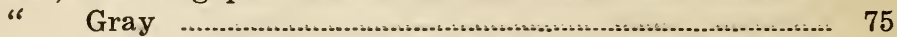

“ Pacific garter ....................................................................... 75

، Red barred ......................................................................... 75

“ Wandering garter ........................................................ 75

Snowshoe rabbit, Rocky Mountain ......................... 103 (Map) 104

Sonoran Beaver ................................................................................ 61

Sonoran Beaver (Map) .................................................................... 60

Sorex dobsoni .................................................................................. 153

Sorex obscurus ................................................................................. 155

Sorex personatus ...............................................sıt....................... 152-154

Soricidae ................................................................................. 1;53

Soricinae ................................................................................................... 153

Spermophile, Armed .............................................................. 49

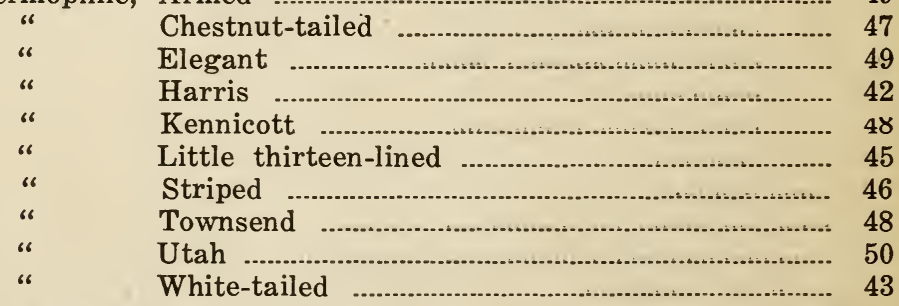

Spilogale gracilis saxatilis ....................................................... 137-8

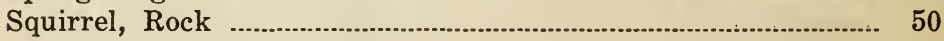




\section{S-(Continued)}

Striped spermophile .......................................................................... 46

Subarctic field mouse ........................................................................ 65

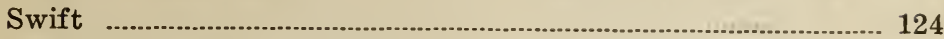

Sylvilagus auduboni baileyi............................................................. 95

“ Warreni .................................................................... 97

“ Nuttalli grangeri ….................................................... 97

$\mathbf{T}$

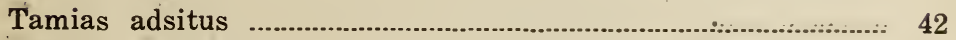

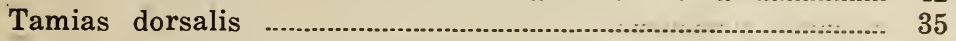

Tamias lectus ........................................................................ 41

Tamias minimus consobrinus ..................................................... 39

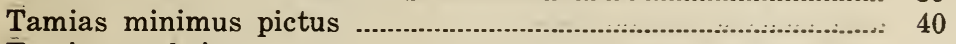

Tamias umbrinus .................................................................. 38

Tawny field mouse .................................................................... 65

Taxidea taxus ........................................................................... 135

Thamnophis sirtalis parietalis ....................................................... $\quad 75$

ordinoides elegans ……............................................. 75

Thomomys ocius ............................................................................. 83

" fossor .............................................................................. 85

“ perfaliidus aureus ......................................................... 85

“ uinta ............................................................................ $8 \dot{3}$

Townsend spermophile .......................................................................... 48

True's bat ................................................................................................ 163

True's mouse ..................................................................................... 67

\section{$\mathbf{U}$}

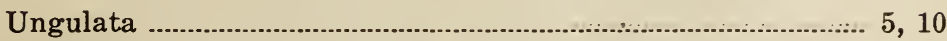

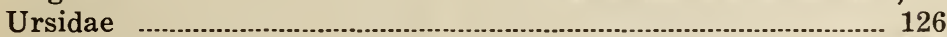

Ursus americanus .................................................................... 130

Ursus horribilis bairdi ....................................................................... 127

Ursus utahensis …................................................................... 126

Úrocyon cinereo-argenteus scotti ................................................. 123

Utah grizzly .................................................................................. 126

Utah Kangaroo Rat ........................................................................ 86

Utah meadow vole .................................................................................. 75

Utah prairie dog ............................................................................. 54

Utah spermophile ................................................................................... 50

V

Vespertilio fuscus ............................................................................. 161

Vespertilionidae ................-............................................................ 158

Vespertilioninae ............................................................................ 158

Vole, Big-footed ................................................................................. 78

“ Cantankerous ….................................................................. 77

“ Dwarf ....................................................................................... 76

“ Peale ........................................................................................ 75

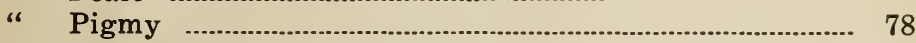

“ Sawatch ........................................................................................ 76

“ Utah meadow .................................................................... 75 
V-(Continued)

Vulpes fulva macroura ................................................................. 118

" " argentata .............................................................. 120

“ fulvus decussatus .......................................................... 121

، velox .................................................................................... 124

W

Wapiti ................................................................................................. 12

Wasatch chipmunk ....................................................................... 39

Weasel, Mountain ............................................................................ 144

Weasels as rat destroyers ............................................................. 63

Western bat .................................................................................... 161

Western porcupine .......................................................................... 90

Western white-tailed deer ............................................................... 15

Western white-tailed jack rabbit ................................................ 101

White-tailed prairie dog ............................................................... 52

Wild cat, Mountain ........................................................................... 111

Wind river mountains chickaree .................................................... 33

Wolf .......................................................................................... 7, 114

Wolverine .............................................................................................. 139

Woodchuck ......................................................................................... 56-58

Wood Rat, Arizona ............................................................................ 74

" “ Cinnamon bushy-tailed .............................................. 74

“ “ Desert ................................................................ 70, 71

“ “ Gray bushy-tailed ....................................................... 73

Wyoming cottontail .................................................................. 95

Y

Yavapai Pocket mouse ................................................................. 87

Yellow-haired porcupine ..................................................................... 90

Yellow pocket gopher ...................................................................... ${ }^{-} 85$

Z

Zuni Prairie dog ........................................................................... 55

" " " (Map) ......................................................... 53 


\section{BULLETIN OF THE UNIVERSITY OF UTAH}

\section{Vol. 12}

April, 1922

Number 15

Entered as second-class matter, June 16, 1906, at the post office at Salt Lake City, Utah, under Act of July 26, 1891. Published quarterly. Published by the University, Salt Lake City. 


\section{Date Due}

All library items are subject to recall at any time.

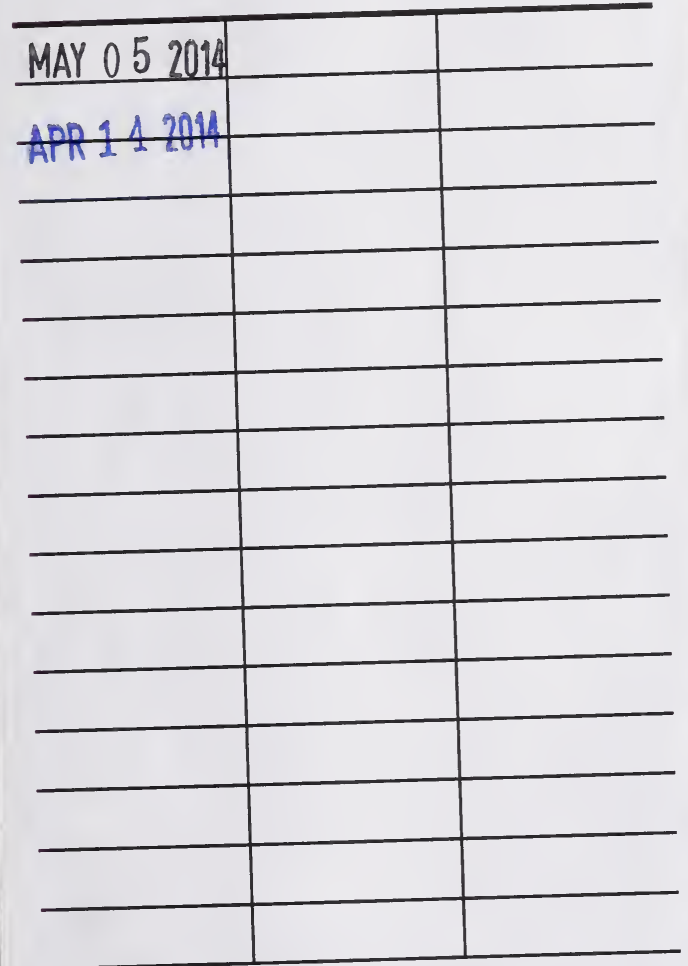

Brigham Young University 


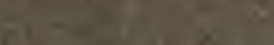

$=$

H.

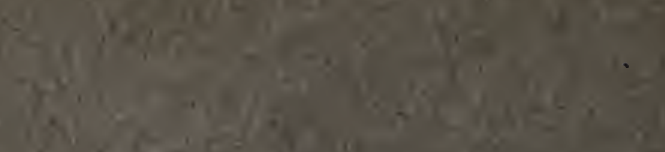

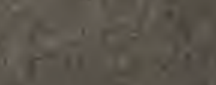

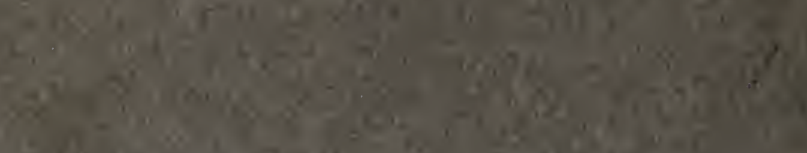

$6 x^{-625}$

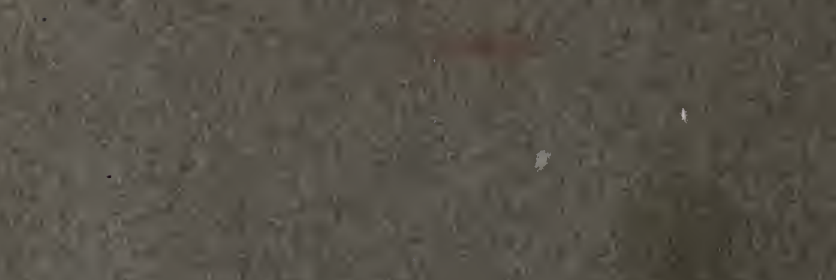

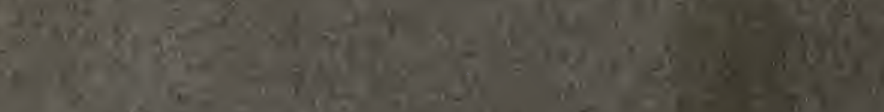

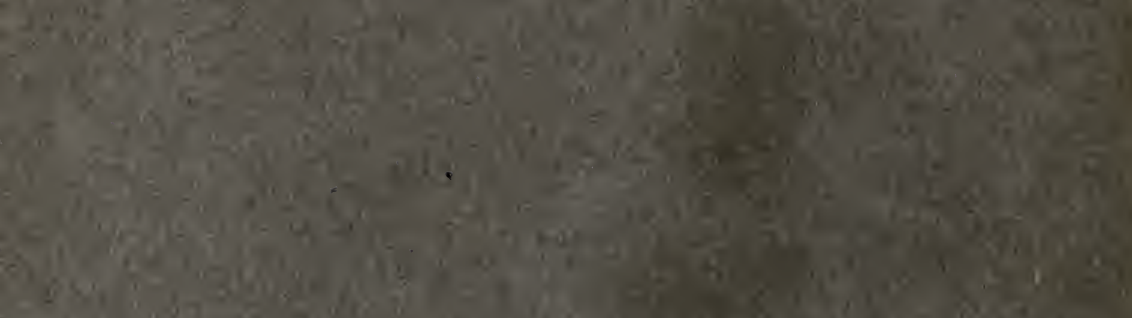
(4) $\operatorname{lin}^{2}\left(\frac{1}{2}\right.$

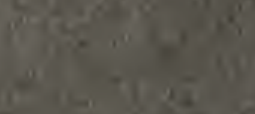

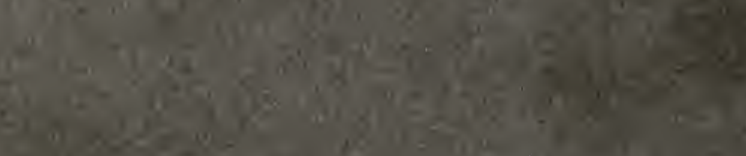

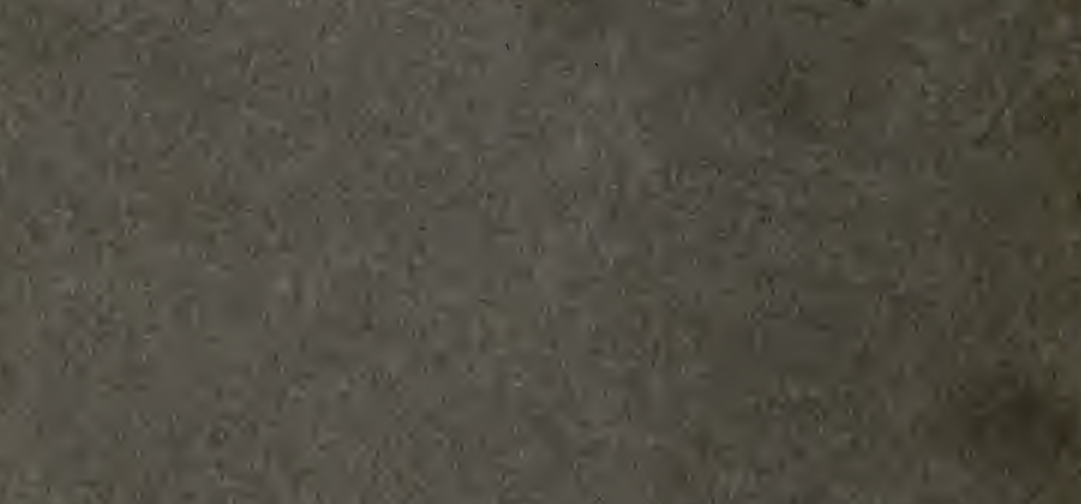

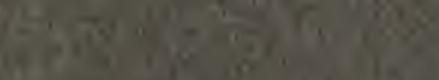

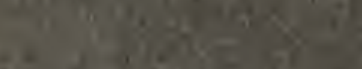

